HAROLDO FRANÇA REBOUÇAS NETO

Auto-Tune e Humor no Youtube 


\section{Auto-Tune e Humor no Youtube}

\section{Versão Original}

Dissertação apresentada à Escola de Comunicação e Artes da Universidade de São Paulo, para obtenção do Título de Mestre em Meios e Processos Audiovisuais.

Área de Concentração: Poéticas e Técnicas

Orientadora: Profa. Dra. Patricia Moran Fernandes 
Nome: NETO, Haroldo França Rebouças

Título: Auto-Tune e Humor no Youtube

Dissertação apresentada à Escola de Comunicação e Artes da Universidade de São Paulo, para obtenção do Título de Mestre em Meios e Processos Audiovisuais.

Aprovado em:

\section{Banca Examinadora}

Prof.(a) Dr.(a)

Instituição:

Julgamento:

Prof.(a) Dr.(a)

Instituição:

Julgamento:

Prof.(a) Dr.(a)

Instituição:

Julgamento: 


\section{RESUMO}

Esta dissertação intenciona investigar a construção do cômico, mediado pela tecnologia, em vídeos remix publicados na plataforma YouTube. Os trabalhos analisados propõem o riso a partir da manipulação de tempo e pitch do áudio de vídeos virais, possibilitada por softwares como Auto-Tune e Melodyne. Entendemos remix conforme autores como Lev Manovich, Eduardo Navas e Lawrence Lessig, que afirmam que vivemos em uma "Cultura Remix", uma época que tem como base cultural o sampling, atividade que consiste na troca inteligente entre fragmentos de diversas mídias. Analisaremos a emergência do riso nesse contexto, a partir de reapropriações de materiais preexistentes na rede. Autores como Henri Bergson e Michail Bakhtin nos fornecem o suporte conceitual para investigarmos o riso como um recurso dramático e da cultura tanto na vida cotidiana quanto nas plataformas digitais, que facilitaram, por um lado, o acesso e reciclagem de "detritos midiáticos", e, por outro, potencializaram as possibilidades de manipulação desses materiais.

Palavras chaves: cultura remix, riso, youtube, auto-tune, melodyne, carnavalização. 


\section{ABSTRACT}

This dissertation intends to investigate the construction of the comic, mediated by technology, in video remix published on the YouTube platform. The analyzed works propose the laughter from the manipulation of time and pitch of the audio of viral videos, made possible by softwares like Auto-Tune and Melodyne. We understand remix by authors such as Lev Manovich, Eduardo Navas and Lawrence Lessig, who claim that we live in a "Culture Remix", an era that is based on cultural sampling, an activity that consists of the intelligent exchange between fragments of various media. We will analyze the emergence of laughter in this context, from re-appropriation of pre-existing materials in the network. Authors such as Henri Bergson and Michail Bakhtin provide us with conceptual support for investigating laughter as a dramatic and cultural resource in everyday life as well as on digital platforms that facilitated access to and recycling of "media debris" on the one hand, and, on the other, potentialized the possibilities of manipulation of these materials.

Keywords: culture remix, laughter, youtube, auto-tune, melodyne, carnivalization. 


\section{LISTA DE ILUSTRAÇÕES}

Figura 1: Trecho do remix "Top", do canal Viradrop

Figura 2: Página inicial do YouTube a partir de 2014

Figura 3: Trecho do remix do vídeo "Bambam Enlouquecendo / Bambam Bodybuilder", do canal Viradrop

Figura 4: Interface do Auto-Tune

Figura 5: Interface do Melodyne

Figura 6: Trecho do remix "Senhora", do canal Timbu Fun

Figura 7: Trecho do remix "Senhora", do canal Timbu Fun

Figura 8: Trecho do remix "Olha eu com boné", do canal Viradrop

Figura 9: Trecho do remix "Olha eu com boné", do canal Viradrop

Figura 10: Trecho do remix "Tô cagado de fome", do canal Viradrop

Figura 11: Trecho do remix "Quero café", do canal Timbu Fun

Figura 12: Trecho do remix "Saudação à mandioca", do canal Timbu Fun

Figura 13: Trecho do remix "Eu sou o Dougras", do canal Atilakw

Figura 14: Trecho do remix "Tô cagado de fome", do canal Timbu Fun

Figura 15: Trecho do remix "Acertou, miserável", do canal Atilakw

Figura 16: Trecho do remix "Guitarra Humana", do canal Atilakw

Figura 17: Trecho do remix "Arrocha do Falsete", do canal Timbu Fun

Figura 18: Trecho do remix "Esse programa aqui tá uma poha", do canal Viradrop

Figura 19: Trecho do remix "Sou Faraó", do canal Viradrop

Figura 20: Trecho do remix "Eu comi seu batom", do canal Atilakw

Figura 21: Trecho do remix "Quero café", do canal Viradrop 
Figura 22: Trecho do remix "Bambam enlouquecendo", do canal Viradrop

Figura 23: Trecho do remix "Coé rapaziada", do canal Viradrop

Figura 24: Trecho do remix "Choque da uva", do canal Viradrop

Figura 25: Trecho do remix "O que você lanchou?", do canal Timbu Fun

Figura 26: Trecho do remix "Olá, Marilene", do canal Viradrop

Figura 27: Trecho do remix "Estocando o vento", do canal Timbu Fun

Figura 28: Trecho do remix "Bambam Bodybuilder", do canal Atilakw

Figura 29: Trecho do remix "Top", do canal Viradrop

Figura 30: Trecho do remix "O céu tem pão?", do canal Viradrop

Figura 31: Trecho do remix "Seu buceta", do canal Viradrop

Figura 32: Trecho do remix "Magrelinho", do canal Atilakw

Figura 33: Trecho do remix "Errou", do canal Viradrop

Figura 34: Trecho do remix "'Cepo de Madeira", do canal Timbu Fun

Figura 35: Trecho do remix "Estocando o Vento", do canal Timbu Fun

Figura 36: Trecho do remix "The Voice Dog”, do canal Timbu Fun

Figura 37: Trecho do remix "The Voice Dog", do canal Timbu Fun

Figura 38: Trecho do remix "Tu é louca", do canal Atilakw

Figura 39: Trecho do remix "Sé loco Cachuera", do canal Viradrop

Figura 40: Trecho do remix "Ar condicionado", do canal Timbu Fun

Figura 41: Trecho do remix "Chama a Mamãe, Ketlyn", do canal Atilakw 
SUMÁRIO

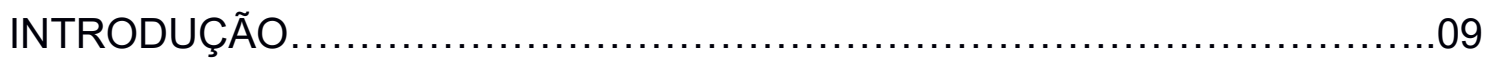

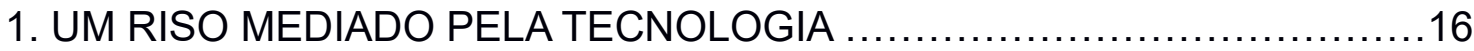

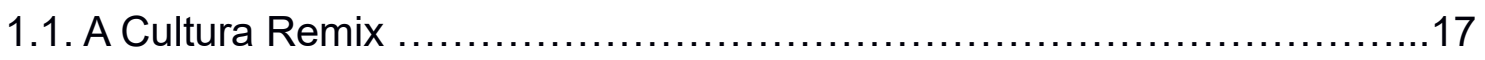

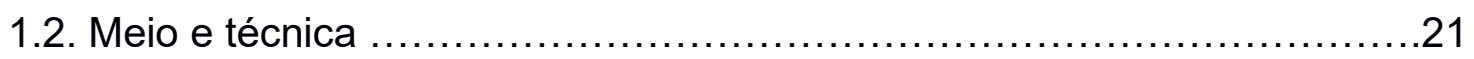

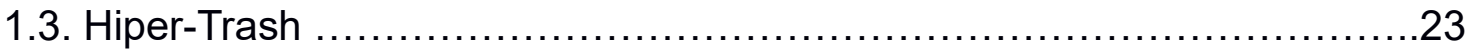

1.4. Semiosfera, ludosfera, memesfera …...............................26

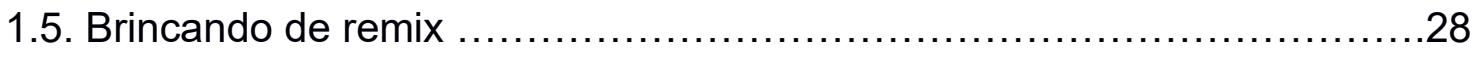

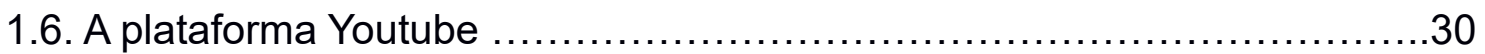

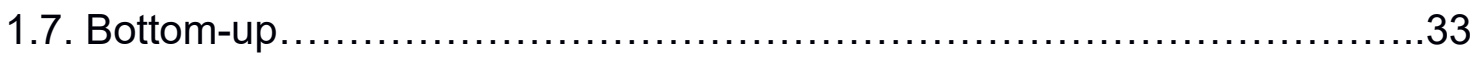

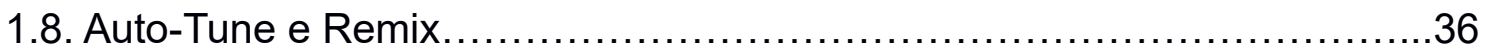

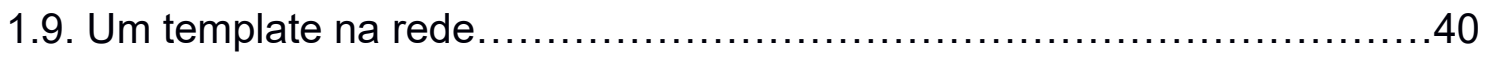

2. O RISO NAABERTURA DE JANELAS ...................................42

2.1. Audiovisual do Cotidiano .....................................................

2.2. Uma atitude Carnavalizante...........................................4

2.3. O grotesco e o insociável................................................ 49

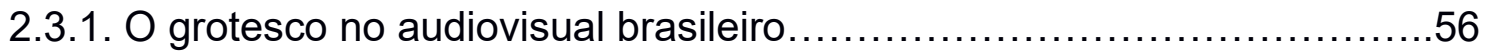

2.4. Bissociação e justaposição.....................................................59

2.5. A escolha do gênero musical.......................................62

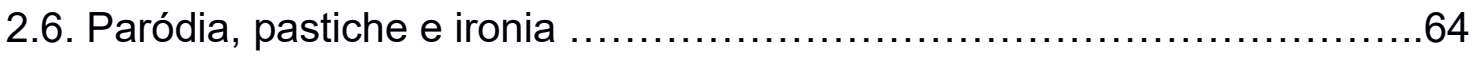

3. O CÔMICO A PARTIR DE COLISÕES..........................................66

3.1. Entre estado de espírito da personagem e arranjo sonoro .................78

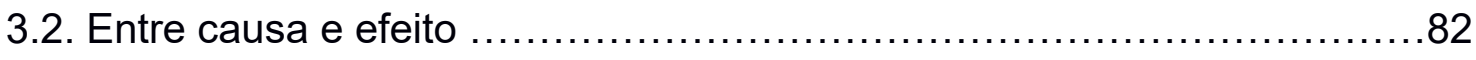

3.3. Por coincidência a partir de fala ou ação.................................... 84

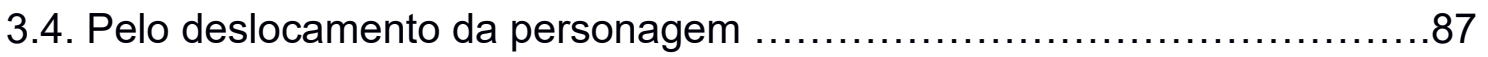


3.4.1. Pelo encontro da personagem consigo mesma......................90

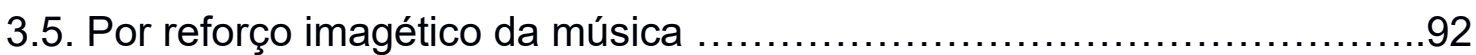

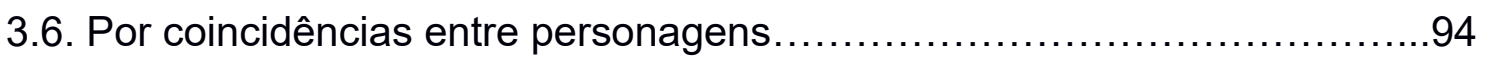

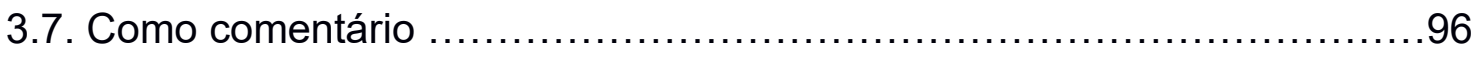

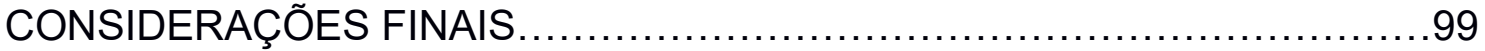

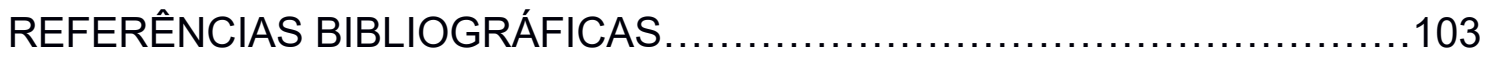




\section{INTRODUÇÃO}

Com o surgimento do YouTube em 2005 e, treze anos depois, com seus mais de um bilhão de usuários, o vídeo online se tornou onipresente na nossa cultura audiovisual, nos mais diversos meios. Produzimos, consumimos e compartilhamos esse tipo de material em diversas plataformas, diariamente. Webséries, críticas, comédia, esportes, músicas e vários outros formatos possíveis formam um universo cultural gigantesco. Nesse contexto, é cada vez mais comum a produção independente de conteúdo: vídeos caseiros, vlogs, filmagens de shows, tutoriais, etc. No presente trabalho, o foco será em um tipo específico de linguagem: o vídeo remix.

O termo "remix" é comumente descrito como uma técnica específica de reciclagem de produtos culturais preexistentes. Como exemplos, podemos citar o remix musical, que usa do arranjo vocal da música original para criar uma outra música; reapropriação de tendências no campo da moda, referências em obras arquitetônicas; redublagens e montagens em vídeo. Em todos esses casos, existe um fragmento, extraído de um "original", e a sua inserção em outro contexto.

Quando, mesmo por acidente, deixamos um vídeo sendo executado sem som, enquanto ouvimos uma música qualquer e nos surpreendemos com coincidências entre som e imagem, estamos fazendo remix. Quando visitamos um brechó em busca de acessórios antigos, para recombiná-los com nossas roupas atuais, também estamos remixando. Se salvamos uma imagem divertida na galeria de mídias do smartphone e a usamos como comentário na postagem de um amigo em uma rede social, idem. O remix pauta muitas de nossas relações na vida contemporânea.

Como veremos adiante, apoiados em Eduardo Navas (2012), as ações de copiar/recortar e colar, tão comuns em nossa relação com o computador, também se dão em nossa relação uns com os outros e com o mundo. O autor denomina essa atividade como sampling. Desde que começamos a entender o mundo, na infância, "sampleamos" comportamentos, ideias, imagens e mídias em geral.

Ao longo da dissertação, olhamos para o mundo a partir da Cultura Remix, segundo autores como Manovich (2007), Navas (2012) e Lessig (2008). Pretendemos dar continuidade ao empreendimento já realizado por diversas pesquisas, no sentido de compreender melhor as relações que se estabelecem 
na web, considerando os meios digitais e a construção de memes. O termo "meme" foi cunhado por Dawkins (1996) como uma unidade mínima de informação, que tal qual o gene, seu equivalente biológico, seria capaz de se multiplicar e sofrer mutações.

A definição de Dawkins foi importante para iniciar as discussões sobre os memes de hoje, mas usaremos um conceito atualizado por outros pensadores, como Fontanella (2009), para quem o meme tem uma definição mais próxima do senso comum, ou seja, a reprodução de um "viral" com alguma modificação. Usaremos o termo "viral" para nos referir a materiais que são amplamente compartilhados na rede, a ponto de se tornarem conhecidos pela opinião pública de alguns grupos sociais.

Feita essa breve contextualização sobre a cultura remix, passemos à construção de nosso problema de pesquisa. Quando iniciamos, pretendíamos compreender a maneira como a cultura remix se manifestava nos canais brasileiros Atilakw ${ }^{1}$, Timbu Fun ${ }^{2}$ e Viradrop ${ }^{3}$. Porém, com o decorrer do processo, entrando em contato com os referenciais teóricos, percebemos que nossa questão era mais específica, e tinha algo a ver com a relação entre o riso e a tecnologia.

Pela nossa vivência e experiência na elaboração de comédias para teatro e na elaboração de vídeos remix, nos deparamos com questões como: o que faz uma música ser cômica? Ou então: que "confrontos" podemos estabelecer em montagens de vídeo, que sejam potencialmente cômicos? Já percebíamos que haviam diversos aspectos a levarmos em consideração. Ao analisar o trabalho de outros artistas, era recorrente o riso a partir da contradição entre elementos colocados em justaposição. Por exemplo, o vídeo "Gaiola das Cabeçudas", elaborado pelo programa "Comédia MTV", propõe um funk, estilo culturalmente ligado a temas relacionados ao sexo, mas com uma letra voltada para questões ligadas a intelectualidade e teorias acadêmicas. Nesse caso, o título fazia referência ao grupo "Gaiola das Popozudas", deslocando os assuntos em questão do sexual para o intelectual. Exemplos como esses nos levaram a pensar que, para propor o riso, seria interessante "trair" a expectativa do espectador com soluções e desfechos inesperados.

1 Disponível em: https://www.youtube.com/user/atilakw

2 Disponível em: https://www.youtube.com/timbufun

3 Disponível em: https://www.youtube.com/channel/UCCjJ6nzg3-74FbISqmE_EcA 
Essa noção de confronto também se apontou quando percebemos diversos remix que já assistíamos, e outros que produzíamos, levando em consideração a origem dos fragmentos selecionados. Por exemplo, no remix "E se The Beatles cantasse É o Tchan ${ }^{4}$ ?", elaborado pelo canal Montagensgabrielcx, podemos ver a banda britânica cantando e dublando sucessos da banda de axé brasileira. Em uma linha de raciocínio semelhante, o canal Superxarque elaborou uma série de vídeos intitulados "Xarque Zone ${ }^{5 "}$, que exibem cantoras pop como Beyoncé, Madonna e Britney Spears dançando em ritmo de tecnobrega.

Exemplos como esse já indicavam, para nós, possíveis caminhos para a construção do cômico. Sentimos, então, a necessidade de nos aprofundar nesse tema e em suas possibilidades. Percebemos, ao longo da pesquisa, que é impossível determinar ou prever os mecanismos do riso, até porque estes estão intimamente conectados com a cultura e visão de mundo de cada um.

A opção por analisar meios audiovisuais também se deu pela vivência do pesquisador enquanto internauta e videomaker, o que possibilitaria a ocupação de um lugar de pesquisa participante. Isso possibilitou que assistíssemos todos os remix diversas vezes, enquanto entrávamos em contato com os referenciais teóricos, o que nos possibilitou revisitar os trabalhos analisados sob diversos pontos de vista, como o do riso.

Um dos primeiros autores com os quais entramos em contato foi Bergson (1983), que nos traz uma análise contundente sobre os possíveis mecanismos por trás do cômico. Não consideramos as ideias desse autor como verdades absolutas, mas seu construto foi imprescindível para acender as nossas inquietações acerca do tema, bem como compreendê-lo:

Quem se isola expõe-se ao ridículo, porque o cômico se constitui, em grande parte, desse próprio isolamento. Assim se explica que a comicidade seja muitas vezes relativa aos costumes, às idéias - sejamos francos, aos preconceitos de uma sociedade (BERGSON, 1983, p. 66).

Tivemos contato, então, com vídeos que utilizavam do Auto-Tune e Melodyne para produzir efeitos risíveis a partir da manipulação vocal em vídeos virais. Tratam-se de softwares criados para a correção sonora na fase de pósprodução de gravação de música profissional. Eles tornam possível corrigir a 
afinação da voz de um cantor ou mesmo de um instrumento que não tenha entrado no "tom" correto da música.

Realizamos uma busca por títulos, trabalhos em língua portuguesa que abordem o uso de softwares como esses em poéticas e técnicas audiovisuais, no contexto do remix, e ligados ao riso, porém não foram encontrados resultados afins. Foi possível encontrar apenas estudos sobre o seu uso corrente na indústria Pop, além de pesquisas sob o viés da tecnologia. Contudo, nesta pesquisa percebemos que o riso não está ligado às particularidades técnicas desses softwares, e sim ao uso que é feito deles. Foram desenvolvidos com um objetivo específico, ligado à pós-produção musical, mas sua função foi subvertida pelos usuários, para a elaboração do cômico.

O riso, nos vídeos que analisamos, é construído pela criação artificial de canções que brotam no seio dos vídeos originais. Percebemos que é nesse brotar que se localizaria nosso objeto de pesquisa: o cômico construído a partir da alteração de vídeos já existentes. Esses vídeos, selecionados pelos remixers, possuem as mais variadas fontes. Então, identificamos a existência de um template, ou seja, um formato mais ou menos consolidado, a partir do lançamento, em 2008, de alguns video remix pelo canal americano Schomoyoho6 ${ }^{6}$. De 2014 até os tempos atuais, canais brasileiros como Atilakw, Timbufun e Viradrop se apropriaram dessa "fórmula", que consiste na criação de music videos a partir de vídeos diversos.

Selecionamos, então, todos os vídeos publicados por esses três canais até julho de 2018, para identificar, entre eles, linhas de raciocínio em comum, articulações entre fragmentos e diversos outros aspectos ligados à elaboração do cômico. Ao fazer o recorte levando em consideração vídeos cuja realização só é possível por meio da mediação tecnológica dos softwares mencionados, nos perguntamos: nos remix que seguem esse template, de que maneira o cômico é construído? Acreditamos que a tentativa de responder essa pergunta nos aproxima de nosso interesse de entender melhor as relações entre riso e tecnologia, a partir dessa especificidade.

É importante esclarecer que este não é um trabalho sobre recepção e sim criação. Nossa investigação foi no sentido de compreender princípios e lógicas contidas na elaboração dos remix. Para entender melhor como esses

6 Disponível em: https://www.youtube.com/user/schmoyoho 
conceitos e ideias se articulam na presente pesquisa, passemos agora para a descrição dos capítulos e outras questões metodológicas.

No primeiro capítulo, nosso foco será a internet. Percebemos que antes de abordar os mecanismos do humor, precisaríamos entender que transformações foram provocadas pela inserção das tecnologias de informação e comunicação (TIC), especialmente em meios digitais, como smartphones, tablets e computadores pessoais. A internet será pensada como espaço de remediação, em termos de Bolter e Gruisin (2000), que se transformou em espaço de comunicação de distintos sujeitos, sejam eles amadores ou profissionais do audiovisual. Nosso trabalho priorizou amadores. Mergulhamos na internet como espaço de produção e criação de valores, de trocas horizontais. Para tal, dialogamos com autores como Bourriaud (2009); Tiezmann e Rossini (2013); Martino (2000); Larizzatti (2013); Burguess e Green (2009) e Felinto (2007), além dos já mencionados.

A criatividade que nos interessará abordar nesse trabalho tem a ver com a reapropriação de mídias com finalidade cômica, como ocorre com os memes. Fontanella (2009) retoma o termo cunhado por Dawkins e propõe a ideia de "memesfera" para designar o "caldo cultural" no qual essas misturas e transformações ocorrem.

Compreender nossa vida online inserida em uma "memesfera" será importante nas páginas seguintes, para pavimentar o caminho pelos quais tentaremos entender os mecanismos do riso na rede. Bergson (1983) nos guiará nesse percurso, esclarecendo que tais mecanismos fazem alusão ao ato de brincar, jogar ou se divertir.

Ainda no primeiro capítulo, descreveremos o site Youtube e sua evolução de um simples repositório de vídeos para uma plataforma de expressão pessoal. Sendo este um meio de comunicação, não será possível analisá-lo apenas sob o viés tecnológico, mas político, social e construído coletivamente. Por fim, descreveremos o funcionamento técnico dos softwares abordados, bem como as transformações que provocaram na indústria do entretenimento.

Após o primeiro capítulo, pavimentando o território virtual no qual o riso ocorre, passaremos ao segundo, no qual o riso estará em foco. Iniciaremos pela análise da matéria prima, ou seja, as mídias escolhidos pelos remixers para a manipulação. 
Depois de nos dedicarmos à análise das características dos vídeos "originais", passaremos à abordagem da atitude dos remixers, a partir do conceito de carnavalização, de Bakhtin (2008). Para isso, precisaremos fazer uma regressão cronológica à Idade Média e encontrar aspectos que se mantém vivos na internet.

É nesse capítulo que traremos mais ideias de Bergson (1983), que oferece importantes caminhos para compreender, ainda que de forma não precisa, os mecanismos do riso. Ele considera a sociedade como uma espécie de máquina, cuja função consiste em manter determinados padrões de comportamento - de acordo com a cultura de cada lugar ou grupo. É esperado que os indivíduos hajam com inteligência e maleabilidade para lidar com o cotidiano. O riso, então, surge como ferramenta de correção para os "defeitos" da máquina.

Nesse capítulo, também exercitaremos o olhar sobre os diferentes modos de pôr em relação diferentes fragmentos, a partir das ideias de montagem, metáfora, paródia e ironia. São diversos pontos de vista sobre o ato de pôr em relação, estabelecer diálogos e confrontos.

A partir de Eisenstein (2002) e Carone (1974), compreenderemos a montagem como a justaposição entre diferentes blocos de significado, que estabelecem entre si relações conceituais e metafóricas. A conexão entre diferentes fragmentos provoca uma correspondência simbólica, gerando efeitos de sentido novos, em relação aos que existiam antes da aproximação provocada pelo remixer.

Após a elaboração desses dois primeiros capítulos, entendemos que já dispúnhamos de um levantamento de informações interessantes para fazer a análise dos vídeos. Então assistimos aos remix diversas vezes, na tentativa de localizar e organizar aspectos relevantes na construção do cômico.

Do ponto de vista metodológico, fizemos uma pesquisa qualitativa, baseada em uma pesquisa bibliográfica e de análise teórica acerca do assunto, tendo como apoio a pesquisa indutiva, através de um estudo de caso que tomou como material todos os vídeos publicados pelos canais Atilakw, Viradrop e Timbu Fun, além da própria experiência de interação do pesquisador no site, como usuário do YouTube e membro dessa comunidade na rede, o que possibilitou uma observação participante. 
Feitas estas considerações iniciais, passemos à compreensão de como se dá a relação entre riso e tecnologia e a construção do cômico nos video remix analisados. 


\section{UM RISO MEDIADO PELA TECNOLOGIA}

Em outubro de 2016, foi publicado na plataforma YouTube ${ }^{7}$ um vídeo de um garoto brasileiro de onze anos ensinando uma brincadeira que consiste em gerar um pequeno estouro usando um palito de fósforo e um martelo. A brincadeira é tradicional em São Paulo das Missões, município do interior do Rio Grande do Sul, onde o vídeo foi gravado.

Em maio de 2017, em outra plataforma, o Facebook $^{8}$, o mesmo vídeo foi difundido pela página South America Memes ${ }^{9}$. A partir de então, a repercussão da brincadeira do garoto ultrapassou os limites do local, alcançando notoriedade global. O garotinho e suas ações se tornaram um objeto de humor. Gugu Gaiteiro, o menino responsável pela gravação do vídeo, se tornou uma figura pública, não apenas pela repercussão do vídeo que compartilhou, mas por incontáveis montagens feitas a partir deste, distribuídas e compartilhadas em diversas outras plataformas e redes sociais.

Atualmente, o vídeo original possui mais de um milhão e quatrocentas mil visualizações e Gugu Gaiteiro já foi convidado para dar entrevistas em diversos programas de televisão e para fazer participações em outros canais do YouTube.

A imagem do garoto foi usada em incontáveis gifs e montagens em imagem estática e vídeo com fins humorísticos. Algumas dessas montagens misturam imagens dessa mídia com outras, de outras fontes, estabelecendo diversas formas de diálogos intertextuais com finalidade cômica.

Em algumas dessas montagens, quando o garoto acerta o prego com o martelo, acontece uma grande explosão. Em outras, o garoto aparece "cantando", graças à manipulações sonoras feitas em softwares como AutoTune e Melodyne. Uma dessas montagens se tornou trilha sonora de um jogo desenvolvido para a plataforma Android"10, que possui o vídeo "Cepo de Madeira" como mote ${ }^{11}$. Nesse jogo, o aspecto lúdico da brincadeira é adaptado para um tipo de jogo eletrônico no qual o objetivo é acertar os pregos de diversos cepos de madeira em movimento. No mesmo jogo, trechos do áudio

7 Plataforma de distribuição digital de vídeos fundada em fevereiro de 2005. Disponível em www.youtube.com

8 Rede social lançada em fevereiro de 2004. Disponível em www.facebook.com

9 Recentemente, a página mudou de nome para "Memes BR". Disponíver em

https://www.facebook.com/Oficialmemesbr/

10 Sistema Operacional de funcionamento de Smartphones.

11 Disponível para download em https://play.google.com/store/apps/details?

$\mathrm{id}=$ com.MbicharaApps.CepoDeMadeira\&hl=pt_BR 
extraídos do vídeo original foram transformados em comentários que Gugu faz, dependendo da performance do jogador. E, a cada momento em que se perde uma partida, é acionado um áudio com a voz do apresentador Faustão, gritando "Errou!"12. Além do grande alcance do vídeo, este se deslocou para outra mídia, uma espécie de convergência de mídia, como veremos adiante, a partir da brincadeira do garoto.

Esse é apenas um exemplo de mídia que "viralizou" por seu conteúdo cômico e se tornou meme ${ }^{13}$. Assim como nesse caso, incontáveis outras mídias são compartilhadas diariamente. Vídeos caseiros, trechos de telejornais, filmes, telenovelas, propagandas, fotografias, enfim, qualquer mídia passível de compartilhamento, em qualquer plataforma ou rede social pode, a qualquer momento, se tornar um meme. É impossível prever quando isso vai acontecer, pois quem tornará isso possível não será uma instituição ou empresa de comunicação, e sim os usuários dessas plataformas, conectados entre si e inseridos no que chamamos de cultura remix (NAVAS, 2012, MANOVICH, 2007, LESSIG, 2008).

A difusão e as diversas apropriações de mídias como essa são alimentados pelo que Lévy (2007) chama de inteligência coletiva. Este autor defende que as tecnologias de informação e comunicação (que, neste trabalho, chamaremos de TIC) facilitaram o trânsito de informação não apenas entre pessoas e conglomerados de mídia, mas entre as pessoas. "Ninguém sabe tudo, porém todos sabem alguma coisa" (LÉVY, 2007, p. 212). Isso significa que um usuário, ao necessitar determinada informação, pode buscá-la na rede junto a outros usuários. E dentre todos os tipos de informações partilhadas, estão mídias consumidas para entretenimento e humor - que, muitas vezes, são postadas por usuários comuns.

\subsection{A Cultura Remix}

Um conceito central para esse estudo é o de remix - considerado por Navas (2012) como uma das bases da cultura contemporânea. A prática do remix é baseada na apropriação e deslocamento de fragmentos entre diferentes contextos, propondo mudanças de significado e criação de novos discursos.

12 Tal fala se refere a um meme, que comentaremos no terceiro capítulo.

13 Exploraremos o conceito de meme no item 1.3 deste capítulo. 
Ainda apoiados em Navas (2012), chamaremos de sampling à atividade de extrair uma amostra de um todo, ou seja, um pedaço. Nos tempos atuais, o computador tornou o sampling uma atividade comum, a partir dos atos de copiar/recortar e colar. Considerando o remix como um processo, o sampling é a ferramenta que o torna possível, pois diz respeito à escolha do material a ser reapropriado.

Processos de criação assim sempre existiram, mas ganharam novas potencialidades após o surgimento da reprodução mecânica e, sobretudo, após as tecnologias digitais, que alteraram nossas formas de consumir e produzir cultura, pois a partir de um simples toque de teclas podemos extrair fragmentos de uma mídia a outra.

Os exemplos estão em toda parte: filmes produzidos a partir da adaptação de livros ou peças de teatro; remix musicais, que propõem novos arranjos sonoros para uma canção; obras arquitetônicas que se inspiram em formas já conhecidas; livros ilustrados com fotografias famosas; o retorno de tendências no campo da moda; os anime music vídeos (AMV's), que colocam cenas de desenhos animados japoneses ao som de canções pop; redublagens de cenas famosas de TV ou cinema; entre outros.

Pela abrangência dos exemplos, percebemos que a cultura contemporânea é fortemente caracterizada pela prática do sampling. Por isso, autores como Lev Manovich (2001), Lawrence Lessig (2008) e Rodrigo Navas (2012) afirmam que estamos vivendo uma cultura remix. Navas a define como "uma atividade global que consiste na troca criativa e eficiente de informações, possibilitada pelas tecnologias digitais e apoiada nas operações de recortar/copiar e colar" (NAVAS, 2012, p.159).

O remixer, ao manipular fragmentos, propõe relações alegóricas ${ }^{14} \mathrm{com}$ outras obras. Nesse ato de apropriação, ele pode optar por preservar ou não as características que tornem tais fragmentos reconhecíveis - o que Navas (2012) chama de "aura espetacular". Ou seja, para que uma obra seja reconhecida como remix, a "aura" da obra original (algum aspecto que a torne identificável) deve ser mantida. O termo "aura", aqui, difere-se daquele proposto por Walter Benjamin (1985) em "A Obra de Arte na Era da Reprodutibilidade Técnica", pois

14 Esclareceremos o conceito de alegoria no subcapítulo 1.6. 
este autor coloca que a obra já perderia a sua aura a partir de sua reprodução em cópias.

Navas atualiza o conceito de Benjamin, afirmando que a "aura espetacular" do remix está na possibilidade do reconhecimento de sua historicidade, ou seja, de saber a origem dos fragmentos ali atualizados. A reprodutibilidade técnica, problematizada por Benjamin, é vista por Navas como a força motriz das práticas de remix.

Manovich (2005) nos ajuda a compreender outro aspecto central para a emergência da cultura remix: o acúmulo de material. Se por um lado, se tornou mais fácil ter acesso à tecnologia; por outro, a nuvem de informação na qual estamos imersos se tornou mais densa, pelo constante acúmulo de dados. Artistas, remixers e usuários se utilizam desses materiais disponíveis na rede para produzir e comunicar.

Bourriaud (2009) caracteriza esse momento cultural e artístico como "pós-produção". Esclarece que no contexto de uma sociedade de consumo em expansão, com crescentes criações de novas necessidades em meio a um acúmulo de possibilidades já existentes, o artista acaba absorvendo a função de "comerciante", transferindo produtos entre diferentes espaços. Argumenta que o excesso de materiais disponíveis se tornou tão evidente que os artistas passaram a produzir a partir da apropriação desses objetos. Não haveria mais novidades vanguardistas no mundo da Arte que não fossem releituras das anteriores.

Pós-produção é como se chama a etapa da produção em cinema e televisão responsável por ajustes na imagem e no som, inclusão de efeitos visuais e áudios em oft e montagem. Bourriaud se apropria dessa ideia para designar a Arte Contemporânea, que se inscreve, segundo ele, em uma rede de significados já conhecidos, em vez de reivindicar uma aura de originalidade.

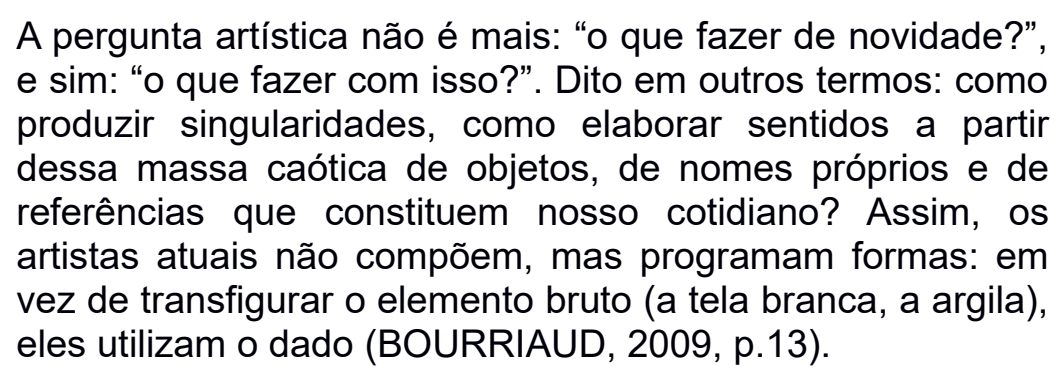

Bourriaud também esclarece que foi nos anos 1910, por meio do conceito do ready-made, que a apropriação se tornou um conceito "oficial" no mundo artístico. Tal conceito é atribuído ao artista visual Marcel Duchamp, que 
ganhou notoriedade a partir de obras como "Roda de Bicicleta" (1913), "Portagarrafas" (1914) e "A Fonte" (1917), que consistiam em objetos expostos com pouca ou nenhuma intervenção. No caso de "A Fonte", por exemplo, a obra se tratava apenas de um urinol comum, e na época, foi rejeitada pelo júri sob afirmação de que não havia nenhum labor artístico. Dessa forma, Duchamp problematizou, entre outras coisas, o conceito de produção. De acordo com o ready-made, atribuir uma nova ideia a um objeto também é um modo de produzir.

\begin{abstract}
Duchamp propõe isso como uma estratégia conceitual de recontextualização de um mictório comum como uma obra de arte: levando um mictório do mundo real e inserindo-o no mundo da arte para oferecer comentários sobre a prática da arte. Nesse sentido, ele está, literalmente, praticando um ato de corte, como entendido no remix, de tirar um sampling, um pedaço do mundo real, porque seu comentário precisa de um material de referência, a fim de produzir efeitos como uma contradição da singularidade da obra de arte (NAVAS, 2012, p. 77, tradução nossa).
\end{abstract}

A Pop Art, nos anos 1950 e 1960, também utilizou releituras e colagens para problematizar a massificação da cultura popular. Grande foi a contribuição dada por Andy Wahrol nesse tipo de arte, que ressignificou imagens da publicidade da época, como em duas de suas obras mais famosas, "Latas de Sopa Campbell" e "Caixas de Brillo".

Como Duchamp, Warhol abandona a estética, deixa seu ofício de desenhista, renuncia ao estilo, à habilidade manual, e se dedica à Arte - esfera que se dissocia das questões de gosto, de belo e de único. Os objetos que mostrará serão banais, kitsch, de mau gosto. Serão objetos de consumo usual: garrafas de Coca-Cola, fotos publicadas em jornais e rearranjadas. Em suma, duplicatas, remade. Exatamente como Duchamp, trata-se de mostrar o que já existe, mas ao readymade 'acrescentado' de Duchamp, que permanece único e quase impossível de ser encontrado, Warhol opõe a repetição em série, a saturação das imagens e o paradoxo de uma despersonificação hiperpersonalizada. "Seria fantástico se mais gente empregasse a serigrafia, ninguém jamais saberia se meu quadro é de fato meu ou se é de outro." Ou seja, todos os quadros poderiam ser perfeitamente seus (CAUQUELIN, 2005, p. 110).

Duchamp e Wahrol inspiraram muitos artistas nas últimas décadas. Mas a tendência de se apropriar de objetos e de discursos não se manifesta somente na esfera da Arte. Lessig (2008) acrescenta que o acesso à informação, atualmente, não tem o texto linguístico como principal referência. 
Acessamos conteúdo por meios múltiplos, sonoros e visuais, como vídeos, TV, internet, cinema e música. Se essa é nossa forma de ler o mundo, o autor sugere que também é a forma de "escrever" característica de nosso tempo: apropriar, citar e recombinar para comunicar.

Lessig aponta o lançamento da câmera Kodak nos anos 20 como um marco dessa transição. Os usuários, de posse de um artefato tecnológico, passaram a ter a possibilidade de serem "fotógrafos" sem treinamento específico (o que hoje é comum, na época era novidade). A tecnologia se tornou suporte de expressão pessoal. Tiezmann e Rossini (2013) acrescentam que houve uma tradição de gravação de vídeos domésticos, a partir de tal lançamento, em eventos familiares como aniversários e casamentos sobretudo a partir dos anos 1970, como esclarece Navas:

Uma vez que a ideia de capturar o mundo real (como uma forma de cópia) entrou no mundo material através reprodução mecânica, uma grande mudança na cultura começou a ocorrer, no século XIX, com a fotografia: a primeira tecnologia totalmente aplicada na captura como uma forma de sampling (NAVAS, 2012, p. 13, tradução nossa).

Para Navas, o termo remix começou a ser usado no campo da música nos anos 70, em Nova Iorque, Chicago e na costa leste dos Estados Unidos. Os DJs remixavam as músicas para se adequarem às respostas do público, realizando experimentos a partir de trechos de músicas já gravadas, tornando a prática do sampling conhecida.

Feitas estas considerações, esclarecemos que nossa pesquisa se orienta no sentido de investigar como se dá a relação entre riso e tecnologia, especificamente em videos online que usam como ferramenta os softwares Auto-Tune e Melodyne. Tais aplicativos permitem uma mudança semântica a partir do ritmo e do pitch, produzindo, assim, o riso. Escolhemos analisar o remix feito a partir de softwares, por entendermos a tecnologia digital como potencializadora destas práticas, e por identificar o uso cômico dessas ferramentas como uma subversão, já que não foram projetadas para tal ${ }^{15}$.

\subsection{Meio e técnica}

Para entender como o cômico se manifesta nos remix analisados, precisamos primeiramente situá-los em um ambiente mediado pela tecnologia. 
Por isso, consideramos importante entender a ideia de meio de comunicação e de internet.

A internet tecnicamente consiste em uma rede de computadores conectados mundialmente. Contudo, a definição de um meio de comunicação deve levar em conta não somente seu aspecto técnico, mas o social, ou seja, a ação humana que esse suporte proporciona. Compreendemos o seu sentido enquanto manipulado pelas pessoas e não apenas no plano técnico. As tecnologias de informação e comunicação não articulam trocas culturais por conta própria. Portanto, partimos do pressuposto que os meios de comunicação não são suportes passivos, mas tecnologias que impactam nossa vida e os conteúdos de mídia.

Para Martino (2000), a técnica é produto de uma atividade simbólica, na medida em que evolui pelo princípio da exteriorização de faculdades e procedimentos do corpo humano. Por exemplo, o martelo seria uma exteriorização de nossa força física; as rodas exteriorizariam nossa capacidade de deslocamento. Partindo de uma situação-problema (o deslocamento, por exemplo), a atividade técnica consiste em uma forma de raciocínio que identifica, isola e substitui um elemento de um circuito funcional por outro, de outro circuito funcional, que possa desenvolver uma atividade similar à que deve ser substituída. Ou seja, o raciocínio parte de uma comparação para uma substituição funcional. Esse raciocínio é de natureza simbólica e não absoluta (não há aparentemente nada em comum entre a mão e o martelo, mas simbolicamente podemos equacioná-los em função de um objetivo particular).

A técnica, portanto, não é apenas um conjunto de ferramentas, mas "uma atividade que se insere num processo evolutivo e histórico, necessariamente coletivo e intimamente ligado à faculdade de simbolização" (MARTINO, 2000, pg 110).

Além de estudar o meio pelo aspecto das técnicas, precisamos considerá-lo como transformador social. Os meios tecnológicos atuais são responsáveis pela virtualização do espaço social, pois boa parte da sociabilidade hoje acontece em rede. A noção de comunidade parte do pressuposto da convivência, e não necessariamente de tecnologias de comunicação. Nas comunidades primitivas, os indivíduos participavam por vínculo de sangue e tradição. $\mathrm{Na}$ atualidade, nos deparamos com uma sociabilidade mediada pela tecnologia. Nesse modelo de sociedade, os 
indivíduos ingressam em grupos sociais por engajamento e vontade próprios. As comunidades não deixam de existir, apenas mudam de configuração, e o que provoca essa mudança são os meios técnicos implementados (MARTINO, 2000).

Os meios de comunicação, então, representam nessa sociedade atual um espaço público de convivência, virtual, que alimenta as diversas comunidades, nas quais o cotidiano é compartilhado através de representações e geração de valores. Da mesma forma, do ponto de vista do indivíduo, os meios de comunicação são uma forma de se representar e integrar à comunidade, tomar conhecimento de fatos e acontecimentos com os quais se sente ligado. O estudo da formação de comunidades virtuais não é foco da presente pesquisa, mas vislumbrar tal mudança de paradigma nos ajuda a compreender o impacto proporcionado pelas TIC na estrutura da sociedade.

\subsection{Hiper-trash}

Até aqui, abordamos os meios pela ideia de mediação, ou seja, processos pelos quais usuários podem ter acesso à informação. Agora, trataremos de uma dialética, proposta por Jay David Bolter e Richard Gruisin (2000), entre dois conceitos, opostos, porém coexistentes e mutuamente dependentes: os de imediação e hipermediação - ligados às ideias de opacidade e transparência.

Esses autores defendem que os meios digitais nos passam uma sensação de ausência de mediação, o que gera um efeito de transparência, como se o usuário não mais confrontasse o meio, mas estabelecesse relação direta com a mensagem. Desse modo, a imediação "é a noção de que uma mídia pode apagar-se e deixar o espectador na presença dos objetos representados para que então possa conhecê-los diretamente" (BOLTER e GRUSIN, 2000, p. 70). Exemplos desse processo seriam os gráficos tridimensionais, a realidade virtual e os jogos de simulação em primeira pessoa, que na medida em que se desenvolvem e aperfeiçoam, proporcionam ao usuário a sensação de imersão em determinado universo ficcional, sem "lembrar" da mediação tecnológica. No campo do cinema, as tecnologias 3D e 4D possuem um objetivo similar. Porém, o conceito de imediação não está apenas ligado às tecnologias digitais e nem é uma novidade. Por exemplo, quando alguém lê um livro e se entretém de tal forma que "esquece" do mundo 
ao redor, podemos entender que o processo de imediação está ocorrendo. E é importante refletir que, por partir da relação do ser humano com diversos meios, a imediação depende da mediação para acontecer.

Por outro lado, os mesmos autores abordam outro conceito, oposto ao de imediação, que é o de hipermediação - a sensação concreta e evidente da mediação. O meio passa a se tornar mais importante que a mensagem, de modo que se torna visível, deixando de ser uma janela para o mundo e passando a ser uma janela em si (BOLTER e GRUSIN, 2000). Os autores consideram que tal processo se tornou mais presente após o advento das TIC. Por exemplo, podemos ter a sensação de imediação ao ver um vídeo no YouTube, porém, inevitavelmente, a hipermediação se afirmará quando precisarmos dar o próximo clique e nos depararmos com a plataforma.

Nesta perspectiva, há uma constante alternância entre imediação e hipermediação, sensação de transparência e de opacidade, e as tecnologias mudam de modo a potencializar a sensação de imediação, mas, para isso, se afirmando como mídias - esse processo de reposição e reformulação de mídias expressa o conceito de remediação (BOLTER e GRUSIN, 2000).

Hipermídias, segundo os autores, são caracterizadas pela convergência de conteúdos de várias origens em um mesmo meio. Podemos ter um conteúdo específico, como, por exemplo, uma página de um blog. O texto contido nessa página pode redirecionar o internauta para uma série de outros endereços da internet, apontando outras possibilidades de conteúdo.

A hipermediação se torna evidente em plataformas digitais como YouTube e Facebook, nas quais podemos navegar por uma série de conteúdos, que Manovich (1998) define como database. Isso nos leva a outra dicotomia, paralela à de imediação e hipermediação: a de narrativa e database.

Segundo Manovich, enquanto, por um lado, as narrativas pressupõem um desenvolvimento, com início, meio e fim, seguindo a ideia de causa e efeito, a lógica da database pressupõe o mundo como uma lista de itens cujo conteúdo temos à disposição para consumir a qualquer momento.

A lógica da database, em menores proporções, sempre esteve presente na cultura. Antes do advento das TIC, ela existia no plano das ideias enquanto conceito imaterial, em conteúdos em potencial, ao passo que as narrativas eram a expressão material desse conteúdo. As TIC materializaram a database, privilegiando-a em função da narrativa. 
Em última instância, podemos afirmar que a internet se constitui como um banco de dados, listados através de links. $O$ autor esclarece que a narrativa pode ocupar a database, e é isso o que acontece em sites como o YouTube. A infinidade de mídias disponíveis são disponibilizadas em uma lista, contudo, um vídeo pode conter uma narrativa. Consideramos, a partir dos conceitos expostos, que a alternância dicotômica entre narrativa e database ganha ecos com aquela entre imediação e hipermediação.

Esse cenário que esboçamos até aqui nos ajuda a compreender as condições de elaboração dos materiais: para elaborar um remix, os realizadores acessam a database, de natureza hipermidiática e dotada de uma quantidade gigantesca de material, e extraem o que lhes interessa para construir suas narrativas - muitas vezes, tomando como referência formal um template, ou seja, uma forma mais ou menos pré-definida, como no caso dos vídeos que analisaremos.

A ideia de database é importante para nossa pesquisa, por caracterizar o ambiente no qual os remixers interagem e selecionam seus materiais para reelaboração. Também podemos pensar na database, ou "datasmog" (SHENK, 1997 apud FELINTO 2007) enquanto "lixo digital".

Antes da internet, as emissoras de TV e rádio veiculavam seus produtos midiáticos e apenas quem dispusesse de um gravador de som ou videocassete com função de gravar poderia obter um arquivo de determinado produto. Hoje, a rede é alimentada constantemente com material que usuários gravaram ou produziram (alguns, por meios analógicos, convertidos para digitais), e outros fornecidos pelas grandes corporações midiáticas (FONTANELLA, 2009)

Todo esse "lixo digital" - entendido aqui não como uma categoria inferior de informação, mas como "detrito" midiático ou simplesmente arquivo hipermidiático - não se encerra em cestas ou debaixo do tapete, mas faz parte da vida, como uma poeira presente em todo o espaço, database da cultura. Em termos estéticos, trata-se de conteúdos que dificilmente seriam veiculados pelas mídias tradicionais, tais como vídeos caseiros, arquivos sem relevância comercial explícita e videos remix, como os que analisaremos.

Fontanella também aponta uma intencionalidade, por parte de quem produz e difunde o digital trash, em uma estética "tosca". Frequentemente, esse tipo de conteúdo viraliza ${ }^{16}$ nas redes por seu apelo humorístico. A prolifera, enquanto o segundo necessariamente se transforma. 
celebração desse "lixo" teria, então, relação direta com o excesso audiovisual que constantemente se acumula na rede, "desafiando hierarquias de qualidade técnica e estética culturalmente estabelecidas" (FONTANELLA, 2009, p. 3).

Lemos celebra o digital trash como uma fuga à padronização do gosto, que teria sido imposta pelos tradicionais conglomerados de mídia: "se pensarmos bem, a cultura digital é aquela que me permite o luxo da escolha, o luxo da garimpagem, o luxo do excesso e da profusão de coisas para além do gosto médio. Isso é que faz a riqueza da internet”. (LEMOS, 2009, p. 10)

Felinto (2007) afirma que a estética de mal acabamento de muitos vídeos pode ser vista de dois modos: por um lado, como índice de pobreza de recursos (quando há, lembrando que há muitas produções amadoras de alta qualidade técnica e de acabamento) e por outro, como abertura à intervenção e participação criativa do público.

A capacidade de o espectador ter voz "ativa" nesse contexto, ou seja, de produzir e divulgar seu próprio conteúdo, não significa, a priori, uma atitude transgressora em relação aos grandes meios de comunicação. Pelo contrário. Muitas vezes os novos meios apenas reiteram o velho "consumo confortável". O suposto espaço de voz que o espectador conquistou, na verdade habilita as indústrias a pensarem novas formas de lucrar a partir disso, desenvolvendo novos produtos e novas formas de relação com o consumidor.

\subsection{Semiosfera, Ludosfera, Memesfera}

Em meio a todas as características apontadas até aqui, consideramos importante introduzir mais um conceito, o de Semiosfera, pensado por Lotman (apud MACHADO, 2010), como um espaço no qual operam diversas relações entre cultura e linguagem, deixando claro que estes não acontecem de forma isolada. Lotman trabalha com a ideia de meio como "um dispositivo pensante, dotado de inteligência e memória" (HORTO, 2015, pg. 23).

Lotman vai além da ideia de comunicação concebida como um fluxo bidirecional de transporte e transmissão de informações entre emissor e receptor, mas como um circuito dialógico que proporciona conexões entre diversos códigos culturais (HORTO, 2015). O autor considera que os processos comunicacionais ocorrem em diálogo com a cultura, que é tida como um organismo vivo, dinamizador, um dispositivo dotado de inteligência. A 
semiosfera, então, abrange a cultura como espaço que não apenas opera, mas dinamiza e transforma práticas comunicacionais.

A ideia de semiosfera parte de uma analogia a um conceito da Biologia, o de biosfera: um "habitat" no qual os signos coexistem e se inter-relacionam; a totalidade da cultura imersa em um espaço dinamizador e interativo entre fluxos de informação. Tal designação dota esse ambiente de concretude e materialidade. Assim como a vida na biosfera precisa da biodiversidade para que a vida se perpetue, a mesma relação de dependência tem a semiosfera com a semiodiversidade, que garante a vida não biológica, mas de relação (LARIZZATTI, 2013). Tal noção é importante para essa pesquisa por considerar os textos não de forma isolada, mas como espaços dentro dos quais ocorrem múltiplos fluxos e diálogos com outros.

Lotman esclarece que não há apenas "uma" semiosfera. Dentro de uma, podem haver várias outras possíveis - assim como uma biosfera é composta de diversos ecossistemas, que por sua vez possuem outras subdivisões. $\mathrm{Na}$ cultura, existem diversos núcleos de comunicação, que se conectam, estabelecendo canais de comunicação entre si e se somam, até formar um "todo". Consideramos, desse modo, os remix analisados aqui como um núcleo de semiosfera.

Feito esse rápido apanhado conceitual, e partindo da ideia de meio como extensão da consciência, de modo hipermidiático, podemos vislumbrar uma semiosfera formada por um coletivo de consciências, ou, permitimo-nos pensar, uma consciência coletiva, um dispositivo pensante, ideia que dialoga com o conceito de "inteligência coletiva", formulada por Pierre Levy e retomada por Henry Jenkins (2009), que abordaremos adiante.

Larizzatti (2013) parte do conceito de semiosfera, de Lotman, levando em consideração o aspecto dos jogos de linguagem na hipermídia, para propor outro conceito: o de Ludusfera. Este autor parte da afirmativa de que o jogo é uma possibilidade de fonte de conhecimento e aprendizado para pensar nas mídias digitais, para apontá-lo como modelizador de experiências inovadoras na cultura: "O ser humano, chamado de Homo sapiens, merece também ser chamado de Homo ludens, pois considera o jogo toda e qualquer atividade humana, sendo presente em tudo o que acontece no mundo" (LARIZZATTI, 2013, pg. 139). 


\subsection{Brincando de remix}

A ideia de ludusfera nos parece interessante, pois percebemos um aspecto lúdico na elaboração dos remix analisados. Bergson (1983), ao caracterizar a comédia, a compara com a imagem de um brinquedo:

Ora, a comédia é um brinquedo, brinquedo que imita a vida. $\mathrm{E}$ se, nos brinquedos infantis, quando a criança lida com bonecos e polichinelos, tudo se faz por cordões, não serão esses mesmos cordões, gastos pelo uso, o que iremos encontrar nos cordéis que articulam as situações da comédia? (BERGSON, 1983)

Ao desenvolver esse raciocínio, Bergson apresenta diversos tipos de brinquedo, comparando seu funcionamento com o de diferentes formas de comédia. Uma delas é a do fantoche ou marionete. Ele os compara com personagens de diversas comédias que são manipulados por outros. Nesses casos, a personagem manipulada crê agir e falar livremente, quando, na verdade, está sob o controle de outro, como um simples brinquedo em suas mãos. O espectador ri porque não sente compaixão do ser manipulado, ficando do lado do "trapaceiro", na posição de cúmplice.

Retomando a ideia de "ludusfera", é possível entender que o remix, quando tem finalidade cômica, funciona como um tipo de brinquedo. $\mathrm{O}$ conteúdo remixado é manipulado como fantoche. Os remixers são os manipuladores desses bonecos, apesar de não serem exatamente seus "donos". Seguindo a lógica dessa metáfora, podemos dizer que no mundo da internet, os brinquedos não possuem "donos", pois estão inseridos na lógica da inteligência coletiva e da cultura remix. Na imagem a seguir, podemos ver como a distorção da imagem é utilizada com finalidade cômica em um video remix.

Figura 1: Trecho do remix "Top", do canal Viradrop.

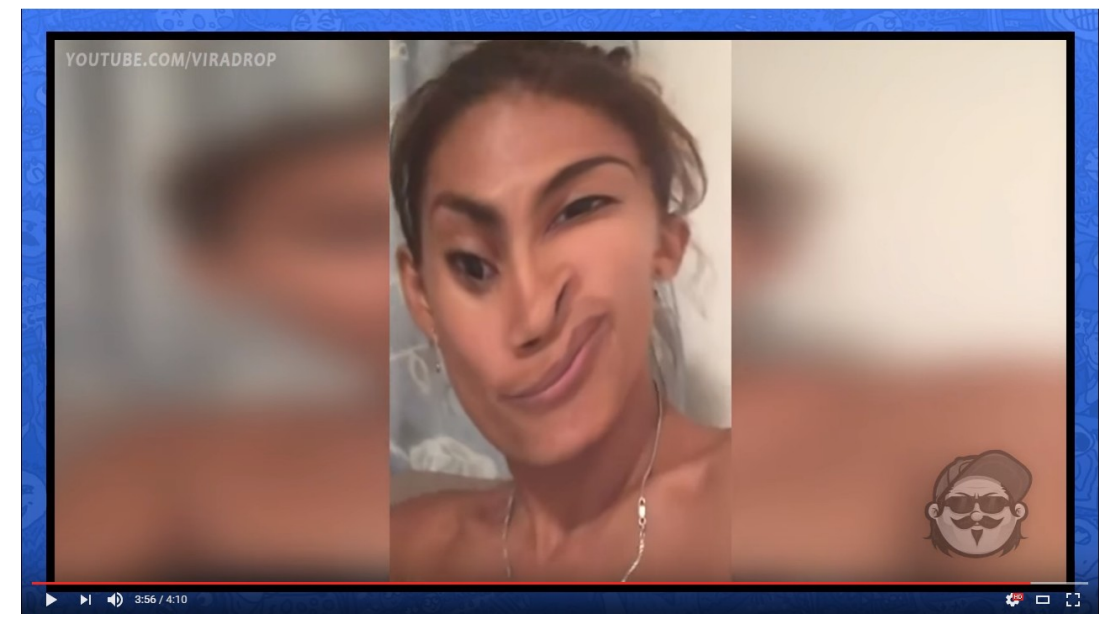

Fonte: https://www.youtube.com/channel/UCCjJ6nzg3-74FbISqmE_EcA 
Larizzatti afirma que a interatividade hipermidiática opera sob a semiosfera do jogo. Ou seja, as práticas de sampling, que ocorrem muitas vezes espontaneamente, podem ser uma forma de diversão. $O$ autor caracteriza o lúdico como uma atividade presente na cultura desde as comunidades primitivas (que o usavam em festejos e na criação de mitologias e cultos, que determinavam convenções e instituições sociais) até a sociedade atual, que se sustenta por trocas monetárias, leis, movimentos artísticos e científicos. Descreve também o jogo como uma forma de conhecer o mundo e de construir conhecimento, funcionando como hipermídia, na medida em que parte de uma base técnica (uma regra) para a atividade de revigorar ou transmutar conceitos.

Fontanella (2009), tomando como base também a ideia de semiosfera, e a de ludusfera, propõe, para a compreensão do mundo contemporâneo, a retomada de outro conceito: o de memesfera (PICKARD, 2008 apud FONTANELLA, 2009). Antes de adentrar na memesfera, precisamos esclarecer o conceito de meme.

A partir da publicação do livro "O Gene Egoísta", lançado por Richard Dawkings em 1976, a expressão $m e m e^{17}$ se tornou difundida pelo senso comum e está ligada à repetição e replicação de uma mesma informação, com diferentes apropriações. Neste livro, o autor usa o conceito de meme como expressão cultural do gene, unidade básica de informação ou memória que um ser humano transfere conscientemente para outro. O termo tem origem na palavra grega "Mimeme", que significa "algo que é imitado".

Dawkins também propõe um conceito, parecido ${ }^{18}$ com o de semiosfera, que é o de caldo cultural. O termo faz alusão ao caldo primitivo no qual as primeiras bactérias se desenvolveram, replicaram e sofreram mutações, na base do processo evolutivo na terra, segundo Darwin. Partindo dessa analogia, Dawkins afirma que assim como os genes se reproduziam e, de alguma forma, buscavam a sobrevivência através de replicações e mutações; os memes, na nossa civilização, competem pela sobrevivência em nossa atenção e memória.

17 É importante, aqui, frisar que a ideia de meme de Dawkins não é a mesma que o senso comum difundiu nos tempos atuais. Diferenciaremos, portanto, a ideia de meme, proposta por Dawkins e por seus seguidores, de um recorte mais específico, em certo ponto parecida com a do senso comum, que são os remix cômicos veiculados em rede.

18 Para averiguar as diferenças e limitações do conceito de clado cultural em relação ao de semiosfera, consultar FONTANELLA (2009) 
Os memes são, segundo essa linha de pensamento, toda unidade de informação que obedece três características: a longevidade - seja curta ou longa, a informação precisa "sobreviver" durante algumas replicações - a fecundidade - pois durante as replicações, a informação pode ser propagada e sofrer mutações; e a fidelidade - que garante que, apesar das mutações, a unidade de informação seja reconhecível. Ou seja: os memes são remix.

A ideia de memesfera, portanto, torna particular a noção de semiosfera, levando em consideração o caráter lúdico do ser humano e seu comportamento em rede, mediado por tecnologias digitais. Tal conceito nos parece útil para pensar no humor na cultura remix fundamentado no modo de funcionamento dos memes de internet, que constantemente fazem alusão a referências e informações que já são do conhecimento de determinada comunidade, trabalhando na lógica da alegoria.

Segundo Navas (2010), a alegoria ocorre quando um há uma conexão entre dois textos, de modo que um é entendido através do outro, ainda que de forma caótica. O alegorista se apropria de imagens já existentes em vez de criá-las, e é na atividade da leitura que ela se concretiza, pois cabe ao leitor estabelecer a conexão entre esta e aquela.

Navas afirma que o remix é alegórico ao convocar no espectador/leitor/ouvinte o reconhecimento do contexto original de algum fragmento ali presente. Ou seja, o remix depende do reconhecimento dos textos pré-existentes, de modo que a alegoria seja reconhecível.

Afirma que no Modernismo, quando objetos eram ressignificados haviam códigos que ocultavam a origem, as histórias e políticas que haviam por trás do objeto, ao passo que o Pós-Modernismo remixa o modernismo expondo como a arte se encaixa em um fluxo de revisitações.

Tomando como base esses conceitos e reflexões, acreditamos que, na cultura remix, o riso opera pela abertura de janelas. Cada piada carrega em si outra, cada elemento cômico faz alusão a algo por trás.

\subsection{A plataforma Youtube}

Segundo Burguess e Green, o YouTube funciona como "um importante mecanismo de mediação para a esfera cultural pública" e "um instrumento de viabilização de encontros de diferenças culturais e o desenvolvimento de 'audição' política entre sistemas de crenças e identidades” (BURGUESS e 
GREEN, 2009, p. 107). Consideramos o site, portanto, não apenas como um processo tecnológico, mas social e coletivo.

O site hoje conta com mais de um bilhão de usuários, quase um terço dos usuários de internet no mundo inteiro, podendo ser acessado em 76 idiomas diferentes. ${ }^{19}$ Surgiu em junho de 2005 e foi comprado pela Google por 1,65 bilhão em outubro de 2006. Recentemente, a empresa Google passou a se chamar Alphabet Inc, abrangendo, como sob um guarda-chuva, diversas outras empresas. A razão do nome está na variedade de empresas, desde "A" (Android) até projeto (Z)ero ${ }^{20}$. Uma dessas empresas é o YouTube. Portanto, hoje, todos os usuários no YouTube são usuários cadastrados na Alphabet Inc.

Figura 2: Página inicial do YouTube a partir de 2014

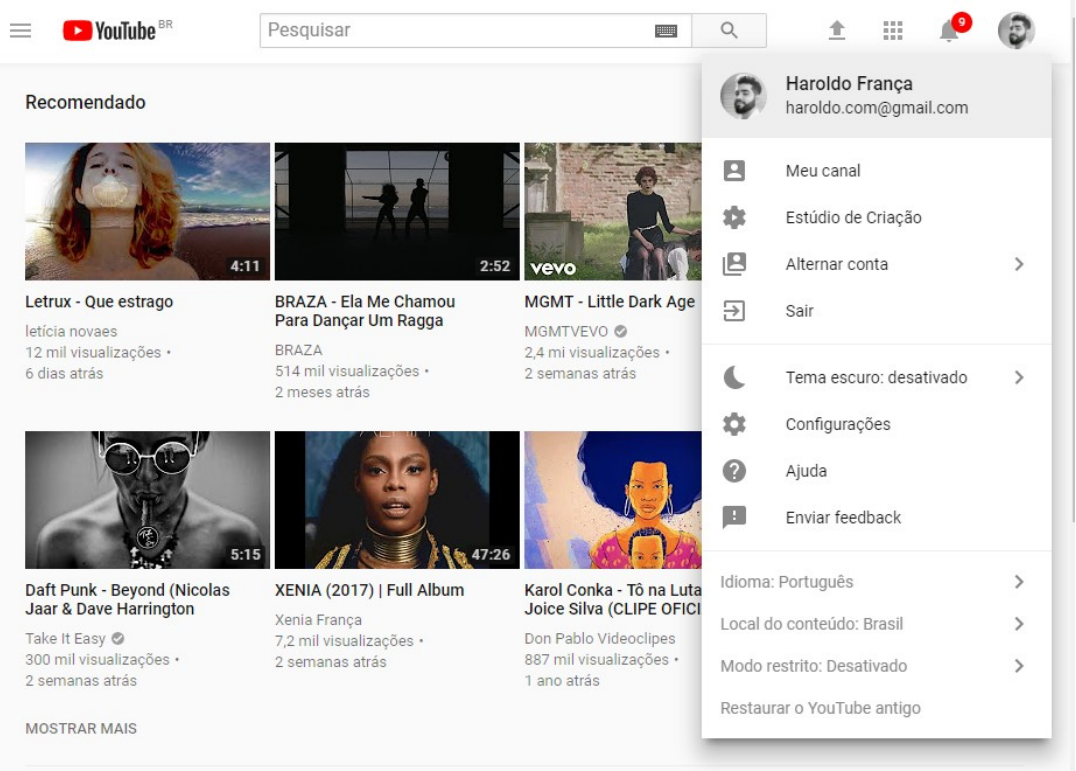

Fonte: http://www.youtube.com

Também é importante destacar que, além de um simples site, o YouTube funciona como plataforma. Característico da Web 2.0, tal formato possibilita que diversos softwares possam funcionar online, integrados de maneira funcional em um mesmo "ambiente".

O site oferece espaço para criações feitas por uma pessoa só, ao passo que na TV, tudo o que é transmitido passa por várias equipes e pelo crivo dos patrocinadores; embora esse formato possibilite também a divulgação do trabalho original de artistas individuais.

19 Disponível em: https://www.youtube.com/yt/press/pt-BR/statistics.html 20 A lista com todas as empresas está disponível em http://g1.globo.com/tecnologia/noticia/2015/08/alphabet-veja-listade-todas-letras-da-novagoogle-de-ndroid-zero.html 
É possível, a partir desse panorama, deduzir que espectadores de TV são "passivos" assim como usuários de YouTube são "ativos", cheios de opinião, questionadores e abertos ao diálogo. Contudo, essa é uma visão estereotipada e preconceituosa, visto que os dois sistemas estão articulados na mesma cultura; e também porque a maioria absoluta dos usuários do site nunca fez upload de uma mídia sequer, e navega no site apenas para assistir "passivamente" os vídeos que the são sugeridos ou listados (DIJCK apud VALCK, TEURLINGS, 2009).

O site foi lançado como um repositório de vídeos, mas os usuários acabaram transformando-o em uma plataforma destinada à expressão pessoal, como explicitou um de seus slogans: "Broadcast yourself" (algo como "transmita-se"), o que enfatiza a união entre informação privada e exibição pública. Um processo que durou alguns anos e contou com atualizações desenvolvidas pela plataforma.

A primeira versão da página inicial do site (também conhecida como home, o ponto de partida de onde se começa a navegar) já apresentava, na barra superior direita, o usuário em destaque. Também haviam listas de sugestões de vídeos com tendências globais, como "mais vistos" ou "vídeos do momento".

Em 2012 houve uma mudança no design da página inicial. O destaque para o usuário ficou mais evidente, não apenas por sua disposição visual, mas pelo modo de funcionamento que a interface passou a ter. As listas continuaram, mas com sugestões mais personalizadas. O usuário, aqui, é um sujeito individualizado, que a partir dessa página dispõe de diversas vias por onde navegar e estabelecer conexões com outros usuários, vídeos, canais, empresas, etc. Os elementos à disposição passaram a ser não apenas globais, mas locais (MONTAÑO, 2017), como suas preferências, dados pessoais, atividades e sugestões específicas. A plataforma situa-o em uma vizinhança, um universo no qual diversos usuários e mídias coexistem.

A partir de 2014, a plataforma sofreu outras alterações. Além de manter o poder comutativo entre os usuários e potencializar a inteligência coletiva, o site passou a considerar o usuário não mais como alguém capaz de "enviar", mas de "criar" vídeos. Ainda no canto superior direito da plataforma, o espaço destinado ao usuário se mantém, mas com um tipo diferenciado de 
identificação. As listas, agora, estão organizadas em bibliotecas e além disso, o "estúdio de criação" foi inserido como espaço diferenciado na interface.

O link do estúdio de criação não leva apenas a uma biblioteca de vídeos, mas a uma verdadeira plataforma de criação e transmissão online, dotada de várias funcionalidades. São disponibilizados gratuitamente músicas e efeitos sonoros para download. Um "serviço" de tradução de idiomas é oferecido, no qual o usuário envia o vídeo para que outros o traduzam.

O status do usuário foi elevado ao de produtor profissional ou, no mínimo, um aprendiz. Recebe orientações para gerar renda a partir de seus vídeos; para aplicar corretamente a logomarca do YouTube, para administrar o seu "negócio", expandir seu público, etc. A aba "Analytics" permite acompanhar em gráficos detalhados as visualizações dos vídeos publicados. $\mathrm{Na}$ aba "comunidade", é possível conferir todas as últimas interações com outros usuários.

A participação do usuário no YouTube se dá por meio da formação de um banco de dados. O primeiro passo é o login, que pressupõe um cadastro, e a partir de então esse usuário pode navegar tanto pelo seu próprio perfil (com informações e preferências pessoais), quanto por outros, deixando rastros: as inscrições nos canais, o conteúdo que compartilha, os comentários, avaliações, envios, etc. Ou seja, o usuário não é apenas um ser que manipula o YouTube, mas uma parte integrante de sua arquitetura de participação.

\subsection{Bottom-up}

A inserção das TIC no cotidiano reconfigurou os padrões de acesso à cultura. Os usuários deixaram de ser meros "receptores" de conteúdo e passaram a elaborar uma quantidade de conteúdo gigantesca a ser compartilhada por qualquer pessoa no globo. Lessig (2008) caracteriza essa nova configuração de acesso à cultura como a retomada do RW (read/write) modo de acesso à cultura experimentado somente em comunidades primitivas, antes que houvessem meios de comunicação monopolizadores da distribuição de conteúdos e da formação de uma cultura de massa.

A facilidade de acesso a softwares de design sonoro e visual, disponíveis para download (muitas vezes por meios ilegais) - aliada à existência de tutoriais e fóruns disponíveis para ensinar pessoas a operar esses softwares - torna possível que qualquer pessoa com acesso à internet e 
compatibilidade de hardware possa realizar montagens e remix audiovisuais. Uma das características que diferencia a fase pós-massiva da comunicação dos estágios anteriores é a posição ocupada pela figura do amador, que cresceu a ponto de se tornar inimaginável e indispensável (FLICHY, 2016).

Mesmo sem diplomas ou distintivos que os caracterizem como "profissionais" ou "experts", tais usuários, por iniciativa autodidata, conseguem se desenvolver no manuseio da técnica, de modo que muitas vezes conseguem realizar trabalhos de acabamento similar ao dos ditos profissionais. Desse modo, muitas vezes o que distingue um trabalho profissional de um amador não é o seu acabamento e sim a sua legitimidade (FLICHY, 2016).

Desse modo, um amador pode se tornar um especialista, tendo suas aptidões desenvolvidas no cotidiano de modo espontâneo. Essa ação é proporcionada pelo que Jenkins define como cultura participativa, caracterizada por uma realidade na qual fãs e outros consumidores participam ativamente da criação e circulação do novo conteúdo (JENKINS, 2006).

A cultura participativa é um dos pilares do que Jenkins denomina de cultura da convergência. Trata-se de uma tendência tecnocultural, na qual conteúdos de mídia dispersos são utilizados pelos usuários na busca por informações e conexões. Dispositivos de mídia como smartphone, tablet e TV estão à disposição e são meios de comunicação que se interconectam pela cultura dos usuários. A cultura da convergência acontece em três pilares: convergência dos meios, cultura participativa e inteligência coletiva.

A convergência dos meios diz respeito a conteúdos elaborados para mais de uma plataforma ou dispositivo eletrônico. Jenkins nos alerta que essa convergência não implica em uma tendência à unificação tecnológica dos meios - como se todas as funções de comunicabilidade fossem concentradas em um aparelho. Múltiplos meios tecnológicos continuam existindo, mas seus conteúdos muitas vezes são direcionados aos mesmos empreendimentos midiáticos. O autor aponta essa tendência também como estratégia econômica, pois grandes conglomerados da indústria passaram a perceber que potencializam suas possibilidades de lucro pensando em produtos que possam se expandir em diversas mídias e linguagens. Cabe aqui lembrar que as mídias tradicionais permanecem ativas na cultura pós massiva, convergindo também com as mídias digitais. 
Como exemplo, podemos citar a webcelebridade Bambam, exparticipante do programa Big Brother Brasil ${ }^{21}$; veiculado pela Rede Globo, tendo também vídeos postados no YouTube, passando a ser alvo de diversos remix, como o caso do vídeo "Bambam Enlouquecendo / Bambam Bodybuilder", do canal Viradrop ${ }^{22}$, no qual a figura de Bambam é posta "cantando", pela alteração de tempo e pitch da voz.

Figura 3: Trecho do remix do vídeo "Bambam Enlouquecendo / Bambam Bodybuilder", do canal Viradrop

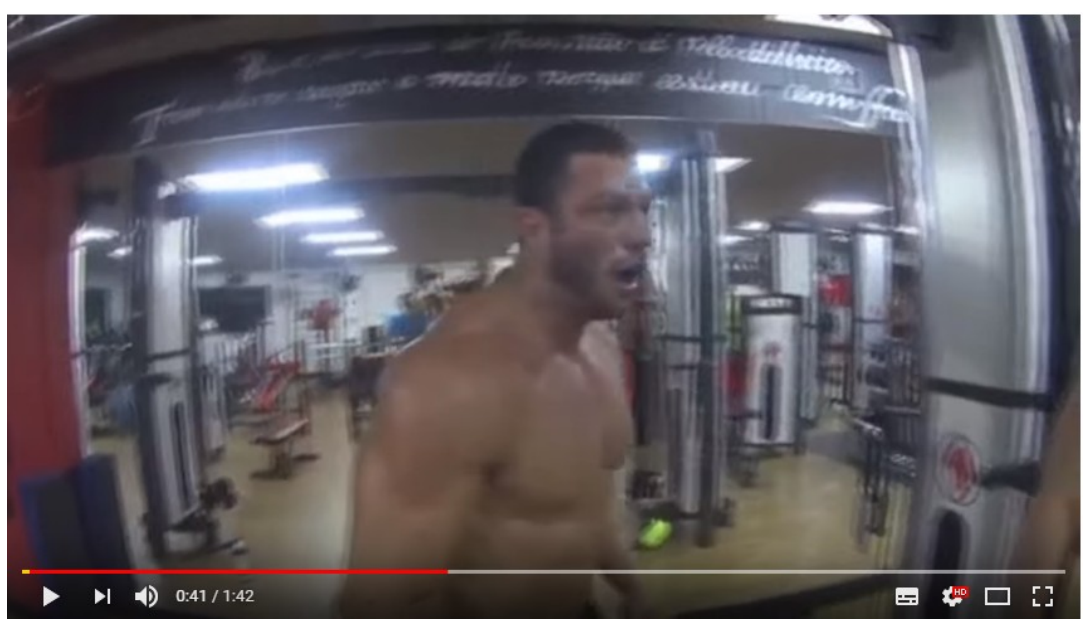

Fonte: https://www.youtube.com/channel/UCCjJ6nzg3-74FbISqmE_EcA

A cultura participativa é estimulada por protocolos tecnológicos e culturais. No exemplo citado, existe a apropriação de uma figura conhecida para elaborar - por meios tecnológicos - um discurso que ridiculariza um grupo social, representado ali por Bambam. Tal proposição se manifesta como participação na cultura, suscitando múltiplas interações.

Jenkins distingue interação e participação, esclarecendo que a interação acontece na esfera da tecnologia, e a participação, na cultural. O suporte técnico desse ambiente comunicacional possibilita a interação, facilitando a cultura participativa em termos de velocidade, praticidade e alcance, mas esta participação só ocorre porque também é culturalmente estimulada (as formas de engajamento do público se dão em protocolos culturais). Participação e interação, na realidade das mídias de massa, sempre existiram; contudo, existiam limitações maiores, e um maior controle entre emissores e receptores. Com a liberação do polo da emissão, que marca a comunicação pós-massiva

21 Versão brasileira do reality show Big Brother. Sua primeira edição iniciou em 29 de janeiro de 2002, com uma segunda temporada sendo exibida no mesmo ano (fonte: wikipédia) 22 Disponível em https://www.youtube.com/watch?v=leXDXGkpBQY 
(LEMOS, 2004), a cultura participativa se tornou uma realidade mais presente.

Essa motivação pode ou não partir dos produtores.

A inteligência coletiva (termo cunhado de Pierre Levy, como explicitado no início deste capítulo) é um paradigma no qual pela união de informações coletadas por diversas pessoas, obtêm-se um conhecimento de interesse de todos. Fãs podem se reunir em fóruns para debater sobre detalhes de séries as quais acompanham, de modo que em rede, o conhecimento sobre determinado assunto é acumulado e compartilhado. O conhecimento do mundo é muito extenso, e a quantidade de conteúdo disponível em rede também, de modo que dificilmente uma pessoa só detém todo o conhecimento sobre determinado assunto. A rede facilita a interação, portanto as pessoas se unem em prol da solução de problemas que envolvam conhecimento.

\subsection{Auto-Tune e Remix}

Inicialmente, cabe esclarecer que a alteração eletrônica da voz humana já fazia parte da paisagem da música pop quando o Auto-Tune foi lançado. Alguns artistas como Michael Jackson (na canção PYT, 1983), Kraftwerk e Giorgio Moroder (ambos nos anos 1970) já utilizavam softwares como o Vocoder, subvertendo a voz humana, aproximando seu timbre ao de instrumentos eletrônicos. A música techno também já incorporava em si a sonoridade dos sintetizadores, estabelecendo tramas de sons artificiais, de modo que a voz era manipulada "até camuflar totalmente seu caráter humano" (JARAMILLO, 2005, p. 132).

Lucentini (2016) afirma que as tecnologias eletrônicas e digitais do som motivaram diversos artistas a agregarem em seus experimentos 0 processamento sonoro ao vivo ou em estúdio, por meio de processadores de efeitos, pedais, plugins e softwares de programação:

"Desde a propagação de métodos baseados na eletricidade para a gravação da voz, a reprodução da voz, a transmissão da voz, a recepção da voz, a montagem da voz e a síntese da voz no início do século 20, uma "vocalidade" abstratamente entendida vem substituindo vozes humanas concretas. A voz do locutor tornou-se separada da pessoa do orador, assim como a voz do cantor tornou-se separada da pessoa do cantor. (...) acessando meios eletroacústicos de produção, o indivíduo contemporâneo aproveita a possibilidade de manipular a percepção dos outros. Ao modificar amplitudes, frequências e mudanças de fase, os transformadores eletrônicos da voz permitem ao usuário modelar novos quadros de comunicação e novas 

de pronúncia" (ZAKHARIANE, 2013, apud LUCENTINI, 2016, p. 96) .

Também podemos citar como exemplo Laurie Anderson, artista performer que produziu performances que evidenciavam a relação entre ser humano e tecnologia através de performances multimidiáticas, com diversas alterações vocais executadas ao vivo, colocando vozes masculinas e femininas em um mesmo corpo (STOROLLI, 2015, LUCENTINI, 2016).

Na música, assim como em outras áreas do conhecimento, existe uma hibridização entre práticas amadoras - as realizadas por pessoas sem formação musical, autodidatas - e profissionais, à medida que a informática tornou possível compartilhar conhecimentos musicais com a inteligência artificial e alcançar resultados equiparáveis aos profissionais. Esses "músicosinformatizados (Flichy, 2016) costumam converter o prazer de escutar no prazer de criar. A divulgação do resultado disso é plenamente possível nas redes sociais, sites de compartilhamento e mesmo no Spotify ${ }^{23}$.

O Auto-Tune surgiu em 1997, criado pela empresa Antares Audio Techologies, como um plug-in do software Pro Tools. Seu objetivo é a correção e afinação sonora na fase de pós-produção de gravação de música profissional, por meio da alteração do pitch do som. Ele torna possível corrigir a afinação da voz de um cantor ou mesmo de um instrumento que não tenha entrado no "tom" correto da música. Além de ajuste de pitch, o aplicativo traz outras possibilidades como equalização, reverberação, e delay.

O seu lançamento provocou mudanças significativas na indústria musical, tanto em termos técnicos como poéticos. Uma gravação, que antes poderia levar horas, passou a durar minutos. Artistas que já faziam parte do cenário musical, como no caso do Hip-Hop, puderam experimentar novas formas de música, com a inclusão de trechos melódicos. Outros artistas que já cantavam passaram a experimentar novos efeitos sonoros por meio do software.

Em 2009, Jay-Z lançou o single "Death of Auto-Tune". No clipe, o rapper aparece ateando fogo a pilhas de caixas de computadores. No mesmo ano, a banda indie Death Cab For Cutie fez um pequeno protesto contra o aplicativo no Grammy, conhecido evento de música.

23 Serviço de música comercial em streaming. 
Mesmo assim, o Auto-Tune se impôs como uma importante ferramenta de estratégia econômica. Não é apenas a questão de fazer uma pessoa desafinada cantar bem, mas também economizar tempo e dinheiro sem precisar gravar a mesma canção várias vezes, considerando que um estúdio cobra por tempo, assim como profissionais da engenharia do áudio.

Figura 4: Interface do Auto-Tune

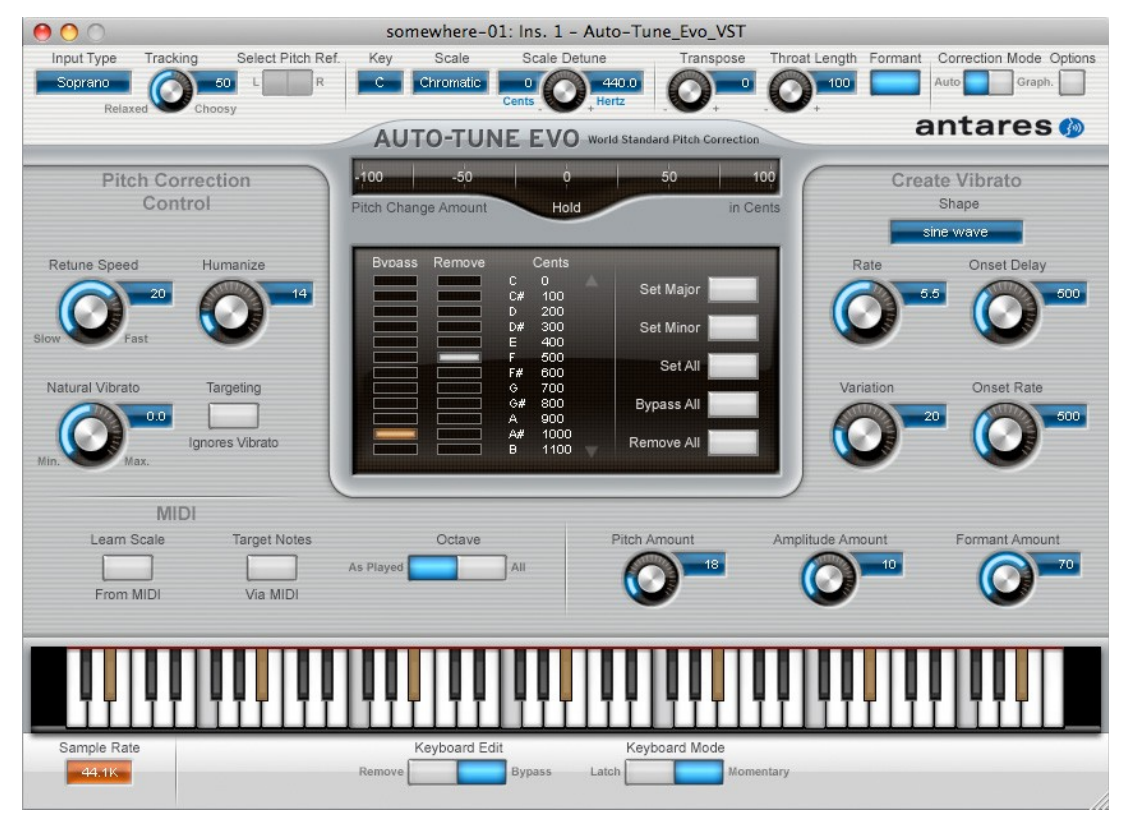

Fonte: Print screen do software Auto-Tune.

Antes do Auto-Tune, uma gravação inteira poderia ser descartada por um único erro. Agora, isso não é problema, pois é possível corrigir um ou outro trecho desafinado, sem que isso soe artificial. Dessa forma, essa tecnologia pode se mostrar útil mesmo para cantores profissionais.

O aplicativo também forneceu novas possibilidades estéticas à música. Uma das variáveis do aplicativo se chama "Tempo de ajuste". Para correções sutis, que não percam muito da naturalidade da voz, o tempo de ajuste deve ficar acima de 15. O que ocorre é que, seja por escolha estética ou inexperiência do produtor musical, são colocados valores abaixo disso e até zero, o que deixa a voz bastante robótica.

O produtor musical Mark Taylor, que trabalhou no álbum "Believe", da cantora Cher (1998), experimentou configurar o tempo de ajuste em zero. $O$ efeito, bastante exagerado, acabou agradando o público, de modo que a empresa Antares Audio Techologies conseguiu da artista permissão para divulgar que tal efeito era realizado com o software. O sucesso foi grande e no final dos anos 90 e início dos anos 2000, na música pop, o Auto-Tune prevaleceu na maioria dos estúdios. 
O produtor conhecido como T-Pain (Faheem Rasheed Najm) levou a sonoridade do tempo de ajuste em zero para o Hip Hop, em 2003. Ficou tão conhecido por essa sonoridade específica que a Apple criou um aplicativo chamado "I Am T-Pain", para usuários de iPhone, iPads e similares experimentarem o efeito na própria voz. Após essa popularização, o software de T-Paim passou a ser abertamente veiculado em programas humorísticos de televisão.

Figura 5: Interface do Melodyne

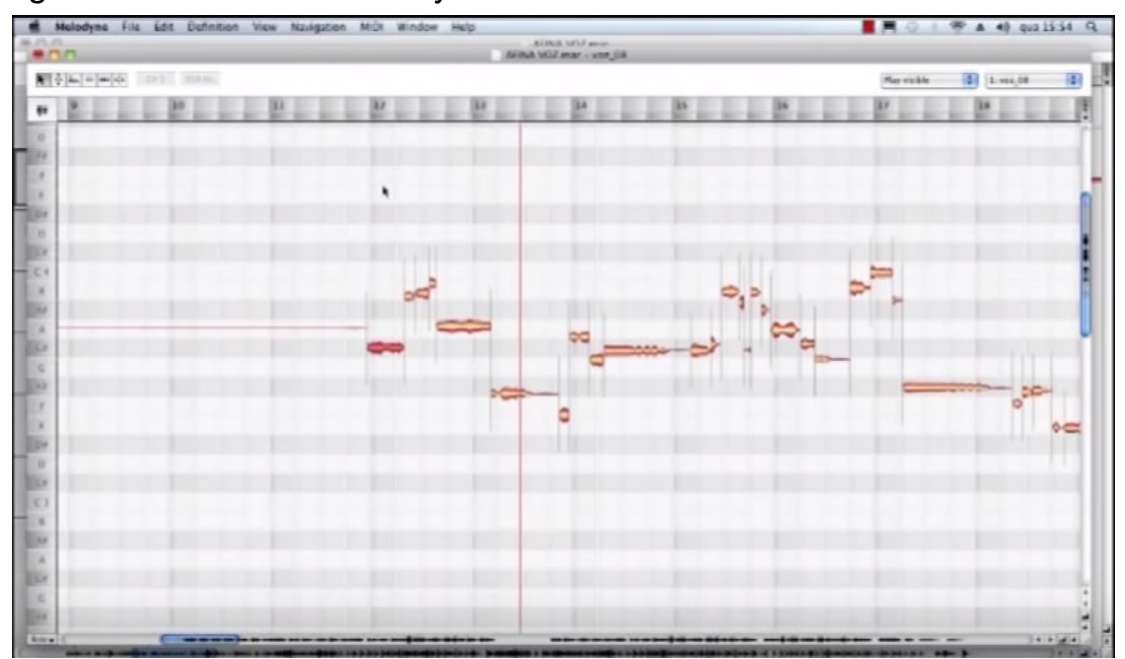

Fonte: Print screen do software Melodyne.

Outro aplicativo com função similar é o Melodyne. Diferente do AutoTune, que funciona como plug-in em outros programas, o Melodyne funciona sem precisar de outro software.

No exemplo acima, foi colocada uma faixa de voz de um cantor. As faixas brancas e cinzas representam notas musicais. É possível ver, por meio da representação visual da voz, que alguns trechos cantados não estão perfeitamente "encaixados" nas faixas. Teoricamente, o som de uma voz afinada deve ser visualmente representado de forma verticalmente centralizada nas faixas. Com um comando simples, o programa faz esse ajuste.

Ainda assim, é preciso ouvir essa faixa e conferir se as notas estão corretas. É usual que restem pequenas falhas, que podem ser corrigidas de modo manual, por ferramentas que permitem ajustes em nível detalhado, para modulação de pitch, separação de notas, entre outros.

A cultura remix, portanto, trata a mídia não como um fim, mas como ela realmente é: um meio, um espaço de troca e transporte de informações. E esse espaço não se dá somente na relação com os produtos culturais, no campo da poética, mas também no campo da técnica e dos recursos tecnológicos. $O$ 
objetivo do Auto-Tune e do Melodyne é claro: correção sonora em etapa de pós-produção. A ressignificação desse uso é resultado do potencial de apropriação e inovação típico da cultura remix, conforme será explicitado a seguir.

\subsection{Um template na rede}

Em 2008, no YouTube, o usuário americano "schmoyoho" começou a postar vídeos em seu canal, criando uma série chamada "Auto-tune The News" ("Auto-tune Notícias"). Eram vídeos que veiculavam notícias de telejornais nos EUA, transformadas em canções por meio da manipulação do áudio, acompanhadas de montagens no vídeo. Posteriormente, esse mesmo usuário criou outro formato de vídeos, que faria um sucesso muito maior, chamado "songify this!" (um neologismo que seria algo como "musicar isto!"). Trata-se de music videos, feitos a partir de fragmentos audiovisuais que circulavam na internet, desde vídeos caseiros até pronunciamentos do presidente Obama. Atualmente, o canal tem aproximadamente 700 milhões de acessos. Os mesmos mentores desenvolveram um aplicativo homônimo para smartphones, no qual o usuário pode dizer uma frase e ouvir a gravação transformada em música.

Por um lado, desenvolvedores lançaram um plug-in, a partir de uma demanda específica da indústria de produção musical. Por outro, o público respondeu com uma apropriação absolutamente inusitada dessa ferramenta, a partir do acesso aos arquivos. A grande mídia, por sua vez, reconheceu essa força. Um exemplo disso é que Schmoyoho, criador da série "Auto-Tune The News", foi contratado pela Netflix para a criação da trilha sonora de abertura da série "Unbreakable Kimmy Schmidt", série de comédia que faz diversas alusões a memes de internet em seus episódios.

Em outubro de 2014, o canal brasileiro Timbu Fun iniciou seu trabalho, em um template parecido com o de Schmoyoho: music videos cômicos, feitos a partir de diversas fontes audiovisuais, manipulados com Auto-Tune. A descrição da página diz: "O Timbu Fun cria remix irreverentes com vídeos virais da internet. A nossa melhor cantora é a Dilma". Em apenas um ano no ar, o canal já alcançou 7 milhões de visualizações contando, atualmente, com aproximadamente 40 milhões. Contudo, este não é o único canal brasileiro a realizar esse tipo de remix. O canal AutoTuneBrasil tem como objetivo 
compartilhar trabalhos do tipo, publicados em diversos outros canais, como o Faroff, responsável pelo remix "System Of A Dilma", que coloca a ex-presidente como vocalista da banda System Of A Down, enviado em outubro de 2011 (bem antes do surgimento do Timbu Fun), no momento com 3,5 milhões de acessos. Outro exemplo, ainda mais antigo, é o canal Zuare Comédia, que possui uma produção mais extensa, publicando remix desde outubro de 2010, usando o software Melodyne no lugar do Auto-tune, porém com o mesmo objetivo. O canal, hoje, possui pouco mais de 2 milhões de acessos. Atualmente os canais com maior atividade nesse tipo de remix são Timbu Fun. AtillaKw e Viradrop. 


\section{O RISO NAABERTURA DE JANELAS}

No primeiro capítulo, pudemos vislumbrar alguns aspectos da mediação tecnológica através da qual o riso se manifesta na cultura remix. Agora, é o ponto de vista do riso que nos interessa. Que aspectos tornam os vídeos analisados potencialmente cômicos?

Consideramos que é necessário analisar dois momentos: antes e depois do remix. Primeiramente, nos debruçaremos sobre a matéria-prima e perguntaremos: que tipos de vídeo costumam ser remixados, com finalidade cômica? Em seguida, pensaremos na atitude da remixagem.

Considerando a ideia de memesfera na qual os remixers estão inseridos, como é possível acrescentar elementos cômicos a um vídeo já conhecido? Há, certamente, vídeos de todos os tipos imagináveis disponíveis na rede. Mas percebemos que há, por parte dos remixers brasileiros, uma preferência pela apropriação de virais que já circulam e se tornaram conhecidos em determinados grupos, dos quais fazem parte. Geralmente são vídeos que contém pouca estrutura narrativa, muitas vezes caseiros, nos quais ocorre algo considerado pelo público como inusitado ou ridículo. Tais mídias se enquadram no que chamaremos, a partir de Tiezmann e Rossini (2013) de audiovisual de acontecimento.

Nossa pesquisa focou nesse tipo de mídia, não apenas por serem usuais nesse tipo de apropriação, mas pelo aspecto não narrativo. Consideramos curioso que vídeos com pouca narratividade tenham preferência para reelaborações - o que pode ser um indício de que a simplicidade narrativa favoreça a sua modularidade, ou seja, o seu potencial de encaixe e diálogo com mídias distintas.

\subsection{Audiovisual do cotidiano}

Tietzmann e Rossini (2013) percebem uma semelhança nesse tipo de vídeo com as primeiras exibições públicas do cinema, possibilitadas pela tecnologia do cinematógrafo - centradas na exibição do acontecimento estético e tecnológico do surgimento daquele novo meio.

Os autores afirmam que os vídeos de hoje compartilham com aqueles características em comum, como "plano único aberto, montagem reduzida ao mínimo, câmera parada, em panorâmica ou seguindo a ação, e uma temática 
fortemente calcada no registro das ações do cotidiano" (TIETZMANN e ROSSINI, 2013, p. 2).

Outra forte característica em comum é o predomínio de fragmentos autônomos em detrimento da narrativa. Cada trecho possui sua própria potencialidade de sentido, sem necessidade de desdobramento narrativo. A atitude de registrar, ler e reler esses registros audiovisuais faz parte do que os autores chamam de experiência do acontecimento.

Os autores argumentam que o cinema sofreu certa pressão para que se apropriasse de narrativas presentes em outras linguagens, como a literatura, o teatro e a ópera. Lessig (2005) acrescenta que os baixos custos de direitos autorais facilitaram a absorção pelo cinema de narrativas já conhecidas pelo público. O apelo comercial desse tipo de produção ajudou o formato narrativo a se consolidar na indústria do cinema até os tempos atuais.

Contudo, certos movimentos experimentaram um audiovisual que questionou o modelo narrativo. Tiezmann e Rossini (2013) citam como exemplos as vanguardas estéticas dos anos 20 e 30; a Nouvelle Vague francesa dos anos 60 e a popularização do videoclipe a partir dos anos 70 . É importante esclarecer que em seu surgimento, o videoclipe não se utilizava de modelos narrativos, privilegiando a junção de fragmentos.

Sobre os vídeos atuais, propõem o termo "audiovisual de cotidiano" para se referir tanto à sua natureza e conteúdo quanto ao seu consumo - pois ver e produzir vídeos passou a fazer parte do cotidiano. Sendo amparado por aparelhos eletrônicos como computador pessoal e celular, o consumo de vídeos se completa de forma externa à tela, em breves aparições, como resultado de buscas em sites e plataformas; sendo também usados como elementos de expressão em meio a conversas em redes sociais, em postagens de pessoas conhecidas, indicações, etc.

Os autores definem os seguintes princípios para esse tipo de audiovisual: brevidade (seja pela duração, restrição do meio ou por ser de consumo causal); presença de uma estrutura mínima de ação e de resolução; possibilidade de consumo individual ou por categorias e um caráter modular que facilita a reprodução, a imitação e o pastiche.

Apesar de estes autores usarem o termo "audiovisual de cotidiano", nos permitimos ampliar o recorte a partir da noção dos mesmos sobre "experiência do acontecimento", para propor o termo "audiovisual de acontecimento", visto 
que, nos remix analisados, nem sempre o original é um vídeo simplesmente cotidiano ou caseiro.

Como exemplo do exposto, citamos um vídeo intitulado "Senhora"24", disponível no YouTube, que foi alvo de inúmeros remix - dentre os quais, três utilizaram alteração do pitch e tempo da voz para propor elaborações musicais. A mídia original é o trecho de um telejornal, no qual uma repórter flagra uma senhora que passeia na rua no horário em que deveria trabalhar. $E$ então, quando percebe que foi flagrada, a senhora começa a correr. A repórter e a câmera correm atrás da senhora, enquanto a repórter repete "senhora!" correndo. Apesar de esse vídeo não ser caseiro, e sim um objeto de comunicação de massa, podemos perceber que ele é centrado no acontecimento, ou seja, em mostrar uma situação desprovida de glamour, possível de se dar no cotidiano. Existe uma narrativa de fundo, mas o trecho mais remixado é justamente o da corrida. É uma situação incomum, inusitada e hiperbólica.

De acordo com Pinheiro (2013), a hipérbole, na literatura, é caracterizada pelo excesso ou exagero de uma característica ou intensidade no desenvolvimento de uma ação, que pode ser no sentido de ampliar ou diminuir. Considerando o contexto do audiovisual de acontecimento, podemos pensar na hipérbole como um desenvolvimento muito maior (ou menor) que o esperado. Uma situação na qual se estabelece uma ironia entre o que se espera e o que acontece, que é exageradamente mais intenso que o normal. No exemplo citado, esperaríamos que a situação se resolvesse com certo constrangimento e algum tipo de evasão por parte da senhora entrevistada. O que ocorre, contudo, é o total exagero de nossa expectativa.

Outro exemplo de audiovisual não narrativo, trazido por Tietzmann e Rossini, que não é cinema ou televisão, são os jogos eletrônicos, a partir dos anos 70. Por serem consumidos na mesma plataforma que outras linguagens (o aparelho de TV), passaram a fazer parte do cotidiano do público como uma experiência audiovisual. Sobretudo até os anos 90, os jogos possuíam pouca narrativa, sendo centrados na relação entre indivíduo e máquina, estimulada por desafios repetitivos. Posteriormente, estes jogos acabaram absorvendo o modelo narrativo, até mesmo por fazerem alusões a filmes conhecidos pelo 
público. No exemplo abaixo, foi incluída a personagem "Dr. Robotinik", da franquia Sonic (SEGA), juntamente com a trilha sonora do jogo.

Figura 6: Trecho do remix "Senhora", do canal Timbu Fun

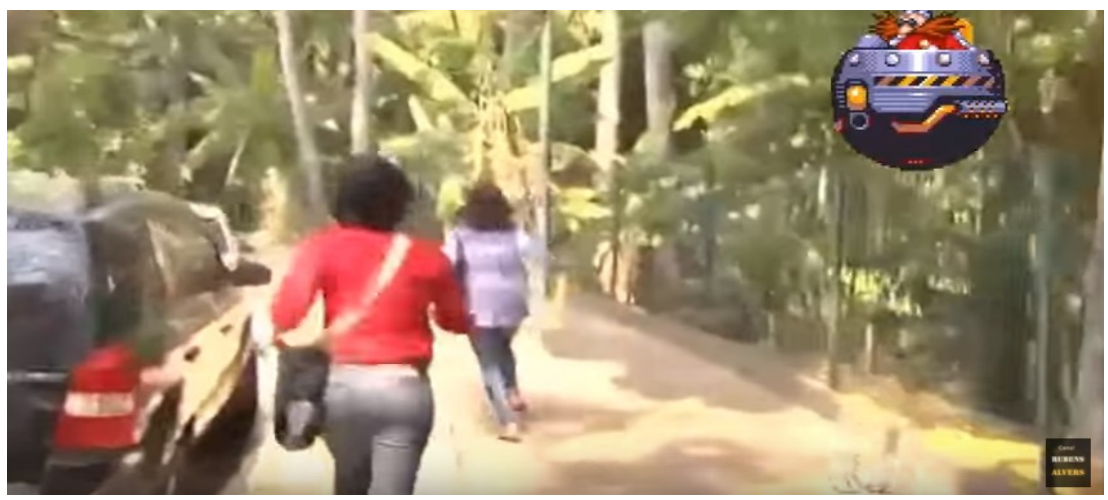

Fonte: https://www.youtube.com/watch?v=_Wl8WFm-_ZQ

Figura 7: Trecho do remix "Senhora", do canal Timbu Fun

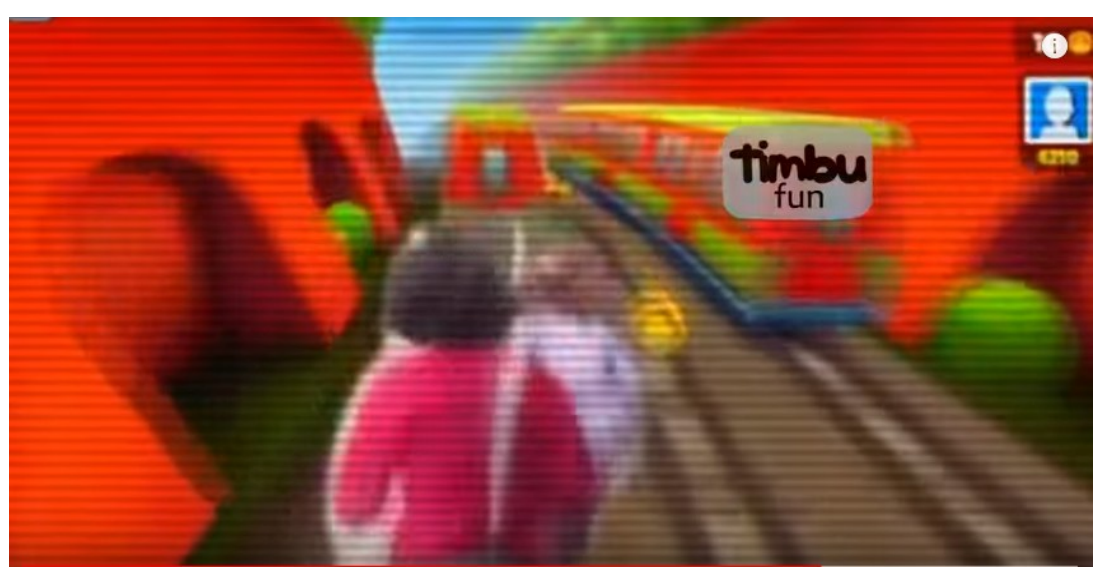

Fonte: https://www.youtube.com/watch?v=V-JqxBmEL_g

Já este outro remix, elaborado pelo canal Timbu Fun, mostra a senhora e a repórter em um cenário do Subway Surfers, um jogo desenvolvido para smartphones. Podemos perceber, conforme remix como estes, que os jogos digitais fazem parte da cultura audiovisual dos remixers e de seu público.

Os jogos digitais, ao entrarem no cotidiano, firmam uma relação entre público e obra que independe em sua raiz da qualidade da imagem como uma sugestão de indicialidade para além da tela, e desvinculam a atração da existência de uma narrativa complexa e detalhadamente estruturada. (TIEZMANN e ROSSINI, 2013, p. 6).

Muitos são os exemplos que remixam o "audiovisual de acontecimento" com elementos do universo dos jogos eletrônicos. Mas voltemos à nossa matéria-prima, os vídeos que são escolhidos para remixagem. Eles "não contam histórias; eles não têm um princípio ou um fim; de fato, eles não têm nenhum desenvolvimento temático, formal ou de qualquer espécie que 
organizaria seus elementos em uma sequência" (MANOVICH, 2001, p. 212). Muitos desses vídeos tem mais natureza de registro que de representação. Quem se encarrega de organizar e propor sequências entre esses fragmentos são os remixers.

Outra característica dessas mídias, fundamental para nossa pesquisa, é um movimento que os autores afirmam ter se tornado uma prática legítima dos canais digitais: a reedição e apropriação dos materiais como paródia ou pastiche ${ }^{25}$, facilitada pela simplicidade e modularidade ${ }^{26}$ dos vídeos publicados. Podemos supor, portanto, que o que torna o audiovisual de acontecimento atrativo para os remixers é justamente a maleabilidade possibilitada pelo não predomínio da narrativa - como suspeitamos no início deste capítulo.

Cabe esclarecer que a narrativa não é ausente nesse formato. Nos remix que analisamos, há uma pequena narrativa embutida em cada fragmento, apesar de não haver encadeamento causal entre estes. Muitas vezes o que há é uma lista de possibilidades aproximadas por semelhanças temáticas, mas não narrativas.

Figura 8: Trecho do remix "Olha eu com boné", do canal Viradrop

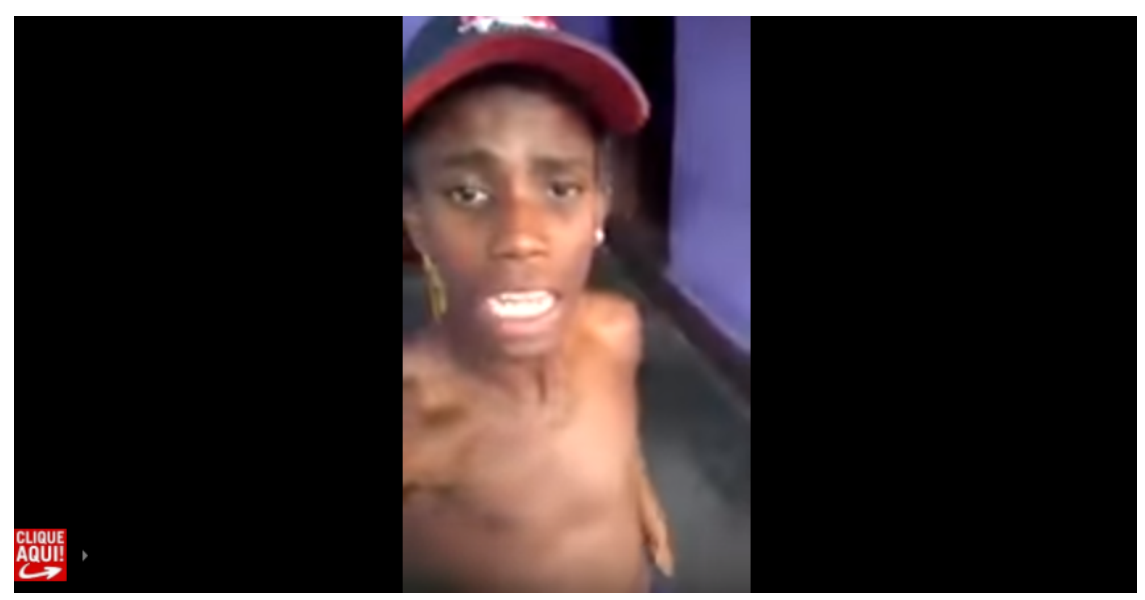

Fonte: https://www.youtube.com/watch?v=W3JAUzQjz1c

A ironia entre o que se é e o que se acredita ser é apontada por Bergson (1983) como um dos recursos da comédia. Esse mecanismo se traduz em momentos de falta de consciência de si. Um viral que pode servir como exemplo disso é o "Olha eu com boné, olha eu sem boné, kkk" no qual um

25 Esclareceremos os conceitos de paródia e pastiche nos próximos subcapítulos.

26 Definimos modularidade como a possibilidade de desmembramento de elementos de determinado fragmento para inserção em outros contextos, como peças intercambiáveis de uma estrutura passível de ser desmontada, com peças realocadas independentemente em outros locais. 
rapaz magro mostra como fica bonito (em sua opinião) com o boné que usa em diferentes posições. Em um remix do canal Viradrop (imagem acima), o rapaz canta em ritmo de funk, com diversas animações que alimentam a visualidade e humor do remix.

Não há, predominantemente, recursos de elaboração narrativa ou de criação de tramas, espaços ficcionais ou "universos". Então lançam mão do que dispõem, capturando o que surge em sua realidade de imediato, na tentativa de chamar atenção de outras pessoas.

Feitas essas considerações, podemos ter uma ideia do material usado pelos remixers para suas propostas cômicas. Nosso foco, nesta pesquisa, são os efeitos cômicos observáveis/audíveis nos remix analisados (que se colocam à disposição para fruição do público); contudo, não podemos deixar de abordar, brevemente, outro riso: o do remixer, pois isso nos ajudará a abordar de maneira contextual o surgimento desses vídeos.

Partindo de um repertório infinito de possibilidades, de um lado, e alguns templates ou modelos pré-definidos de remix, de outro, os remixers precisam fazer uma escolha fundamental: o que remixar? Hutcheon (1985) afirma que normalmente obras com muito êxito são remixadas, justamente por sua popularidade e não pela existência de traços cômicos.

O montador consegue observar determinado vídeo e perceber um potencial cômico que pode, antes da remixagem, sequer existir. Algum elemento daquela mídia, seja imagem, som ou texto, salta aos olhos como a possibilidade de algo risível. O foco dessa pesquisa não é o comportamento criativo dos remixers, contudo, podemos abordar o contexto no qual essas escolhas se dão.

\subsection{Uma atitude carnavalizante}

O conceito de carnavalização, pensado por Bakhtin e aprofundado por Minois, é um suporte para se entender o olhar cômico dos remixers sobre o objeto a ser remixado.

Bakhtin (2008) descreve o carnaval no período medieval como uma "segunda vida", experimentada pelas pessoas uma vez por ano ${ }^{27}$. Diferentemente dos outros dias do calendário do ano, nos quais o Estado e a igreja, instituições de poder da época, determinavam regras de convívio e 
comportamento, o período do Carnaval era consentido por todos os setores da sociedade (inclusive pelas instituições citadas) como um intervalo ${ }^{28}$ festivo, uma fuga provisória de regras de civilidade e conduta.

Ocorria um afrouxamento das hierarquias sociais, de modo que setores altos e baixos da sociedade eram colocados em patamares próximos, e até mesmo invertidos: em algumas representações festivas, os pobres se tornavam reis; e os donos de terra, escravos. Igreja e Estado também eram dessacralizados, e seus rituais eram alvo de toda sorte de paródias e imitações, de modo que todo o aspecto cerimonial característico dessas instituições era desfeito e levado ao ridículo. Enquanto isso, dejetos humanos eram atirados em pessoas e palavras de baixo calão proferidas até mesmo contra as divindades.

Sobre o riso carnavalesco da Idade Média, Bakhtin aponta como características a popularidade - pois o carnaval contava com a participação de todos os setores hierárquicos da sociedade, em alguns casos até mesmo os padres -, o universalismo - que diz respeito à abrangência daquilo que se ri, que poderia ser referente a qualquer coisa, de qualquer esfera privada ou pública da vida - e a ambivalência desse riso que, ao mesmo tempo, homenageia e degrada, de maneira alegre, porém sarcástica, simultaneamente negando e afirmando os aspectos oficiais da vida.

Parte da ambivalência do Carnaval está em sua natureza de representação, que oscila entre o espetáculo e a própria vida, não sendo nenhum dos dois. O carnaval era vivido corporalmente, de maneira extracotidiana, ou seja, espetacular, embora não houvesse distinção entre atores e espectadores. Todos eram atores e espectadores ao mesmo tempo (BAKHTIN, 2008).

Nesse período festivo, portanto, a sociedade era revestida de uma cosmovisão carnavalesca, caracterizada por uma concepção cômica do mundo, uma visão "oposta a toda ideia de acabamento e perfeição, a toda pretensão de imutabilidade e eternidade" (BAKHTIN, 2008, p. 9).

O carnaval funcionava, portanto, como um espaço de criatividade voltado para a ressignificação de objetos. A imaginação humana, durante aqueles dias, era livre da seriedade imposta pelas instituições para elaborar

28 Segundo Minois (2003), tal intervalo dedicado à negação das instituições seria preciso para a manutenção das próprias instituições e de tudo o que foi negado, como uma espécie de alívio necessário para a perpetuação do sistema. 
formas prazerosas, lúdicas e divertidas de zombaria. Por esse motivo, de acordo com Bakhtin, podemos afirmar que o riso carnavalesco possui força criadora.

A ideia de uma força criadora, aliada a um modo ativo de ver o mundo através de uma concepção cômica da realidade nos interessa, pois percebemos que o humor na cultura remix se desenvolve por aspectos similares. $E$ ao nos indagar o que leva um remixer a selecionar um material para remixagem e não outro, em meio a um repertório tão extenso, podemos vislumbrar que essa escolha se dá por um olhar que carrega algum tipo de impulso carnavalesco, no sentido de conceber a vida como algo passível de ressignificações cômicas.

Essa concepção cômica da vida nos remix analisados se inicia antes mesmo da seleção das mídias a serem remixadas, mas também na apropriação subversiva dos softwares. Os remixers "dessacralizam" a função "original" do Auto-Tune e do Melodyne, de maneira irreverente, para brincar.

\subsection{O grotesco e o insociável}

Acreditamos ser enriquecedor para essa discussão trazer à tona reflexões sobre um aspecto que parece recorrente nas piadas que circulam na rede e na mídia em geral - a ideia de insociabilidade, sobretudo no que tange à categoria estética do grotesco. Vídeos de acontecimento com traços grotescos nos parecem os preferidos pelos remixers.

Bergson (1983) demonstra que o riso possui uma certa função social de corrigir comportamentos que a sociedade considera inadequados. Por exemplo, não se espera de uma pessoa que está esperando ônibus que, distraída, comece a dançar. Espera-se que, mesmo que tenha vontade de dançar, controle-se, pois dançar não seria socialmente razoável nesta situação. $E$, caso incorra nesse "erro", será submetida à humilhação do riso. A maioria dos remix que analisamos se apropria de vídeos cujo principal acontecimento é um comportamento tido como inusitado, inadequado. Isso explica porque a mesma piada pode fazer pessoas rirem em um país e não em outro: os costumes são diferentes. O mesmo vale para diferentes grupos ou comunidades dentro de uma mesma cidade.

Para desenvolver seu raciocínio, Bergson defende que de modo geral, a vida do ser humano seria como uma grande máquina, com padrões a serem 
seguidos, sistemas de valores intercambiáveis e movimentos repetitivos ao longo da sua existência. Entretanto, há um paradoxo: as pessoas que habitam essa sociedade não podem se comportar de modo mecânico. Precisam ser flexíveis e atentas a qualquer imprevisibilidade. O autor aponta a tensão e a elasticidade como forças necessárias ao convívio social. Afirma que a vida exige das pessoas um esforço constante de adaptação a diversas situações e atividades cotidianas. É necessário haver certa flexibilidade do corpo, espírito e atenção para não reagir aos acontecimentos de modo "mecânico".

A sociedade, enquanto sistema, preza para que não haja desvios, comportamentos que ameacem a "harmonia" da vida social. Quaisquer comportamentos que indiquem um "adormecimento" ou isolamento do indivíduo em relação ao todo é considerado um gesto ameaçador dessa harmonia, que como reação, gera por parte da sociedade um outro gesto social: o riso, que nessa perspectiva funciona como ferramenta de "correção":

$\mathrm{O}$ riso é, antes de tudo, um castigo. Feito para humilhar, deve causar à vítima dele uma impressão penosa. A sociedade vinga-se através do riso das liberdades que se tomaram com ela. Ele não atingiria o seu objetivo se carregasse a marca da solidariedade e da bondade. (BERGSON, 1983, p. 92)

Por exemplo, se rimos de uma pessoa que cai, caminhando na rua, não rimos da queda em si, mas do fato de que percebemos que a pessoa acreditava que continuaria andando. Ela se deparou com um imprevisto e não teve atenção ou flexibilidade para superá-lo. Ou seja, ela agiu com incapacidade de responder adequadamente, com desatenção e rigidez, de forma mecânica - diferente de como a sociedade espera que se comporte.

Desvios como esse são comuns. Considerando a sociedade como máquina, a pessoa que cai é como uma peça que saiu do lugar ou não funciona corretamente. Quando esses erros acontecem, o ser humano revela o seu lado maquinal. As pessoas não podem parecer máquinas, portanto, esse erro precisa ser corrigido. A ferramenta de correção para esse desvio, segundo o pensamento do filósofo, portanto, é o riso. Quando alguém se desvia, há uma "descontração", ou seja, um descuidado. Essa descontração, esse "defeito na máquina", segundo o autor, é o objeto da comédia.

É muito importante esclarecer, que na visão desse pensador, o mecânico deve estar de fato calcado no vivo, ou seja, precisa parecer vivo, espontâneo, e não apenas mecânico. Para que o riso aconteça, é preciso que o mecânico e o 
vivo estejam em um corpo só: "É cômico todo arranjo de atos e acontecimentos que nos dê, inseridas uma na outra, a ilusão da vida e a sensação nítida de uma montagem mecânica" (BERGSON, 1983).

Outro aspecto importante abordado pelo autor: quem ri não sente compaixão, tampouco se identifica. Se alguém sofre à nossa frente, seja uma personagem ou ser da vida cotidiana, jamais nos emocionaremos e riremos de sua condição concomitantemente. Podemos até transitar de um estado a outro, mas nunca sentiremos as duas coisas ao mesmo tempo. O riso é de ordem racional, fria, ao passo que a identificação e a compaixão são de uma ordem oposta, ou seja, emocional. Esses dois extremos são os campos onde operam a comédia e o drama. "Insociabilidade do personagem, insensibilidade do espectador, eis, em suma, as duas condições essenciais" (BERGSON, 1983, p. 77).

Feitas essas considerações sobre o riso, voltemos à nossa matériaprima. Parte dos vídeos de acontecimento remixados possuem uma estética tosca. Muitas vezes, são gravados com câmeras simples que deixam a imagem pouco nítida. Tampouco há cuidado técnico na iluminação e captação de som, falta ainda cuidado nos enquadramentos.

As fronteiras que separavam tão claramente produtores de espectadores se diluíram faz tempo; agora o que se dilui são as próprias formas estéticas estabelecidas como marco do bom gosto, da transgressão ou do acomodamento (TIETZMANN e ROSSINI, 2013, p. 15).

O grotesco, então, vai de encontro ao que é considerado como esteticamente adequado, provocando, além do riso, a repulsa, o espanto e o horror. O grotesco opera rebaixando o ser humano a aspectos insociáveis, ligados não somente ao inadequado, mas ao "feio".

Bergson também aborda a questão do riso ligado à ideia de feio, tanto no sentido físico quanto de caráter ou comportamento. Afirma que é possível rirmos de defeitos leves de nossos semelhantes. Argumenta que o contrário da feiúra não é a beleza e sim a graça, a harmonia. Bastaria causar um desarranjo na harmonia, um ruído, uma "feiúra", para se obter o riso. Esclarece, contudo, que o riso não ocorre somente pelo rebaixamento grotesco, mas por outras transposições. Por exemplo, rimos do feio que se acha belo, mas o contrário, segundo o autor, também é possível. Uma qualidade moral também pode ser risível: uma virtude inflexível, intensa a ponto de se tornar insociável, inadequada, suspeita à sociedade. 
Apesar de o grotesco enquanto repulsa e horror não ser tão popular na rede atualmente, percebemos, a partir da leitura dos autores citados, que algumas características são constantes nos produtos audiovisuais de entretenimento produzidos no Brasil, como esclareceremos adiante.

Há muitos remix envolvendo vídeos de crianças. Isso não nos surpreende, pois é comum rir de crianças, pelo fato de que elas ainda não aprenderam os códigos de comportamento esperados pela sociedade. Por não ter esse "filtro", acabam por quebrar as regras de sociabilidade espontaneamente, suscitando o riso dos adultos. Em 2012, viralizou um trecho do telejornal "Boa Tarde Paraná", no qual um menino chamado José afirma para a repórter que está "cagado de fome". Na figura abaixo, temos um frame do remix proposto pelo canal Viradrop para o vídeo.

Figura 9: Trecho do remix "Tô cagado de fome", do canal Viradrop

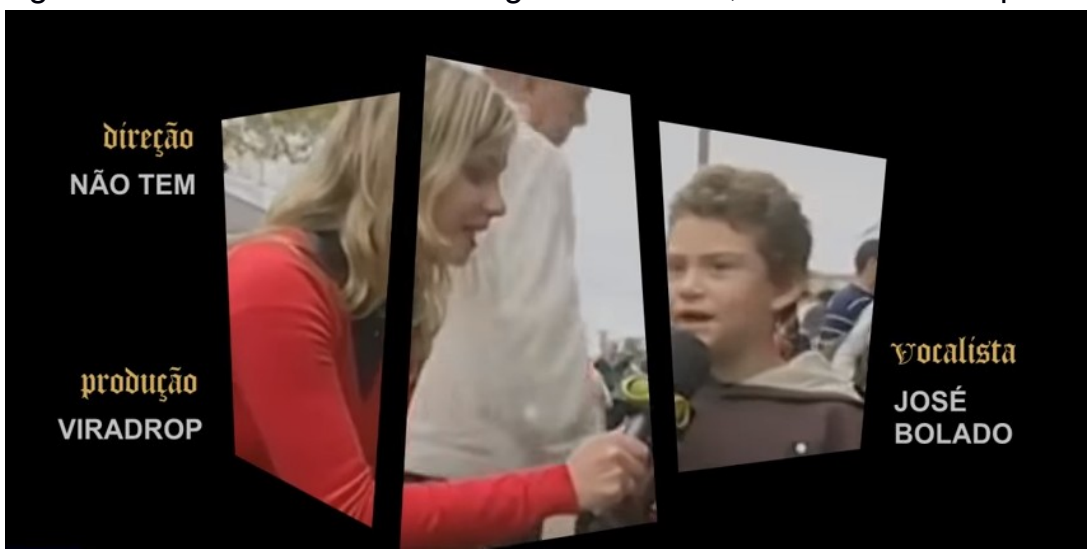

Fonte: https://www.youtube.com/watch?v=WWe6ZPo6z-4

O exemplo exposto nos serve não apenas para ilustrar a questão da insociabilidade do comportamento, mas também outra característica do grotesco bastante presente no audiovisual contemporâneo: a alusão ao baixo corporal - tal como no carnaval medieval. São nossas necessidades fisiológicas e instintivas: escatologia, comer e beber, impulsos sexuais, doenças, deformidades físicas, etc.

Um exemplo de baixo corporal ligado aos atos de comer/beber é um vídeo publicado em fevereiro de 2013 , no qual um senhor interrompe uma entrevista para gritar que quer café, repetidas vezes. Abaixo, um trecho do remix proposto pelo canal Timbu Fun para esse viral. As legendas foram propostas pelos remixers. 


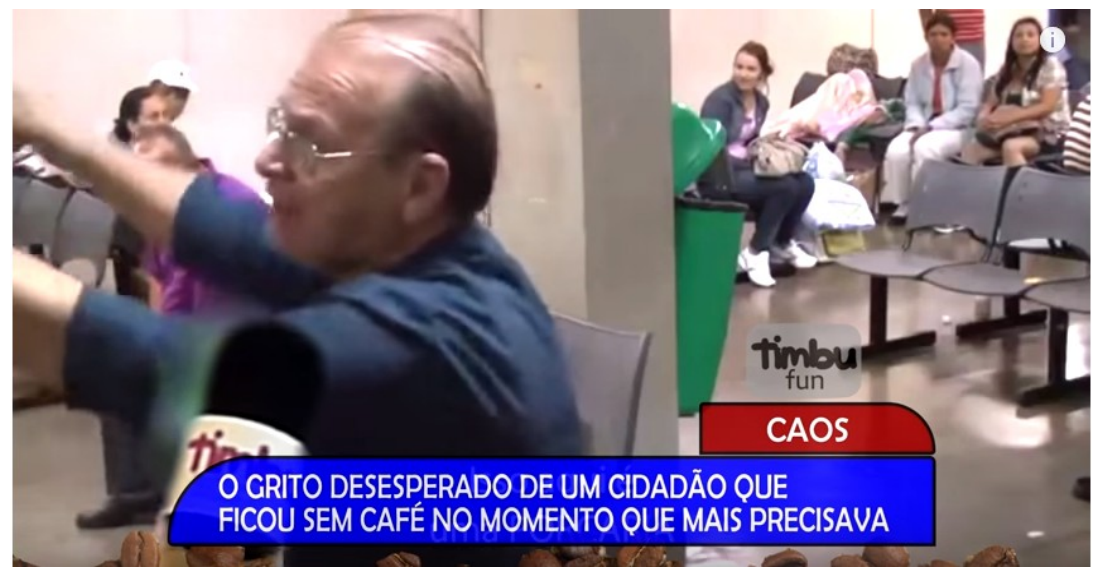

Fonte: https://www.youtube.com/watch?v=X0_Rj7hmvFc

O baixo corporal ganha força cômica quando em oposição ao alto corporal, correspondente à cabeça: o plano das ideias, as virtudes morais, a espiritualidade - ou seja, o que a sociedade considera nobre, aquilo que ela persegue em seu esforço de manter uma harmonia, de acordo com seus códigos.

A mitologia bíblica nos ajuda a entender as ideias de alto e baixo a partir do mito de Adão e Eva. Ao comerem do fruto proibido, eles perceberam que estavam nus e foram expulsos do paraíso. No paraíso, então, haveria apenas o alto corporal, ou seja, aquilo que torna os seres humanos diferentes dos outros animais. Perceber a "impureza", reconhecer a própria animalidade, a própria nudez é se dar conta do baixo corporal. Minois (2003) pontua diversos momentos na história medieval nos quais o riso foi condenado ou até mesmo proibido. Este autor, para nos fazer entender como a igreja via o riso, nos lança a pergunta: Jesus riu? Realmente, muitas autoridades da igreja acreditavam e pregavam que Jesus não poderia ter rido. Talvez um riso amigável, um riso espirituoso, mas não o de zombaria, jamais uma gargalhada. Lembrando o pensamento de Bergson: quem ri não sente compaixão. Jesus também representa o alto corporal, as virtudes espirituais, a humanidade, a sabedoria. Minois nos ajuda a perceber que, entre as ideias mitológicas de céu e inferno, o lugar do riso (e do baixo corporal) é certamente o segundo.

A referência do grotesco ao baixo corporal é uma derivação do tema da animalidade. O animal se guia pelos instintos, prezando pela conservação de si, enquanto o homem, além disso, acrescenta a "as questões essenciais do sentido e do valor, que o levam a busca poética da transcendência e a dirigir o seu desejo para valores e ideais" (SODRÉ e PAIVA, 2002, p. 50). Desse modo, 
ao rebaixar o ser humano ao aspecto animal, ligado a uma natureza instintiva, sexual, violenta e escatológica, distanciamos o mesmo das virtudes intelectuais. O corpo grotesco, portanto, encontra sua natureza entre o humano e o animal.

Bergson (1983) afirma que o riso é um ato essencialmente humano. O homem é o único animal que ri e o único que faz rir. Se por algum motivo se ri de um chapéu, de um cachorro ou de uma árvore, é porque a imagem despertou a lembrança de algo de humano. Ou seja, não há nada de engraçado nos animais. A animalidade grotesca torna risível o homem, ao "rebaixá-lo" à condição de animal.

Em nossas pesquisas por "audiovisual de acontecimento" cômico, nos deparamos com incontáveis páginas e canais de enorme repercussão, voltados exclusivamente para a divulgação de vídeos cômicos de animais domésticos, remixados e transformados em memes. Como exemplo, podemos citar a página "Catioro Reflexivo"29", na plataforma Facebook, com 4,4 milhões de seguidores; e o canal "Tiger FunnyWorks", no YouTube ${ }^{30}$, com 934 mil inscritos. Citamos esse tipo de trabalho não para exemplificar o grotesco, até porque "o grotesco funciona por catástrofe" (SODRÉ e PAIVA, 2002, p. 25), ou seja, necessariamente pelo rebaixamento. Citamos esses exemplos pela razão contrária, conforme o pensamento de Bergson que citamos anteriormente: o cômico não se estabelece somente pelo rebaixamento, mas pela transposição, que pode ter o vetor no sentido inverso, ou seja, de elevação. O que percebemos nesse tipo específico de audiovisual é a elevação do animal ao status de humano - em diversos comportamentos que seriam considerados insociáveis, caso humanos fossem.

Além do baixo corporal, há ainda outro aspecto pensado por Bergson em relação ao corpo. Afirma que "é cômico todo incidente que chame nossa atenção para o físico de uma pessoa estando em causa o moral" (BERGSON, 1983, p. 33). Ou seja, é risível que uma pessoa que tenta exibir uma virtude moral seja atrapalhada pelo próprio corpo, como, por exemplo, um orador espirra no ápice de seu discurso. Sapatos apertados, dor de dente e sensações de calor e frio são outros exemplos. Daí a razão de muitos tímidos serem cômicos: o tímido parece ter um corpo que o incomoda.

29 Disponível em: https://www.facebook.com/CatioroReflexivo/ 30 Disponível em: https://www.youtube.com/user/wloltigerlolw3/about 
Além dos aspectos da insociabilidade, baixo corporal e animalidade, há no grotesco um aspecto onírico. Ele e assemelha às fantasias produzidas pela imaginação, como "um jogo de máscaras ou uma representação caricatural (...), podendo assumir formas fantásticas, horroríficas, satíricas ou simplesmente absurdas" (SODRÉ e PAIVA, 2002, p.55).

Em seus estudos sobre o riso, Bergson também aborda o onírico. Afirma que o pensamento cômico é influenciado pela lógica da imaginação. A lógica do risível tem algo de semelhante com a do sonho ou do devaneio. "É fácil de ver, com efeito, que todo jogo de ideias poderá nos divertir, desde que nos lembre, de perto ou de longe, os jogos do sonho." (BERGSON, 1983). A razão fabula, criando universos de lógicas diferentes da realidade. Quando há um desvio da lógica da realidade para a lógica do sonho, pode-se ter uma situação risível. Podemos citar como exemplo da literatura clássica as alucinações da personagem Dom Quixote. São desvios cuja causa conhecemos: a excessiva leitura de romances de cavalaria.

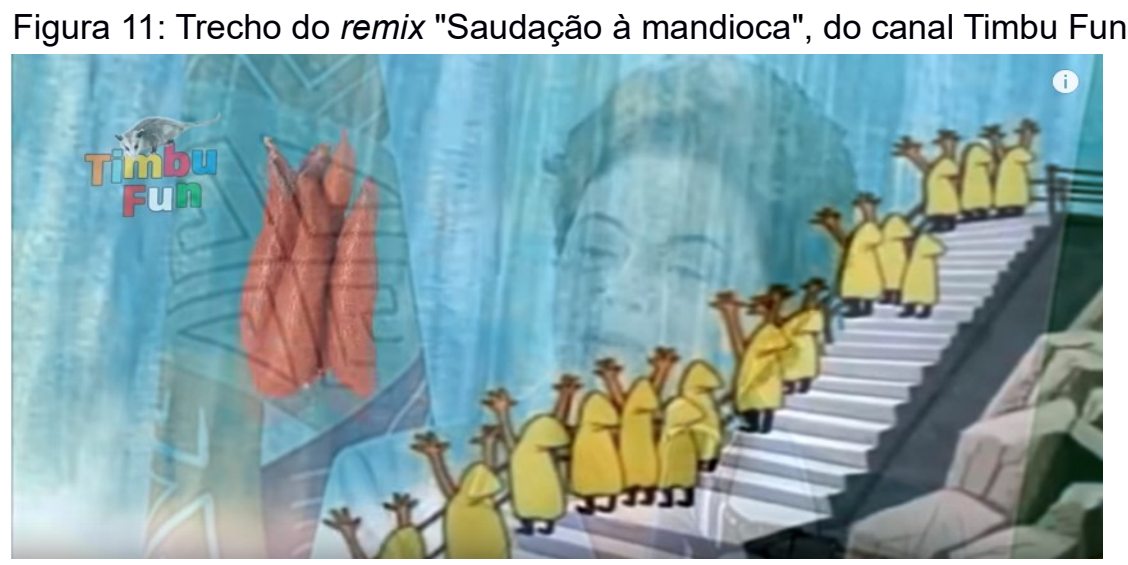

Fonte: https://www.youtube.com/user/Timbu Fun

$\mathrm{Na}$ lógica da razão, não faz sentido que uma presidenta da república faça uma "saudação à mandioca", em um discurso público ${ }^{31}$. Esse acontecimento, inusitado, tem potencial cômico por si só. A fim de acentuar sua comicidade, basta deslocar esse acontecimento para uma moldura lúdica, ou seja, para a lógica da imaginação. Isso ocorre no remix "Saudação à Mandioca", do canal Timbu Fun, no qual essa situação se dá na forma de canção, em um music video.

Bergson fala também em "verossimilhança", no sentido que a comédia deve evocar imagens que pareçam espontâneas e naturais. Contudo, é preciso pensar que seus escritos datam de antes do advento das TIC, e que hoje, 31 Essa fala se deu em discurso de Dilma Roussef no lançamento dos Primeiros Jogos Mundiais dos Povos Indígenas, em junho de 2015. 
imagens eletrônicas também nos são familiares. Portanto, mesmo um vídeo em looping, cujo movimento das imagens é nitidamente mecânico, pode parecer cômico. Afinal, como também defende o autor, é risível a imagem de um corpo humano que nos faça lembrar de um simples mecanismo, ou mesmo de uma pessoa que pareça ser uma coisa.

\subsubsection{O grotesco no audiovisual brasileiro}

Segundo Sodré e Paiva (2002), o grotesco esteve presente no cinema brasileiro dos anos 40 a 60, em uma linha de comédias que ficaram conhecidas como "chanchadas", influenciadas pelo teatro burlesco e marcadas pela palhaçada e pela ridicularização paródica do cinema hollywoodiano ou outros, tidos como muito sérios.

O grotesco se afastou do Cinema Novo, mas voltou e permanece presente contemporaneamente, não apenas no cinema, mas na TV, em programas de apelo popular que esgarçam aspectos de miséria humana, brigas, curiosidades relacionadas à aberrações da natureza, imagens de aleijões, imagens de apelo sexual, manifestações de idiotia, deformidades, etc.

Situações "estapafúrdias, ridículas ou constrangedoras" (SODRÉ e PAIVA, 2002, p. 104) são focos das chamadas "pegadinhas", presentes em diversos programas de televisão brasileiros como Festa do Malandro (TV Gazeta), Topa Tudo por Dinheiro (SBT), Domingão do Faustão (Rede Globo), entre outros, nas quais pessoas se submetem a situações embaraçosas.

Considerando a heterogeneidade da TV enquanto meio de comunicação e as mudanças ocorridas com o passar do tempo, os autores colocam que a televisão brasileira passou por três fases: primeiramente, a televisão massiva (homogeneizante), depois a televisão segmentada, caracterizada por financiamento variado (pay-per-view, TV por assinatura, etc); e finalmente a televisão interativa, que considera não apenas a TV Digital, como o conteúdo de televisão que pode ser acessado de diferentes dispositivos e com diferentes serviços, como YouTube, TV "on demand", etc.

Os autores também mostram a proximidade entre alguns programas de TV e a praça pública. A televisão massiva, especialmente no que concerne aos programas de auditório, é caracterizada por uma atmosfera sensorial que remete à praça, na qual pode-se ver expressões diversas da cultura popular, desde variedades espetaculares, tais como apresentações musicais, dança ou 
circo, e mesmo opiniões sobre temas sociais como violência e cotidiano. A existência desse tipo de atração em praça pública já existia na Europa, desde o renascimento até o século dezessete, onde podia-se assistir a encantadores de serpentes, contadores de histórias, vendedores, músicos e outras atrações. No Brasil, os autores ressaltam as feiras nordestinas, com seus camelôs, repentistas e literatos de cordel. Afirmam que essa aproximação com a praça pública foi uma estratégia consciente, desde os programas de auditório radiofônicos.

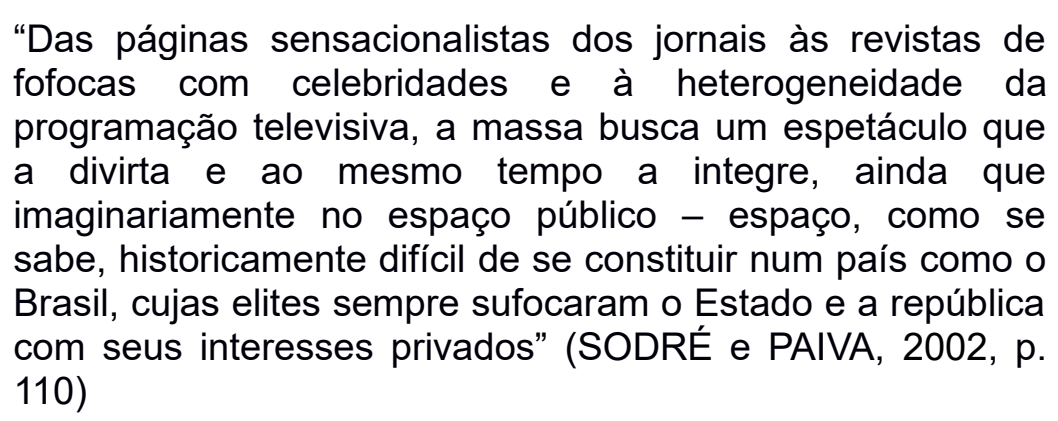

Entre o telejornalismo e o entretenimento, temos o surgimento de um tipo de programa televisivo que se usa muito do grotesco: os reality shows. Como exemplo mais popular, o Big Brother Brasil, da Rede Globo, desde 2002 cria apelo de audiência pelos desentendimentos entre participantes e relações sexuais - ou seja, o foco desses programas é o baixo corporal. Um exemplo específico que se aproxima do grotesco chocante é a "prova do líder", quadro do Big Brother Brasil no qual os participantes são submetidos a grandes provações físicas.

De modo geral, o grotesco, na TV, é comumente ligado ao "apelo" pela audiência. Em julho de 2014, a emissora Multishow lançou o programa "Tudo Pela Audiência”, uma sátira a programas de auditório brasileiros. O programa é fortemente caracterizado pelo grotesco, sobretudo em relação ao apelo sexual. Programas como Ratinho e Casos de Família, da emissora SBT, exploram o grotesco pela desavença entre pessoas de baixa renda.

Antes da televisão, Sodré e Paiva também informam que no Brasil, as elites republicanas se identificavam com o padrão de vida europeu, não manifestando interesse em personagens, que na Literatura, representassem camadas sociais menos favorecidas. Contudo, somente apreciavam caso essa representação fosse ridicularizada, como a personagem Jeca Tatu, de Monteiro Lobato. 
Assim como em Jeca Tatu, os autores afirmam que as representações sociais são objeto da programação da TV aberta. Argumentam que essas representações muitas vezes incorrem pela ótica do grotesco. Os programadores de conteúdo partem do conhecimento do senso comum sobre os grupos sociais, para criar representações com conteúdos, opiniões e informações sobre a vida cotidiana. $\mathrm{E}$ a formatação desse conteúdo tem como objetivo captar a atenção, para que seja lido com facilidade.

A TV reinterpreta, dessa forma, discursos do senso comum de modo acessível ao público. Esse tipo de representação, segundo os autores, privilegia a ótica do grotesco, também por suscitar o riso cruel e o grotesco chocante, que encena o povo chamando atenção da audiência, que se mantém distante desse objeto risível.

Bergson (1983) acrescenta que é cômico simplificar uma personagem em função de poucas características. Assim é feito com a representação de classes sociais de forma ridicularizadora, pela ótica do grotesco: esses personagens são desumanizados, na medida em que sua complexidade não é representada.

Os autores também alertam para a recorrência, em diversos programas televisivos, de sorteios de prêmios diversos, como apelo à audiência no sentido de oferecer um alívio para a falta de humanidade, como que para atribuir à imagem das emissoras uma certa característica benevolente. Por meio de sorteios, é possível deixar nas mãos do destino e da providência o bem estar de pessoas pouco favorecidas economicamente, conforme disposição dos patrocinadores. Para além de sorteios, há também os programas destinados a oferecer transformações nas vidas das pessoas, seja por uma mudança de visual ou pela reforma de sua casa ou carro.

Estudar as características do grotesco na televisão nos parece importante no sentido de compreender a cultura audiovisual que está por trás das escolhas de remix, atualmente. Observamos recorrência de vídeos remix que se apropriam da pobreza para ridicularizar essas representações. A imagem a seguir, é de trecho do remix "Eu sou o Dougras", que mostra um rapaz banguela, negro e em um cenário humilde. O remixer tenta, dessa maneira, suscitar o riso explorando a imagem ridicularizada de um indivíduo pertencente a uma classe social desfavorecida. 


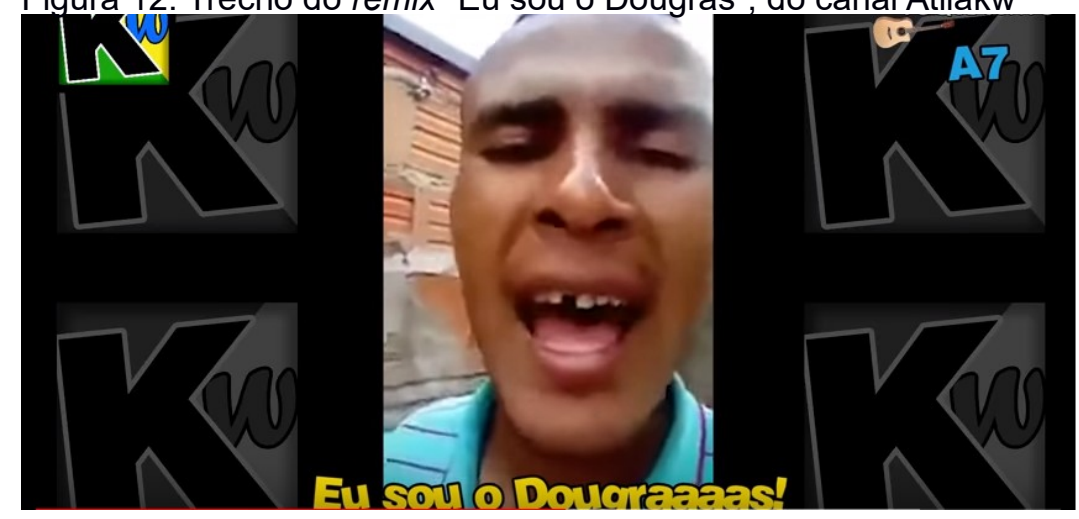

Fonte: https://www.youtube.com/user/atilakw

Muito do humor que se desenvolvia no Carnaval e no audiovisual brasileiro pode ser considerado como grotesco. Expandir o conceito que o senso comum tem sobre o termo foi importante para conseguir olhar para 0 panorama contemporâneo e entender que esse tipo de humor se manifesta fortemente na maior parte dos remix analisados.

\subsection{Bissociação e justaposição}

Conceitos como carnavalização e grotesco nos ajudam a compreender aspectos importantes de nosso objeto de estudo. Agora abordaremos um aspecto técnico, ligado à manipulação executada pelos remixers. Um remix audiovisual pressupõe um processo de montagem, que pode abranger combinações inusitadas entre imagens e sons, que podem ter potencial para provocar o riso. A seguir, algumas reflexões sobre como essas combinações podem ocorrer, para além do fazer audiovisual.

O humor, segundo Koestler (1964), se dá no encontro mental entre dois blocos de significação independentes, aparentemente incompatíveis, gerando um conflito. Nesse confronto, o pensamento se separa da emoção, e esta resolve-se em riso. O autor afirma que uma anedota será bem-sucedida se mantiver a sua coerência até o momento da "surpresa", que carrega a colisão.

Para Bergson (1983), um dos recursos da comédia é o que ele chama de "interferência de séries". Ela funciona pela combinação de dois fatores: independência e coincidência. Sendo a vida, na comédia, tomada como um corpo mecânico, um sistema de ações e relações formado por peças intercambiáveis, essa técnica consiste em inverter peças ou transportar blocos de significação entre sistemas que coincidam parcialmente. 
$\mathrm{Na}$ literatura, podemos exemplificar o exposto com o quiproquó. Dois ou mais blocos de personagens, cada um acreditando em uma versão da história, entram em conflito, pois entre as duas visões há uma série de coincidências que faz com que, parcialmente, cada uma das duas aparente ser verdadeira. O espectador, por sua vez, se diverte, pois sabe melhor que todos os personagens o que está acontecendo. Além do quiproquó, existem diversas outras formas de interferência de séries, em qualquer situação na qual, mediadas por alguma coincidência parcial, duas situações independentes se intercambiem. Além do quiproquó, Bergson também sinaliza a possibilidade de comicidade no confronto entre diferentes tempos da mesma história, na qual presente e passado pareçam coincidir.

No caso dos remix analisados, a montagem provoca a interferência de séries. Fragmentos de origem diversa e significados independentes se combinam mutuamente, de modo que conseguimos reconhecer a sua origem (independência) e ao mesmo tempo ler o novo sentido formado a partir da justaposição (coincidência). Esses fragmentos podem ser músicas, ruídos, trechos de filmes ou de programas de TV, vídeos caseiros, memes, enfim, tudo o que interessar ao universo temático do remix.

De modo geral, temos duas situações independentes: de um lado, uma situação gravada em vídeo, e de outro, uma canção composta para fazer rir. Quando um software como o Auto-Tune consegue fazer as duas coisas coincidirem por meio da montagem, obtém-se o riso: "Uma situação será sempre cômica quando pertencer ao mesmo tempo a duas séries de fatos absolutamente independentes, e que possa ser interpretada simultaneamente em dois sentidos inteiramente diversos." (BERGSON, 1983).

Eisenstein (in CAMPOS, 1984) compara a montagem cinematográfica a ideogramas - combinações de hieróglifos na cultura chinesa. Diferente de nossa escrita alfabética, composta por somas de letras sem sentido em si ( $b+a=" b a ")$, hieróglifo é resultado da junção de duas imagens, logo as palavras são formadas a partir da combinação de dois signos descritivos distintos. Por exemplo, um hieróglifo correspondente à "boca", se unido a outros, podem gerar diversos sentidos: se associado a "cachorro" significa "latir"; se associado a "criança", significa "gritar", se a "pássaro", "cantar". O autor defende que esse processo de associação entre signos é uma forma primitiva de montagem. 
Essa comparação diz respeito à técnica da justaposição. Quando escolhas (entre fragmentos de som e de imagem) são feitas em um processo de montagem, seja em remix ou qualquer outra forma de produção audiovisual, ocorre um tipo de associação de ideias parecida com a dos ideogramas. A justaposição de um som a uma imagem pode modificar totalmente o sentido da primeira. Eisenstein (2002) define a justaposição da seguinte forma: "O fragmento $A$, derivado dos elementos do tema em desenvolvimento, e o fragmento $B$, derivado da mesma fonte, ao serem justapostos fazem surgir a imagem na qual o conteúdo do tema é personificado de forma mais clara" (EISESTEIN, 2002, p. 18). Tal resultado, obtido a partir da justaposição, não é uma soma de significados, e sim um produto, visto que é qualitativamente diferente dos dois fragmentos anteriores.

Desse modo, para abordar montagens audiovisuais, é preciso levar em consideração não apenas o potencial de cada fragmento utilizado e as técnicas de unificação (ou seja, os métodos de montagem), mas tomar como ponto de partida o produto final, que é mais que uma mera soma de fragmentos e técnicas. Dessa forma, cada fragmento pode ser analisado como parte de um todo, como uma representação particular de um tema geral. Em nosso caso, começamos a análise pelo remix, analisamos cada elemento inserido (como, por exemplo, um meme), como representação particular do tema do remix.

A necessidade da exposição coerente e orgânica de um tema é, para Eisestein (2002) o objetivo da montagem. Os temas dos remix analisados giram em torno do humor, portanto, um remix que se pretenda cômico pode ter, em sua montagem, colisões inusitadas entre diferentes blocos de significação.

Modesto Carone, na obra "Metáfora e Montagem" (1974) afirma que a montagem, ao colocar em diálogo diferentes fragmentos, cria entre eles uma relação conceitual e metafórica. Se o fragmento A é associado ao fragmento $B$, há uma contaminação de significados, assim como no exemplo dos ideogramas (que, para Carone, são "metáforas visuais"). Ou seja, A "significa" B, e B "significa" A. Um é conceito do outro; um é metáfora do outro.

Dentre as diversas fontes de fragmentos utilizadas para os remix em questão, estão os memes externos à mídia original. Um vídeo que se tornou viral pode ser remixado, sendo colocado em diálogo com diversos outros memes que possuam relação com o tema. Veremos alguns exemplos no terceiro capítulo. 


\subsection{A escolha do gênero musical}

Um elemento fundamental na elaboração dos remix analisados é a música. Em todos, há a proposição de uma melodia, que entra em colisão com o contexto do vídeo original. Percebemos que o gênero musical escolhido, em cada caso, tem grande participação na elaboração do produto final e no modo como o cômico é suscitado. A seguir, algumas reflexões sobre as escolhas em torno desses gêneros.

Os vídeos analisados nesse estudo foram publicados por três canais: AtillaKw, Viradrop e Timbu Fun. Cada um dos três canais tem suas características próprias, ao mesmo tempo em que utilizam técnicas em comum. Uma das maiores diferenças entre eles é a escolha do gênero musical, relevante, do ponto de vista cultural, para que a piada surta efeito ou não. Como bem aponta Bergson (1983), o riso depende dos códigos culturais estabelecidos em cada sociedade. E ao propor essa análise, levamos em consideração que os diferentes gêneros musicais se articulam em nossa sociedade, e são culturalmente associados a tribos urbanas, classes sociais ou mesmo expressões religiosas.

Cada gênero sugere, de forma estereotipada, um universo cultural ou grupos sociais ao qual estão simbolicamente atrelados. A ideia de estereótipo nos é cara, pois a comédia, segundo Bergson (1983), usa de arquétipos e estereótipos. Enquanto o drama foca nos detalhes, no indivíduo e em seus aspectos psicológicos, a comédia amplia essa visão para um panorama geral, que abrange a sociedade, dividindo-a em arquétipos sociais.

O herói de tragédia é uma individualidade peculiar em seu gênero. Poderá ser imitado, mas nesse caso se passará, conscientemente ou não, do trágico ao cômico. Ninguém se parece com ele, porque ele não se parece com ninguém. Já pelo contrário, um notável instinto leva o autor cômico, ao compor o seu personagem central, a fazer gravitar em torno dele outros figurantes que apresentem os mesmos traços gerais. Muitas comédias têm por título um substantivo no plural ou um termo coletivo. "As Mulheres Sábias", "As Preciosas Ridículas", "O Mundo do Tédio" etc. (BERGSON, 1983, p. 78)

Tal reflexão nos leva a acreditar que tomar um gênero musical de forma estereotipada, pode ser interessante elaborar remix com finalidade cômica. Para Bergson, a ideia da interferência de séries indica que quanto maior a 
desarmonia entre uma situação e outra, maiores as possibilidades de se obter o riso.

É preciso considerar também que há, no Brasil, alguns gêneros musicais que costumam trazer, em suas letras, alguma dose de humor. É o caso de alguns sambas, funks e sertanejos universitários, por exemplo. O canal AtillaKw prioriza esses gêneros, investindo em propostas que incentivam o riso pela afirmação do potencial cômico dos arranjos e melodias. Nesse caso, o remixer aproveita o estereótipo bem humorado do gênero musical.

Já no canal Viradrop, o que ocorre é o inverso. A maioria dos remix são feitos com música eletrônica, dubstep, pop e psy-trance, característicos das raves e festivais de música eletrônica. Nesse caso, o encaixe entre uma situação cômica, contida no vídeo original, e um gênero musical "sério", causa um contraste que provoca o riso justamente por esse paradoxo.

O canal Timbu Fun aposta em uma diversidade ampla de gêneros, indo do arrocha ao heavy metal. Contudo, há muita clareza na estereotipação dos gêneros, que conduz o arranjo cômico entre música, texto e imagem.

Nos exemplos analisados, considerando os dois sistemas independentes (canção e discurso oral), percebemos que na coincidência entre ambos, ocorre, em cada um, um desvio. Por um lado, há a representação arquetípica de um gênero musical, e nesse corpo há um desvio, pois a letra da canção não se encaixa com os padrões recorrentes do estilo. Por outro, há um exemplo de oralidade, que por um desvio, não é falada, e sim cantada. Nos dois casos, a "máquina" (metáfora proposta por Bergson, conforme vimos anteriormente) tem as peças trocadas, alterando seu funcionamento.

De modo geral, todos os vídeos analisados apresentam, em sua intertextualidade, esse desvio da lógica da razão para a da imaginação, através de um jogo lúdico entre realidade e manipulação. Acreditamos, portanto, que para que uma música seja cômica, é interessante (não necessário) que se encaixe em um gênero específico. Dentre os vídeos remix mais populares que encontramos, a maioria propõe gêneros musicais bem demarcados, como rock, zumba, reagge e funk.

\subsection{Paródia e remix}

Já falamos sobre a recorrência da paródia no carnaval e na cultura remix. Autores como Sant'Anna (2000) e Hutcheon (1985) percebem na 
paródia uma consonância com a modernidade. Apesar de este não ser um fenômeno recente (a exemplo do carnaval na Idade Média e Renascimento), é um traço marcante de nossa época:

Talvez estejamos, então, a testemunhar hoje, na revivência das formas paródicas, a preparação de uma nova consciência linguística e literária, comparável ao papel que a paródia desempenhou, segundo Bakhtin, na sociedade medieval e renascentista (HUTCHEON, 1985, p. 91)

A paródia pode ser comparada com a metáfora: "ambas exigem que 0 decodificador construa um novo sentido através de interferências acerca de afirmações superficiais e complemente o primeiro plano com o conhecimento de um contexto de fundo" (HUTCHEON, 1985, p. 50). Tanto em uma quanto em outra, o leitor precisa reconhecer o código que foi apropriado, o que está do outro lado da janela de sentido que se abriu.

A ideia do reconhecimento do fragmento atualizado encontra eco em Navas (2012), que afirma que é possível reconhecer a historicidade do remix pelo reconhecimento de sua aura espetacular, conforme apontado no primeiro capítulo. Em uma paródia, assim como em um remix, abre-se uma janela através da qual se reconhece aquilo que foi modificado.

A aproximação da paródia com a metáfora também nos remete àquela entre metáfora e montagem, proposta por Carone (1974), citado subcapítulo 2.4. Ao modificar um original, podemos propor interferências e colisões com a inserção de novos elementos. Apesar dessas aproximações, quais seriam as diferenças entre remix e paródia? Seria todo remix parodístico?

Partamos para as definições. Buscando a etimologia da palavra, com apoio em Hutcheon (1985), descobrimos que "paródia" é a junção de "para" (oposição) com "odos" (canto). Essa junção de significados sugere uma espécie de contracanto, ou seja, um texto em contraste ou oposição a outro. Isso já nos sugere o reforço da ideia de diferença, ou seja, que ao repetir, é necessário marcar um distanciamento, necessário à associação entre dois códigos na mesma mensagem: um em presença (texto parodístico) e um em ausência (texto parodiado) (SANT'ANNA, 2000). A paródia "é uma confrontação estilística, uma recodificação moderna que estabelece a diferença no coração da semelhança" (HUTCHEON, 1985, p. 19).

Contudo, o prefixo "para" tem mais de um significado. Além de "oposição" também pode significar "ao longo de", ou "de acordo com". Quer 
dizer que há um paradoxo: a mesma expressão que sinaliza uma oposição sugere também uma continuidade. Isso também diz respeito à natureza da paródia, visto que apesar de marcar a diferença, é preciso manter o código original reconhecível.

O que a paródia faz é transpor um código de um contexto a outro. No contexto original, tal código possui aquele sentido que o leitor (decodificador) já conhece. Quando o contexto no qual esse código está inserido é outro, outras podem ser as leituras. "A paródia é, pois, na sua irônica 'transcontextualização' e inversão, repetição com diferença" (HUTCHEON, 1985). Encontramos, então, uma aproximação com a ideia de sampling, explorado no primeiro capítulo de acordo com Navas (2012).

Até aqui, temos a falsa impressão de que paródia e remix são sinônimos. Ocorre que o conceito de remix é mais amplo, pois abrange, além da paródia, outras formas de releitura nas quais o original não é modificado, como a citação e a alusão.

Hutcheon (1985) esclarece que para considerar um texto como parodístico, este precisa não apenas repetir algo conhecido, mas de certa forma distorcê-lo, de modo a propor outro discurso, sem apenas reafirmar o código a ser repetido. A mera repetição ou citação é denominada por Sant'Anna (2000) como paráfrase e por Hutcheon como pastiche (1985).

A principal estratégia de composição dos remix analisados é a manipulação vocal pela alteração do pitch e do tempo do áudio - o que, segundo Sant'Anna (2000), se aproxima mais do conceito de estilização, e não de paródia. Contudo, como vimos no subcapítulo 2.4, e como veremos de forma mais aprofundada no capítulo 3, existem remix que além dessa estratégia principal acrescentam outros fragmentos, de outras fontes, em associação ao vídeo que está sendo remixado. Nesses casos específicos, temos uma transposição de fragmentos entre diferentes contextos, que nem sempre fazem parte do mesmo universo temático que aquele, provocando alterações de significado. Nesses casos, podemos dizer que há a elaboração de paródia. 


\section{O CÔMICO A PARTIR DE COLISÕES}

Para iniciar este capítulo, nos provocamos novamente com a pergunta: o que pode tornar uma canção algo cômico? A seguir, nos aprofundaremos nessa questão, tentando abordá-la sob diversos pontos de vista, sem prendêla, ainda, ao nosso objeto. Vamos iniciar pensando especificamente na elaboração da letra, sem levar em conta os outros elementos (timbres, arranjos, etc).

Poderíamos ter uma letra que explorasse as características físicas do eu lírico (que chamaremos aqui de "personagem"), ou suas necessidades fisiológicas. O quanto está com fome, a forma como sente sono, ou como defecou nas próprias roupas. A letra também poderia revelar na personagem um comportamento considerado inadequado pela sociedade, como mentir de forma não convincente, errar cálculos simples ou explicar a definição de um termo que todos já conhecem, entre outras possibilidades grotescas ou insociáveis.

Percebemos que o trabalho de manipulação do áudio, nos remix analisados, propõe a formação de canções, como se tivessem sido escritos para tal, com estrofes e refrões. Portanto, nosso olhar sobre esses objetos foi no sentido de considerá-los canções, independente do contexto do vídeo, e de tentar entender como se deu o processo de transformação de uma fala em uma letra de canção.

Figura 13: Trecho do remix "Tô cagado de fome", do canal Timbu Fun

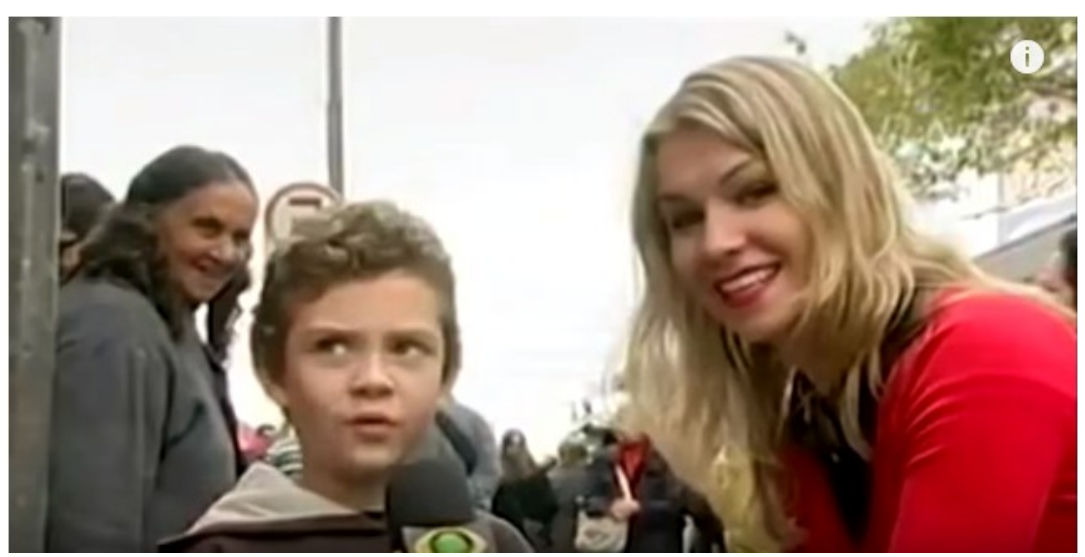

Fonte: https://www.youtube.com/user/Timbu Fun

Bons exemplos de canção grotesca, com letras voltada para o baixo corporal são os remix do viral "Tô cagado de fome". Em uma entrevista, um garotinho chamado José dispara essa frase para a repórter, que se põe a rir, desconcertada. O comportamento da personagem mostra que ainda não se ajustou às normas de conduta da sociedade, trazendo à tona não apenas uma 
sensação fisiológica (o que, para uma canção, já poderia ser potencialmente cômico), mas expressando-a com um termo considerado chulo. A seguir, transcrevemos um trecho do que o garoto diz, no original, entre as perguntas da repórter.

"Bom, eu vim pra passear, né? (...) Eu comprei o Goku ${ }^{32}$ Ontem e o Freeza hoje (...) Acabei de fazer uma, o Freeza, né? (...) Bom, eu já comi um lanche os anos passados, mas agora eu tô morrendo de fome e quero comer (...) É claro. Também, tô cagado de fome.

O canal Timbu Fun fez um remix ${ }^{33}$ no qual a canção possui apenas uma estrofe, além de outros momentos falados, e pequenas frases cantadas. A estrutura da letra é a seguinte:

Bom eu vim pra passear, né?

Bom eu vim pra passear, né?

Comprei o Goku ontem e o Freeza hoje

Comprei o Goku ontem e o Freeza hoje

A frase "tô cagado de fome", nesse remix, é falada e não cantada. Percebemos que os remixers não precisaram fazer grandes alterações ou recortes na ordem das frases para propor uma letra. Apenas repetições. A repetição, sendo um recurso comum tanto na música quanto na comédia ${ }^{34}$, encontra nesses remix uma articulação interessante. Normalmente, a música pede a repetição de versos - até porque o remixer não possui controle total do texto.

Os aplicativos possuem certos limites para que a voz continue soando natural. E mesmo que a intenção do remixer seja a de assumir o efeito metalizado que esses softwares provocam na voz, não há uma liberdade total para a composição de qualquer arranjo vocal sem que o resultado final soe fragmentado demais - e, baseados em nosso referencial teórico, principalmente em Bergson (1983), podemos afirmar que para que o efeito cômico seja atingido, é preciso haver um híbrido entre humano e máquina - ou seja, se a aparência de máquina se sobressair, perde-se a graça. Por isso, o áudio original acaba determinando alguns limites, tanto de tempo como de tom.

32 Goku e Freeza são brinquedos inspirados em personagens da série Dragon Ball Z. 33 Disponível em: https://www.youtube.com/watch?v=mR1ZEZCR5fw\&t=51s 34 Segundo Bergson (1983) 
Ainda assim, é possível fazer recortes e alterações na ordem da fala. Como exemplo, vejamos a letra de um remix ${ }^{35}$ baseado no mesmo original de "Tô cagado de fome", elaborado pelo canal Viradrop. Nesse caso, a letra é composta por duas estrofes:

Bom eu vim pra passear, né?

Comprei o Goku ontem e o Freeza hoje

Bom eu vim pra passear, né?

Comprei o Goku ontem e o Freeza hoje

Tô cagado de fome

Tô morrendo de fome

Tô cagado de fome

Tô morrendo de fome

Percebemos que no vídeo original as frases "tô cagado de fome" e "tô morrendo de fome" não estão juntas, o que indica que o remixer percebeu a possibilidade de uma elaboração em recortes, a partir da semelhança entre as frases, o que facilitaria a proposição de uma métrica.

O remix "Me caguei, moço", de Atilakw, como o próprio título sugere, também parte de uma situação centrada no baixo corporal. No original, a personagem (um menino) chora enquanto é filmada e explica que defecou nas próprias roupas. A letra do remix repete as frases "Eu me caguei na calça" e "Mas eu quero cagar".

Figura 14: Trecho do remix "Acertou, miserável", do canal Atilakw

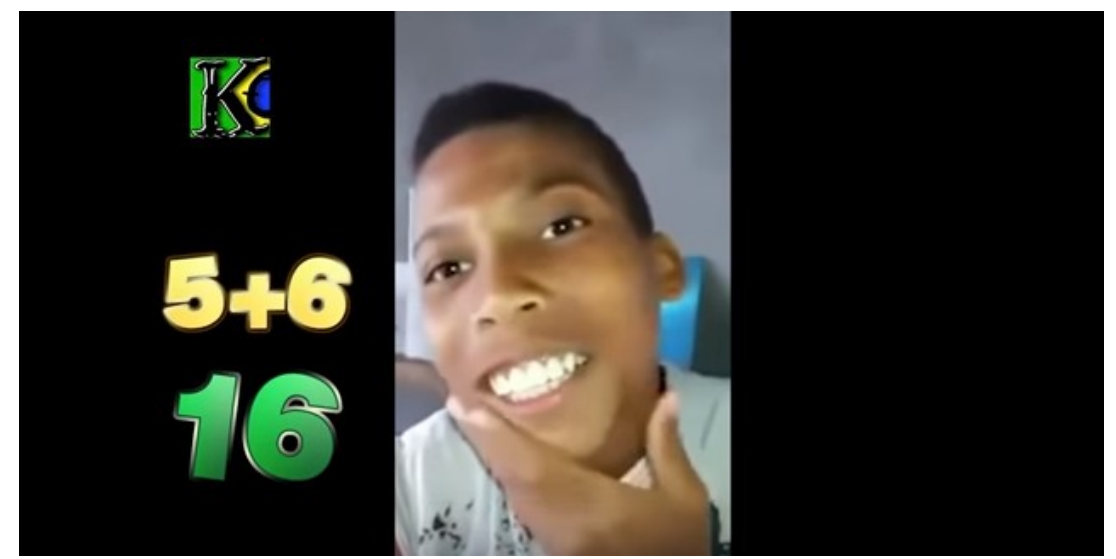

Fonte: https://www.youtube.com/watch?v=p7U6z7PdqwE\&t=29s

Outro exemplo de letra que demonstra um comportamento inadequado (no caso, o de não saber efetuar cálculos simples) é o remix de "acertou, miserável!". O remix não fez alterações na ordem do que foi dito no original. Executou apenas pequenos cortes. Um homem, fora do quadro, faz perguntas matemáticas para um garoto, que está sendo filmado. O garoto erra quase

35 Disponível em: https://www.youtube.com/watch?v=WWe6ZPo6z-4 
todas as contas. Contudo, o homem sempre afirma que ele acertou. Não é possível determinar, pela leitura do vídeo, se o homem estava sendo irônico ou se também não sabe realizar contas. A seguir, um trecho da letra. $O$ menino apenas canta os números que estão depois do sinal de "igual" (o restante é cantado pelo homem).

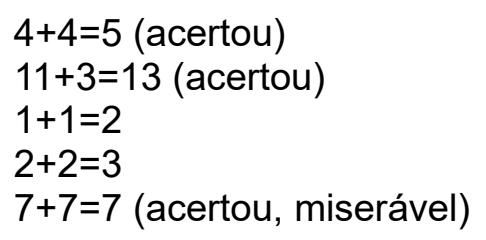

Os exemplos expostos nos ajudam a pensar, de modo superficial, em elementos que podem potencializar a comicidade de uma canção a partir da letra. Mas, para aprofundar a discussão, precisamos nos ater a outros elementos presentes em uma música.

Quanto à melodia, de acordo com as referências levantadas no capítulo 2, não podemos afirmar que possa ser cômica de forma isolada. Independente do gênero musical, nenhum arranjo sonoro fora de contexto e sem a voz humana poderia ser considerado cômico. Contudo, bastaria associar essa melodia a uma letra ou situação para se obter uma infinidade de possibilidades risíveis.

Se partíssemos de uma melodia conhecida, obteríamos efeitos cômicos inserindo-a em contextos inusitados - ou parodiando as letras. Se não for conhecida mas possa ser reconhecida como parte de um gênero musical, poderíamos provocar o riso associando-a a letras ou imagens que se oponham ao gênero. Por exemplo, uma macumba (ritmo africano) associada à imagem de um culto evangélico, em uma cultura na qual isso não seja comum.

Em um viral intitulado "guitarra humana kkkkkkk" um homem, aparentemente bêbado, se propõe a imitar uma guitarra com os sons da própria boca. Como bem coloca Bergson (1983), percebemos que nesse vídeo o humano é rebaixado à aparência de um objeto, o que nos parece divertido e indica que essa é a característica que torna o vídeo risível.

Tal vídeo foi remixado ${ }^{37}$ e nesse caso, não há letra. O canal Atilakw, então, propôs editar essa mídia fazendo a personagem executar as guitarras de músicas conhecidas, a saber: Sweet Child O'Mine (Guns and Roses), Enter Sandman (Metallica), Beat It (Michael Jackson), Californication (Red Hot Chilli 
Peppers) e Fear of the Dark (Iron Maiden), o que ressalta ainda mais a representação desse homem enquanto mero objeto (uma guitarra), sem perder a condição de humano (uma guitarra humana), ou seja, o mecânico calcado no vivo. Nesse caso, a guitarra não é um objeto qualquer, mas um instrumento musical de destaque.

Figura 15: Trecho do remix "Guitarra Humana", do canal Atilakw

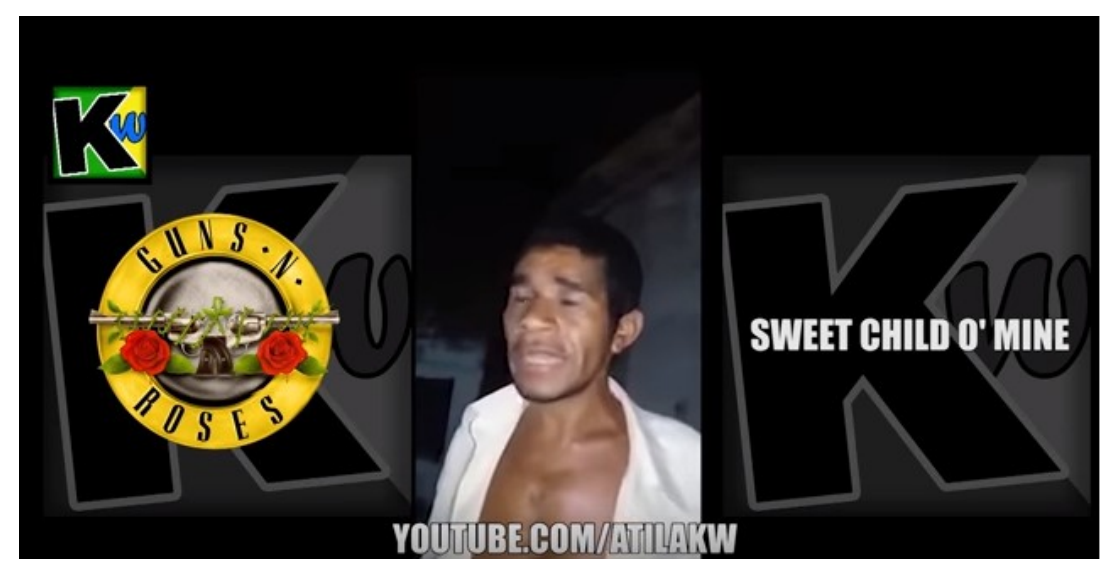

Fonte: https://www.youtube.com/watch?v=18hhUcqX3P8

Ressaltamos, também, a oposição entre os gêneros musicais escolhidos e o aparente contexto social da personagem. Interessante notar que, apesar de serem músicas originalmente dos gêneros pop e rock, o arranjo criado no remix propõe baterias e percussões inspiradas em ritmos brasileiros como o brega e o arrocha - estabelecendo, musicalmente, uma justaposição de estilos.

Nesse caso, consideramos a melodia cômica, mas não isoladamente. A comicidade está na novidade que o remix apresenta a melodias já conhecidas. Partiu-se de canções presentes no universo da cultura pop, dessacralizandoas, em uma atitude carnavalesca que as reconfigura em um contexto audiovisual inusitado.

Outro exemplo com pouco texto é o remix de "Choque da uva" ${ }^{38} \mathrm{O}$ vídeo original data do ano 2000, mas viralizou somente a partir de 2013, na plataforma YouTube. Em uma transmissão jornalística, o repórter, ao tocar em um cacho de uvas, sofre um choque elétrico, grita e cai, saindo do quadro. Ou seja, a principal ação da personagem (uma reação física) não possui texto verbal algum.

O canal Viradrop propôs um remix, ${ }^{39}$ no qual o momento principal é apenas a repetição em diversos tons musicais do gemido do repórter. A

38 Disponível em: https://www.youtube.com/watch?v=Ku61Yuw4Alk 39 Disponível em: https://www.youtube.com/watch?v=Ch6Csj7cytg 
melodia, por si só, nada tem de cômico. Mas, em se tratando de uma personagem humana, a repetição exaustiva de uma única ação acaba por atribuir a esse corpo um comportamento mecânico. O remix, de modo geral, é rico em imagens externas, extraídas de outras mídias, que dialogam com o original.

Aprofundemos nossa análise sobre possíveis aspectos cômicos presentes em uma canção. Consideremos, então, o ato de cantar, sem levar em consideração a letra nem a melodia. Ou seja, o canto enquanto ação. Primeiramente, suponhamos que uma ação parte de alguém - um ser humano. Digamos que não sabemos nada sobre essa personagem, mas podemos vê-la na tela. Poderíamos rir se de alguma forma o físico dessa pessoa se sobrepuser à canção. Por exemplo, se a pessoa soluça enquanto tenta cantar, se tem uma coceira incontrolável, se não tem uma voz apropriada para tal, ou se a sua aparência não condiz com o conteúdo da canção (por exemplo, uma pessoa cantar sobre honestidade enquanto pratica atos desonestos). Se há mais de uma personagem, também podemos pensar na relação ente elas, de modo a estabelecer oposições, sejam físicas, de caráter ou atitude.

Figura 16: Trecho do remix "Arrocha do Falsete", do canal Timbu Fun

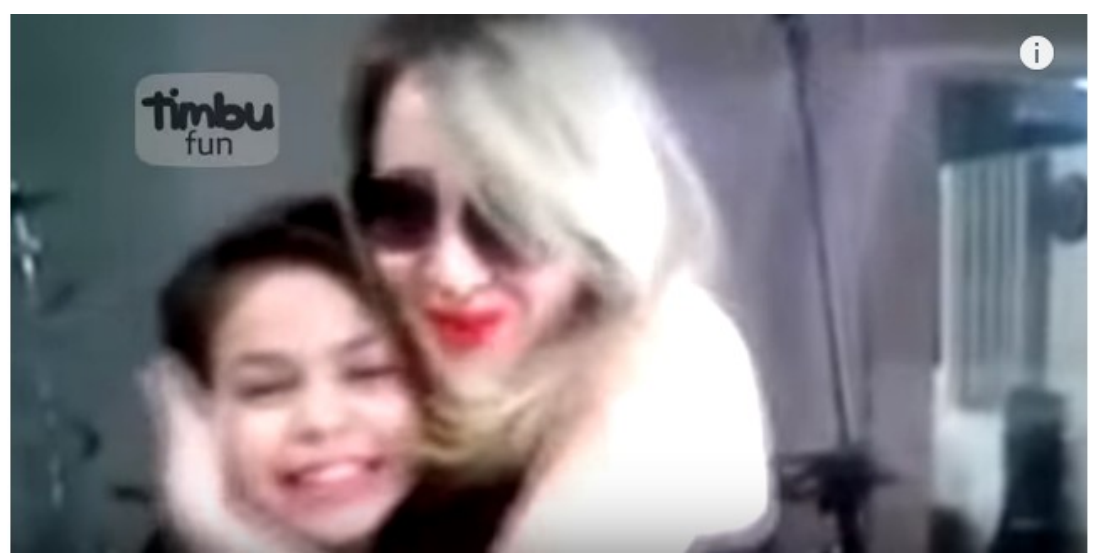

Fonte: https://www.youtube.com/watch?v=eYIO05fEz_k\&t=3s

Um exemplo de aspecto fisiológico que se sobressai à canção é o remix 40 "arrocha do falsete". No original, uma garotinha e uma mulher ensinam como cantar em falsete enquanto, na verdade, gritam. A voz estridente das duas ganha destaque, colocando em evidência uma característica física, ou seja, a própria voz. O vídeo foi remixado pelo canal Timbu Fun, que intercala os falsetes das duas ao som e imagem de uma panela de pressão (estabelecendo uma associação entre elas e o objeto) e de uma cabra gritando (outra relação, que consideramos grotesca pela presença do animal).

40 Disponível em: https://www.youtube.com/watch?v=eYIO05fEz_k\&t=3s 
É oportuno citar também o remix $x^{41}$ "Esse programa aqui tá uma poha", do Canal Viradrop. A personagem principal, entrevistada no programa de televisão "Esporte Cidade"22", reclama que o programa está ruim porque não estão o deixando falar. Por um momento, enquanto fala, visivelmente nervoso, movimenta o microfone de lapela que está preso à gola de sua camisa. $\mathrm{O}$ remixer selecionou esse trecho e o pôs em repetições sequenciais (looping), de modo que esse movimento pareceu se tornar uma espécie de tique nervoso que o homem tem enquanto canta - o que desloca nossa atenção do conteúdo da letra para o físico da personagem. O movimento, colocado em repetição, faz com que a ele seja levado ao ridículo, na medida em que sua ação física se torna incongruente.

Figura 17: Trecho do remix "Esse programa aqui tá uma poha", do canal Viradrop

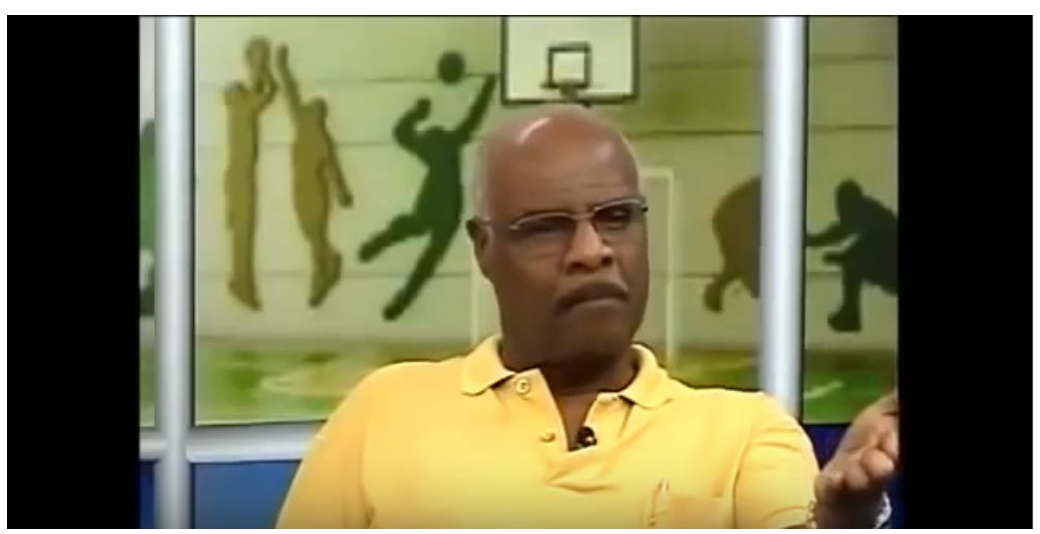

Fonte: https://www.youtube.com/watch?v=EwNbfelhrkk\&t=107s

Outro exemplo de ação física que se sobressai ao contexto do vídeo pode ser visto no remix ${ }^{43}$ "Senhora", que citamos no capítulo 2. A personagem tenta "abandonar" a canção ao correr, mas continua presente no vídeo, já que a câmera a segue. Então, a canção, cuja letra é "senhora", é cantada pela repórter, enquanto corre - o que, além de ser uma ação física, é incongruente com o que se espera do contexto (uma transmissão jornalística).

Analisemos, agora, outro aspecto, nos aprofundando ainda no ato de cantar. E se considerássemos o canto enquanto mera ação, mas sem levar em conta as características da personagem? Podemos pensar em situações (conforme exemplificaremos a seguir) nas quais o canto não caiba, de modo que cantar possa ser considerado um ato incoerente ou inadequado, levando em conta as características externas à personagem. Considerando os meios audiovisuais, o ato de cantar costuma estar circunscrito a determinados

41 Disponível em: https://www.youtube.com/watch?v=EwNbfelhrkk\&t=107s

42 Transmitido pela Rede Cidade, emissora regional do Ceará.

43 Disponível em: https://www.youtube.com/watch?v=V-JqxBmEL_g 
espaços e formatos, como filmagens de shows, videoclipes, filmes musicais, documentários, etc. Imaginemos, então, um canto que surja em meio a um noticiário, transmissão de discurso, velório, votação ou outros contextos cerimoniais.

O conceito de carnavalização, explorado por Bakhtin (2008), nos ajuda a perceber diversos remix que rompem com a cerimonialidade dos originais pela simples inserção de músicas. Basta inserir uma melodia para dessacralizar instituições de poder.

Durante o mandato da presidenta Dilma Roussef, o canal Timbu Fun realizou muitos remix que a homenageavam, ao mesmo tempo em que a ridicularizavam. Os vídeos originais normalmente ocorriam em situações cerimoniosas, pronunciamentos e discursos, o que possibilita que o simples ato de cantar se torne algo divertido.

A partir da análise dos diversos aspectos presentes em uma canção (letra, melodia, personagens, situação), vemos que, em uma montagem audiovisual com finalidade cômica, é possível formular vários tipos de colisão. Entre o original e o remix, percebemos que a personagem se tornou uma espécie de brinquedo. Seus atos são desprovidos de autonomia. Nos divertimos observando e ouvindo como foi manipulada de acordo com a vontade do(a) remixer. Mas ainda enxergamos, ali, traços do humano. A edição não foi suficiente para que não reconheçamos os comportamentos humanos em sua fluidez, tal como estamos acostumados a observar nas mídias digitais em meio a uma lista infindável de links, e com uma estética de edição e montagem que já está impregnada em nossa cultura e imaginário audiovisuais.

Entre o original e o remix, há, no mínimo, a inserção de dois novos elementos: uma nova ação (a de cantar), a ser sobreposta às ações da personagem, e uma melodia. Desse modo, a personagem se torna um fantoche, uma marionete.

Quase sempre ignoramos o que há de infantil ainda, por assim dizer, na maioria dos nossos sentimentos alegres. No entanto, quantos prazeres atuais não passariam de lembranças de prazeres passados, se os examinássemos de perto! Que restaria de muitos de nossos sentimentos se os relacionássemos ao que têm de estritamente vívido, se lhes retirássemos tudo o que é simplesmente rememorado? Quem sabe mesmo se não nos tornamos impermeáveis, a partir de certa idade, à alegria viçosa e nova, e se as mais doces satisfações do homem maduro podem ser coisa diferente de sentimentos de infância revivificados, brisa perfumada que um passado cada vez mais distante nos envia por bafejos cada vez 
mais raros? Seja qual for a resposta a essa questão muito geral, um ponto fica fora de dúvida: não pode haver ruptura entre o prazer de brincar, na criança, e o mesmo prazer, no adulto (BERGSON, 1983, p. 35).

A aproximação do riso com a brincadeira, proposta por Bergson, nos parece pertinente para a análise de nosso objeto. Há, no ato do remixer, não apenas técnicas de justaposições de elementos, mas também uma pulsão irreverente, um olhar carnavalizante.

Apenas esse movimento de sobreposição de ações provoca uma ironia entre a ação que a personagem intenciona e a que executa (pois agora, além de tudo, canta). Ela parece ser enganada, pois não sabe que está cantando, e ninguém a avisou disso. Nós, espectadores, sabemos que aquele ato específico, ou seja, a ação de cantar, não existia - o que nos aproxima do papel de cúmplices, como crianças que observam alguém cair em uma armadilha.

Em nossa análise percebemos que, de modo geral, o audiovisual de acontecimento tem como mote a ação da personagem principal. Todos os vídeos analisados carregam essa característica em comum: os vídeos originais viralizaram pelo conteúdo cômico das ações (acontecimentos) ali executadas; e os remix pela sobreposição de ações - não apenas da ação de cantar, da personagem principal, mas, em alguns casos, outras ações provocadas pela inserção de outros elementos.

Essas ações, executadas pelas personagens principais (presentes nos originais) podem ser conscientes ou não: explicar o significado de uma palavra, gritar, se confundir, prestar um depoimento, etc. São ações humanas, que na mídia gravada se revelam cômicas e que são editadas de modo a acrescentar de modo cumulativo outra ação: a de cantar.

Como vimos, as ações das personagens, nos vídeos originais, são, por vezes, antissociais, grotescas ou inadequadas. A tecnologia oferece, então, suporte para criar ainda mais incongruência à ação.

Analisamos um total de 120 remix, que partiram de 102 virais, publicados até julho de 2018, na tentativa de identificar aspectos em comum que nos ajudem a compreender a maneira como o cômico é construído nesses trabalhos. A seguir, listamos todos eles. Mas deixamos claro que o objetivo não foi descrever um a um, e sim investigar características gerais. 
Tabela 1: Relação dos remix analisados

\begin{tabular}{|c|c|}
\hline REMIX & CANAL \\
\hline Acertou Miserável & Atillakw \\
\hline Adorável & Timbu Fun \\
\hline Ai pai, para! & Atillakw \\
\hline Alborghetti & Viradrop \\
\hline Ar Condicionado & Timbu Fun \\
\hline Arrocha do falsete & Timbu Fun \\
\hline AtilaKw no programa Pânico & Atillakw \\
\hline Baby do Biruleibe & Atillakw \\
\hline Bambam Bodybuilder & Atillakw \\
\hline Bambam Enlouquecendo & Viradrop \\
\hline Bigodinho fininho & Atillakw \\
\hline Bilada & Viradrop \\
\hline Cadê todo mundo? & Atillakw \\
\hline Casa do Jubileu & Atillakw \\
\hline Cepo de madeira & Atillakw \\
\hline Cepo de Madeira & Timbu Fun \\
\hline Cepo de Madeira & Viradrop \\
\hline Chama a mamãe, ketlyn & Atillakw \\
\hline Choque da Uva & Viradrop \\
\hline Claudinho, amor da minha vida & Atillakw \\
\hline Coé Rapaziada & Viradrop \\
\hline Comi seu batom & Atillakw \\
\hline Como você é burro & Viradrop \\
\hline Compilado 50k & Viradrop \\
\hline Corsinha amarelo & Atillakw \\
\hline Cortando a placa de $100 \mathrm{k}$ & Viradrop \\
\hline Delato? & Timbu Fun \\
\hline Dilma - A meta & Timbu Fun \\
\hline Dilma - Mosquita & Timbu Fun \\
\hline Diz Aécio & Timbu Fun \\
\hline Dublador do Sid (é desse jeito) & Atillakw \\
\hline É pra rapariga & Atillakw \\
\hline Ele pegou minha voz & Atillakw \\
\hline Empolgante (bem loco) & Viradrop \\
\hline Errou & Viradrop \\
\hline Esse programa aqui tá uma poha & Viradrop \\
\hline Estocando o vento & Timbu Fun \\
\hline Eu fiz vestibular & Atillakw \\
\hline Eu fui feito pra comer & Atillakw \\
\hline Eu sou o Dougras & Atillakw \\
\hline
\end{tabular}




\begin{tabular}{|c|c|}
\hline Eu sou o Dougras & Viradrop \\
\hline Eu sou um merda & Atillakw \\
\hline Eu to morrendo & Atillakw \\
\hline Everson Zoio & Viradrop \\
\hline Fã do raça negra & Atillakw \\
\hline Faz o urro & Viradrop \\
\hline Felipe Smith & Atillakw \\
\hline Galo cego & Atillakw \\
\hline Galo cego & Viradrop \\
\hline Gigabigulé & Viradrop \\
\hline Guitarra humana & Atillakw \\
\hline Guitarra Humana & Timbu Fun \\
\hline Guitarra humana (clássica) & Timbu Fun \\
\hline Higor Nera gay? & Atillakw \\
\hline Irineu & Atillakw \\
\hline Irineu & Viradrop \\
\hline Isso é ser fraco & Timbu Fun \\
\hline Já acabou Jéssica & Viradrop \\
\hline Já deu por hoje & Viradrop \\
\hline Klein? Tales? Sales? & Timbu Fun \\
\hline Legal bem loco empolgante & Timbu Fun \\
\hline Magrelinho & Atillakw \\
\hline Me caguei, moço & Atillakw \\
\hline Me estruparam & Atillakw \\
\hline Michel dos teclados (zoeira) & Timbu Fun \\
\hline Minha querida & Atillakw \\
\hline Morre diabo & Atillakw \\
\hline Morri & Viradrop \\
\hline Mulheres & Timbu Fun \\
\hline Não Sei & Viradrop \\
\hline Não tem cerol, não & Atillakw \\
\hline No céu tem pão? & Atillakw \\
\hline No céu tem pão? & Viradrop \\
\hline Noel filho da puta & Atillakw \\
\hline Nossa! (milena enen) & Viradrop \\
\hline Nunca nem vi & Atillakw \\
\hline Ô Papa Capim & Timbu Fun \\
\hline O que você lanchou? & Timbu Fun \\
\hline O Sangue de Jesus tem poder & Atillakw \\
\hline Olá Marilene & Viradrop \\
\hline Olha eu com boné & Viradrop \\
\hline OOEEEE (Dorinho kum) & Viradrop \\
\hline Pai de família & Viradrop \\
\hline
\end{tabular}




\begin{tabular}{|c|c|}
\hline Panificadora alfa & Atillakw \\
\hline Papa-capim dos meus sonhos & Atillakw \\
\hline Pesadão & Viradrop \\
\hline Quero café & Atillakw \\
\hline Quero Café & Timbu Fun \\
\hline Quero café & Viradrop \\
\hline Quero Café extended & Viradrop \\
\hline Quero homem não, quero comida & Atillakw \\
\hline Sabia não que merda hein & Atillakw \\
\hline Sai, satanás & Atillakw \\
\hline Samba do Grand Canyon & Timbu Fun \\
\hline Sargento Fahur & Viradrop \\
\hline Saudação à mandioca & Timbu Fun \\
\hline Sé Loco Cachuera & Viradrop \\
\hline Senhora & Timbu Fun \\
\hline Serjão Berranteiro & Atillakw \\
\hline Serjão Berranteiro matador de onça & Viradrop \\
\hline Serumaninho & Atillakw \\
\hline Seu buceta & Viradrop \\
\hline Sou faraó & Viradrop \\
\hline Suco de maracujá & Atillakw \\
\hline Tá me tirando? & Atillakw \\
\hline The Last of Us & Viradrop \\
\hline To cagado de fome & Viradrop \\
\hline Tô cagado de fome & Timbu Fun \\
\hline Top & Viradrop \\
\hline Tu é louca & Atillakw \\
\hline Unpacking placa de 1 milhão & Atillakw \\
\hline Vasco campeão do mundo & Atillakw \\
\hline Vestido escrito ku & Atillakw \\
\hline Viraresponde 1 & Viradrop \\
\hline Vocês vão ter que me engolir & Timbu Fun \\
\hline Volta, querida & Timbu Fun \\
\hline Walter o cachorro cantor & Timbu Fun \\
\hline Work Alcoolic & Timbu Fun \\
\hline Baguncinha & Atillakw \\
\hline
\end{tabular}

Apesar de nosso enfoque de pesquisa ter sido sobre vídeos remix com alteração de tom e tempo da voz e elaboração musical, boa parte dos analisados não se centra somente nesse formato, trabalhando também com a inserção de elementos visuais extraídos de outros vídeos (em alguns casos, filmados especificamente para o trabalho). 
A inserção pode partir de qualquer outro material audiovisual, conhecido ou não: vídeos caseiros, trechos de filmes, telejornais, jogos eletrônicos, etc. Portanto, analisaremos não somente as características ligadas à alteração da voz e à inserção da melodia, mas também levaremos em consideração outras inserções.

Por um lado, os vídeos originais fornecem uma série de elementos: personagens, palavras, ações, imagens, emoções. Por outro, os remixers podem fornecer, além de músicas, efeitos visuais, proposições narrativas, legendas, outros personagens, etc. São blocos de significação que colidem, estabelecendo, entre si, os seguintes tipos de relação:

- $\quad$ incongruências;

- coincidências;

- hipérboles.

Incongruências seriam bissociações (sonoras, visuais e linguísticas) sem sentido ou em oposição ao original. Coincidências ocorrem na justaposição entre blocos de significação independentes que possuem algum aspecto em comum. E, como vimos no capítulo anterior, a hipérbole ocorre por exagero. De modo geral, essas relações ocorrem a partir - ou entre - os seguintes elementos:

- $\quad$ estados de espírito;

- textos verbais;

- ações;

- $\quad$ personagens;

- arranjos sonoros;

- causa e efeito.

A seguir, analisaremos diversos tipos de colisão envolvendo essas categorias, e também alguns desdobramentos. ${ }^{44}$

\subsection{Entre estado de espírito da personagem e arranjo sonoro}

Este tipo de relação é comum a todos os remix - mesmo os que não inserem nenhum material visual externo. A escolha do gênero musical é algo que diz respeito não somente à preferência do remixer, mas às suas limitações. Os remix do canal Viradrop são elaborados por um DJ, portanto, todos os arranjos são de timbres eletrônicos. O trabalho do canal Timbu Fun é feito por 
uma equipe, em estúdio e com diversos instrumentos, o que se reflete no trabalho, que possui uma ampla diversidade de estilos. Já em Atilakw, há uma mistura de acordes eletrônicos com instrumentos gravados em estúdio. É partindo dessas possibilidades preexistentes que os remixers podem fazer suas primeiras escolhas.

Elege-se, então, um vídeo original que tem como mote a ação de alguma personagem, que gera um acontecimento. Essa ação traz consigo uma emoção, que pode ser de raiva, deboche, admiração, etc. Como visto no capítulo 2, é comum que, por uma questão cultural, certos gêneros musicais sejam associados a determinados estados de espírito. Por exemplo, a raiva estar associada a um estilo do heavy metal, até mesmo por um estilo de vocal agressivo ("gritado", em alguns casos). Mas percebamos que esse exemplo não poderia ser executado por um remixer que não dispusesse de aparato técnico musical para produzir uma música de rock.

Outro ponto a se chamar atenção é que a leitura que fazemos do estado de espírito da personagem pode ser alterada pela forma como o remixer manipula a voz. Para ilustrar essa possibilidade, citemos o remix "Sou Faraó". No original, um garotinho, com o rosto inserido na imagem da esfinge (por um efeito especial), canta um rap cuja letra descreve o egito antigo. 0 garoto, no original, não parece sentir raiva. Apenas executa a ação que se propôs.

Figura 18: Trecho do remix "Sou Faraó", do canal Viradrop

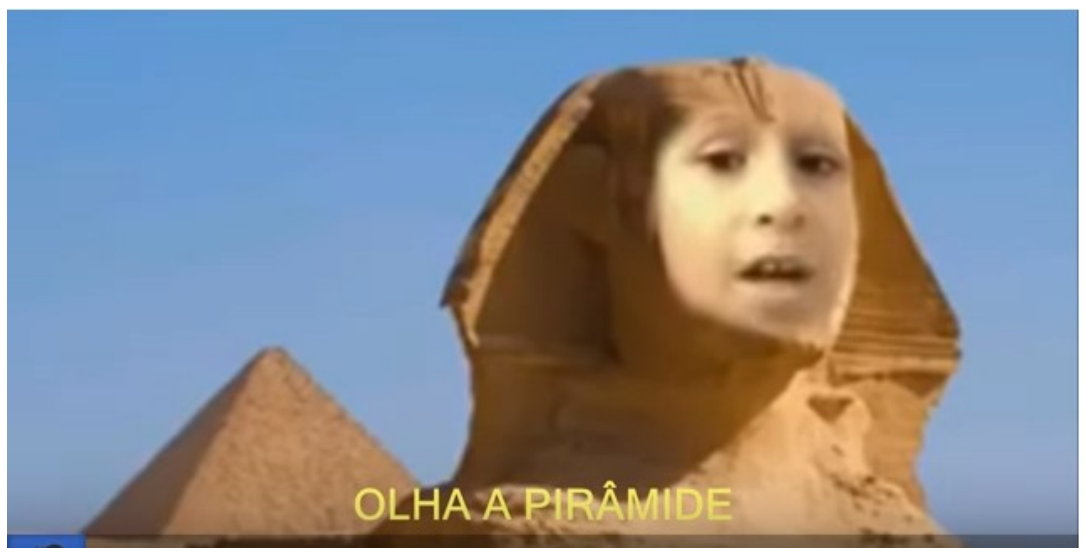

Fonte: https://www.youtube.com/watch?v=n0-HLCrRGHo

No remix ${ }^{45}$ do canal Viradrop, que propõe uma música eletrônica, o tom de voz do menino se tornou algo "ameaçador". Essa mudança de estado de espírito induzida tem potencial cômico, pois é mais uma forma de manipular a

45 Disponível em: https://www.youtube.com/watch?v=n0-HLCrRGHo 
personagem, extraindo sua autonomia. No remix ${ }^{46}$ "estocando o vento", do canal Timbu Fun, a ex-presidenta Dilma Roussef parece não fazer um pronunciamento, e sim dar uma aula de zumba. Voltaremos a falar desse vídeo posteriormente.

Há também a opção de trabalhar com acordes que tornem a canção "leve", "alegre", com timbres mais agudos e ritmos abrasileirados, como é a opção mais recorrente dos canais Timbu Fun e Atillakw. Essas escolhas nos chamam a atenção, pois parecem oscilar entre a coincidência e a incongruência.

Nesse caso, coincidências ocorrem quando a música parece embalar o estado de espírito da personagem ou do espectador em relação com a personagem. Por exemplo, no remix ${ }^{47}$ "eu comi seu batom”, cuja personagem principal é uma criança muito jovem (quase uma bebê), é colocado no arranjo um teclado com notas agudas, características de músicas feitas para bebês.

Figura 19: Trecho do remix "Eu comi seu batom", do canal Atilakw

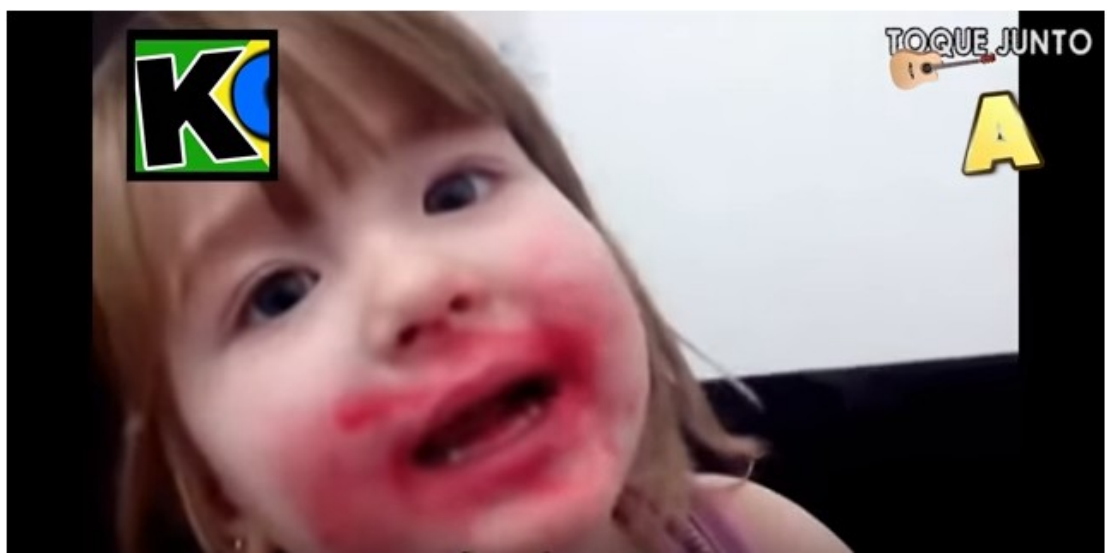

Fonte: $\mathrm{https}: / / \mathrm{www}$.youtube.com/watch?v=dhwsJxV4hs4\&t=42s

Escolhas incongruentes seriam aquelas nas quais não acontece um encaixe semântico. Um exemplo nos ajudará a compreender melhor a dicotomia entre coincidência e incongruência: façamos um comparativo a partir do original "Quero Café". Um senhor invade a gravação de uma entrevista para gritar que quer café. O estado de espírito que podemos ler dessa personagem é de raiva, revolta, indignação, fúria. Foi remixado pelos três canais.

O canal Timbu Fun trabalhou com um heavy metal, ou seja, uma escolha ${ }^{48}$ culturalmente coerente com a emoção da personagem (coincidência).

46 Disponível em: https://www.youtube.com/watch?v=dhwsJxV4hs4\&t=70s 47 Disponivel em: https://www.youtube.com/watch?v=dhwsJxV4hs4\&t=42s 48 Disponível em: https://www.youtube.com/watch?v=XO_Rj7hmvFc 
Já Atillakw fez uma escolha ${ }^{49}$ incongruente: um arranjo que se aproxima de um axé, ou uma marchinha de carnaval. A relação entre a emoção e o arranjo sonoro, nesse caso, não faz sentido, provocando uma colisão de potencial cômico. A proposta do canal Viradrop ${ }^{50}$ fica no meio termo, pois em alguns trechos soa mais "séria" e em outros assume tom alegre, dançante.

Nossa proposta não é apontar qual tipo de relação (coincidência ou incongruência) seria mais eficiente para provocar o riso, pois percebemos que cada um dos três remix possui uma comicidade própria. Além disso, mesmo bissociações coincidentes são fundadas em uma incongruência colocada desde o início: o ato de cantar.

Figura 20: Trecho do remix "Quero café", do canal Viradrop

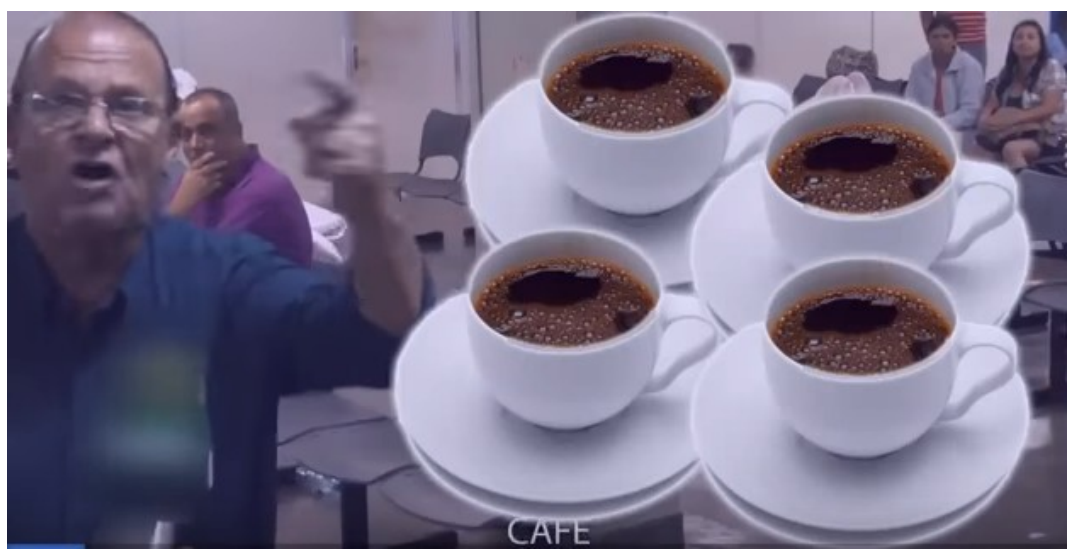

Fonte: https://www.youtube.com/watch?v=jm8KzK0Yr6I

Essa oscilação entre coincidência e incongruência pode possuir, no mesmo remix, várias nuances. Por exemplo, o remix "Bambam Bodybuilder", de AtillaKw $w^{51}$, parte de um original no qual o ex-BBB ${ }^{52}$ Bambam faz demonstrações de força muscular em uma academia, enquanto grita, como se estivesse em um estado de espírito de fúria e orgulho. O canal optou por acordes de heavy metal, uma escolha coincidente com a emoção da personagem. Contudo, há um trecho da música em que o arranjo vocal atinge uma nota muito mais aguda que as demais, como que indicando um "ato falho" feminino ou delicado - estabelecendo um paradoxo entre a emoção original e o seu contrário, a fragilidade - lembrando que a associação de feminino à fragilidade é cultural, o que também indica uma possível opinião do remixer acerca desse tipo de comportamento.

49 Disponível em: https://www.youtube.com/watch?v=xc0zrMmbjLw 50 Disponível em: https://www.youtube.com/watch?v=jm8KzKOYr6I 51 Disponível em: https://www.youtube.com/watch?v=vfCozg8Yhxk 52 Vencedor do programa Big Brother Brasil, veiculado pela Rede Globo em 200X. 
De modo geral, podemos perceber que a criação do arranjo sonoro, além de modificar nossa leitura sobre a personagem, pode "ir na mesma direção" do original, estabelecendo um vetor paralelo, ou pode inaugurar um vetor oposto - o que influencia na leitura que fazemos da obra.

\subsection{Entre causa e efeito}

Continuaremos analisando paralelismos e oposições, mas pensando em outros elementos. Neste subcapítulo refletiremos sobre alguns remix que, de alguma forma, alteraram a linha narrativa do original. Em geral, para uma ação contida no vídeo original, é inserida artificialmente uma consequência inesperada.

São casos em que se trabalha com um elemento surpresa, de modo que a "colisão" ocorra antes que o espectador possa prevê-la. Essa surpresa geralmente ocorre em chave hiperbólica. Como falamos no segundo capítulo, a hipérbole pode acontecer tanto pelo exagero para mais (aumentativa) quanto para menos (diminutiva).

Figura 21: Trecho do remix "Bambam enlouquecendo", do canal Viradrop

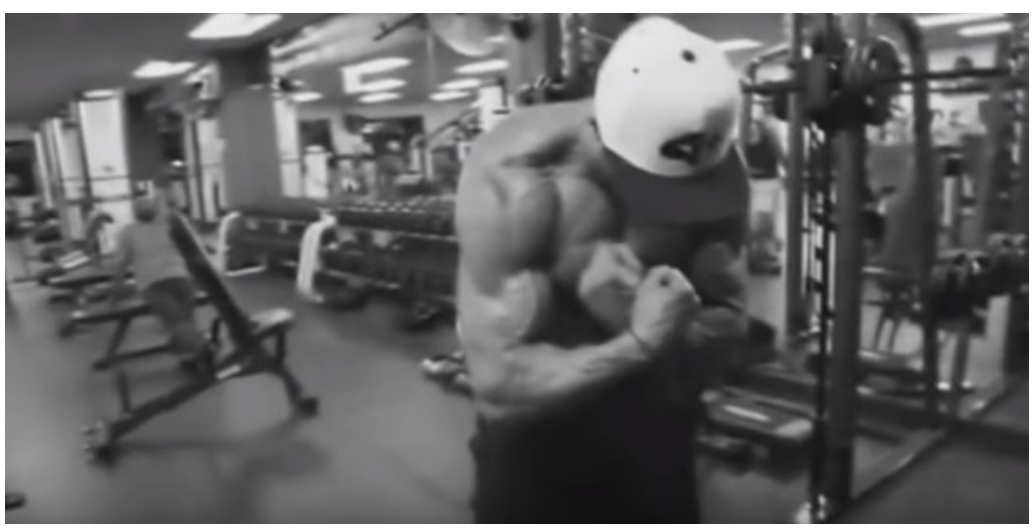

Fonte: https://www.youtube.com/watch?v=leXDXGkpBQY

Já falamos sobre o viral do ex-BBB Bambam. Esse mesmo original recebeu outro remix ${ }^{53}$, pelo canal Viradrop, em que no final do vídeo, depois que a música termina, a personagem faz um grande esforço para contrair seus músculos, em silêncio, até que ouvimos um ruído de flatulência. Nesse caso, o efeito, em relação à causa, surpreende por ser uma hipérbole de exagero diminutivo, que desemboca em acontecimento de menor "importância" que o anterior, até mesmo por vir do baixo corporal. Esse efeito põe a personagem em situação vexatória, não correspondente ao status da força física, em uma 
ação não aceita socialmente. Há uma certa coincidência entre causa e efeito, pois a relação entre gases e esforço físico, no corpo humano, é natural.

Como exemplo de hipérbole aumentativa, nessa relação entre causa e efeito, citamos o remix ${ }^{54}$ de "Cepo de Madeira" do canal Viradrop, cujo original já foi comentado na abertura do primeiro capítulo. Ao final do vídeo, Gugu Gaiteiro se prepara, mais uma vez, para atingir o prego com o martelo. O remixer insere esse trecho novamente em silêncio, após o final da música, criando um suspense. Ao atingir o prego, em vez de um simples estouro, o quadro inteiro é tomado por uma grande explosão.

Figura 22: Trecho do remix "Coé rapaziada", do canal Viradrop

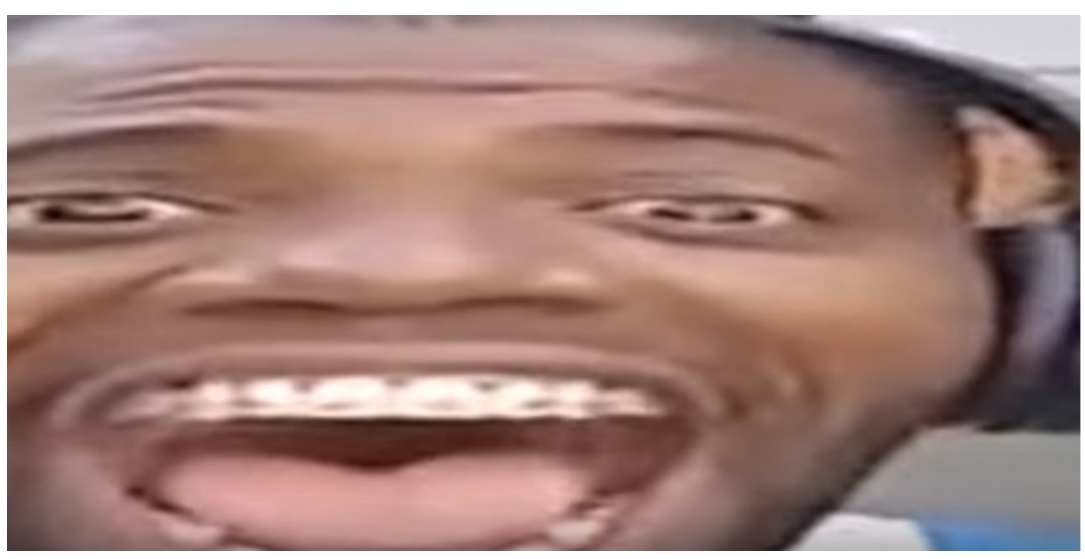

Fonte: https://www.youtube.com/watch?v=qEuT5JKofeA

Outro exemplo de surpresa está também no canal Viradrop. Trata-se do remix ${ }^{55}$ de "Coé Rapaziada", cujo original consiste simplesmente em um rapaz, em um ponto de ônibus, que acena positivamente para a câmera, como quem cumprimenta amigos, falando "coé rapaziada" aos gritos comportamento inadequado para nossos padrões sociais. Ao final do remix, após os créditos, por apenas um segundo vemos novamente o rosto do rapaz, tomando a tela inteira, o que torna sua aparência assustadora - se contrapondo ao estado de espírito original.

De modo geral, o canal Viradrop é o que mais propõe distorções semânticas em seus remix, estabelecendo arranjos inusitados entre as ações dos personagens principais e consequências inseridas artificialmente, sem que seja necessária a introdução de uma nova personagem. No remix "Choque da uva", já mencionado aqui, é exibida a legenda "e morreu", logo após o repórter sofrer o choque e cair.

54 Disponível em: https://www.youtube.com/watch?v=SBJFFHm8R4g\&t=3s 55 Disponível em: https://www.youtube.com/watch?v=qEuT5JKofeA 
Figura 23: Trecho do remix "Choque da uva", do canal Viradrop

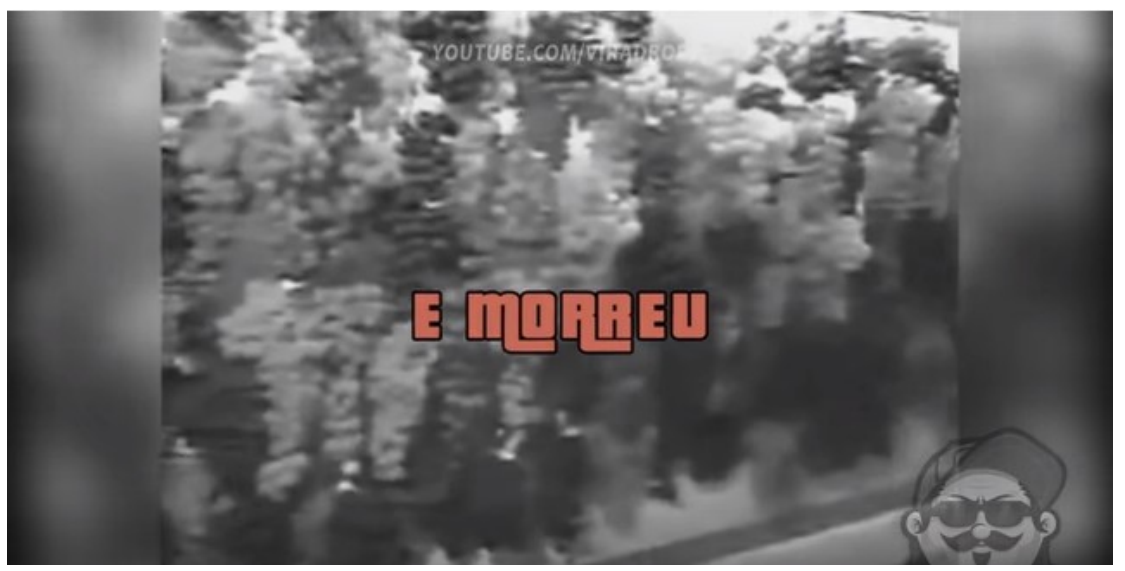

Fonte: https://www.youtube.com/channel/UCCjJ6nzg3-74FbISqmE_EcA

Até aqui, analisamos brevemente os arranjos entre causa e efeito, provocados pela inserção de elementos externos aos vídeos originais, mas sem considerar, ainda, a inserção de outros personagens - característica recorrente em remix dos três canais. A seguir, veremos outros tipos de colisão nos quais isso pode ocorrer.

\subsection{Por coincidência a partir de texto verbal ou ação}

Analisemos outro tipo de coincidência provocada nos remix: a que é produzida tomando como referência a fala ou ação de uma personagem. Em alguns casos, a inserção de uma nova personagem ocorre para ampliar o significado de algo que é dito pela personagem principal, indicando um desenvolvimento temático. Por exemplo, no remix de "Isso é ser fraco", do canal Timbu Fun, um garotinho, entrevistado na sala de aula, discorre sobre o que é a fraqueza, sob seu ponto de vista. No original, o menino surpreende pela eloquência de sua fala, revelando uma maturidade incomum para uma criança. O conteúdo de sua fala é bastante moralizante, e o remix inclui trechos de transmissões de discussões entre políticos, estabelecendo uma coincidência entre o que ele diz e as imagens justapostas.

O mesmo canal elaborou o remix ${ }^{56 " O}$ que você lanchou?", no qual um menino obeso descreve que lanchou um sanduíche. Há outro viral que tem a palavra sanduiche como mote: em 2005, uma nutricionista chamada Ruth Lemos, em entrevista ao jornal "Bom Dia PE", se atrapalhou errando a pronúncia das palavras por um problema técnico de delay no fone de ouvido, repetindo o final de palavras como em "sanduiche-iche", expressão que a tornou conhecida.

56 Disponível em: https://www.youtube.com/watch?v=AJQ5AV-5sK8 
O remix, então, associou o viral de Ruth Lemos ao do garotinho. Quando ele mastiga, adiciona-se um dueto, com arranjo vocal entre os dois personagens. A montagem promove uma situação de paralelismo com os dois cantando juntos a palavra "sanduíche", em diferentes tons, formando uma harmonia. A inserção dessa personagem secundária ocorre rapidamente, como uma surpresa para o espectador.

Figura 24: Trecho do remix "O que você lanchou?", do canal Timbu Fun

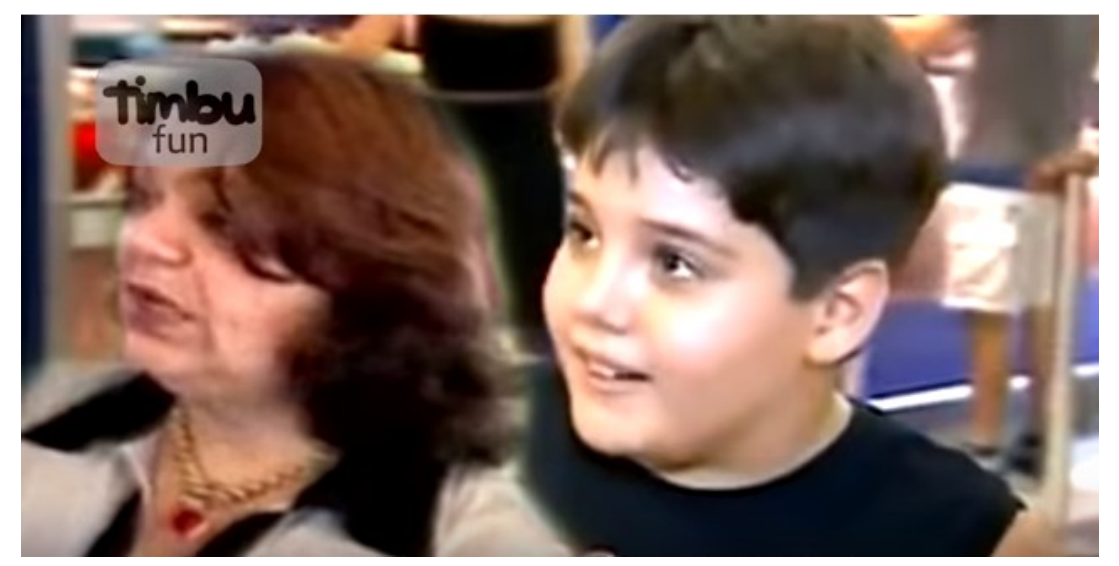

Fonte: https://www.youtube.com/watch?v=AJQ5AV-5sK8

O remix ${ }^{57 “ T o p ”, ~ e l a b o r a d o ~ p e l o ~ c a n a l ~ V i r a d r o p, ~ p a r t e ~ d e ~ u m ~ o r i g i n a l ~ n o ~}$ qual uma garota discorre, para a câmera, sobre a definição da gíria "top", como se estivesse dando uma espécie de aula. Ela afirma que um exemplo do uso dessa palavra seria na frase "A Angelina Jolie estava 'top' na confraternização dos Power Rangers". Provavelmente essa frase foi um dos motivos de o vídeo ter viralizado, pois o exemplo aponta uma situação nada banal, bastante específica e inusitada. O remixer, então, optou por concretizar o exemplo, inserindo cenas da série "Power Rangers", exibida em diversos canais de televisão desde os anos 1990. Esse é outro caso em que a coincidência foi favorável ao cômico, levando "ao pé da letra" (o que é absurdo) o exemplo elaborado pela moça.

A alusão aos Power Rangers ganha desenvolvimento em um momento que é exibido um vídeo com várias pessoas, vestidas como os heróis da série, dançando - o que já é, em si, um remix. Essa mídia materializa o que poderia ser uma confraternização dos Power Rangers, gerando uma coincidência entre dois blocos de significação independentes.

Existem diversos outros exemplos de expressões tomadas em sentido literal. Por exemplo, no remix ${ }^{58}$ "Pesadão" - cujo original se trata de um rapaz 57 Disponível em: https://www.youtube.com/watch?v=_SKG6edH3IM 58 Disponível em: https://www.youtube.com/watch?v=sQXvbpLVxZc 
que fala tal palavra como um bordão pessoal, o canal Viradrop justapõe a essa fala à imagem de um rapaz gordo que cai sobre uma bola, esmagando-a.

Há também outros exemplos de inserção de personagens a partir de fala ou ação. Em alguns casos, a personagem principal é uma pessoa anônima, e é colocada em diálogo com uma figura conhecida. No remix ${ }^{59} \mathrm{de}$ "Olá Marilene", do canal Viradrop ${ }^{60}$, o remixer inseriu o rosto da personagem no corpo de outra personagem, de um filme, que conversa com uma personagem interpretada pela atriz Jennifer Lopez, configurando um encontro romântico.

Figura 25: Trecho do remix "Olá, Marilene", do canal Viradrop

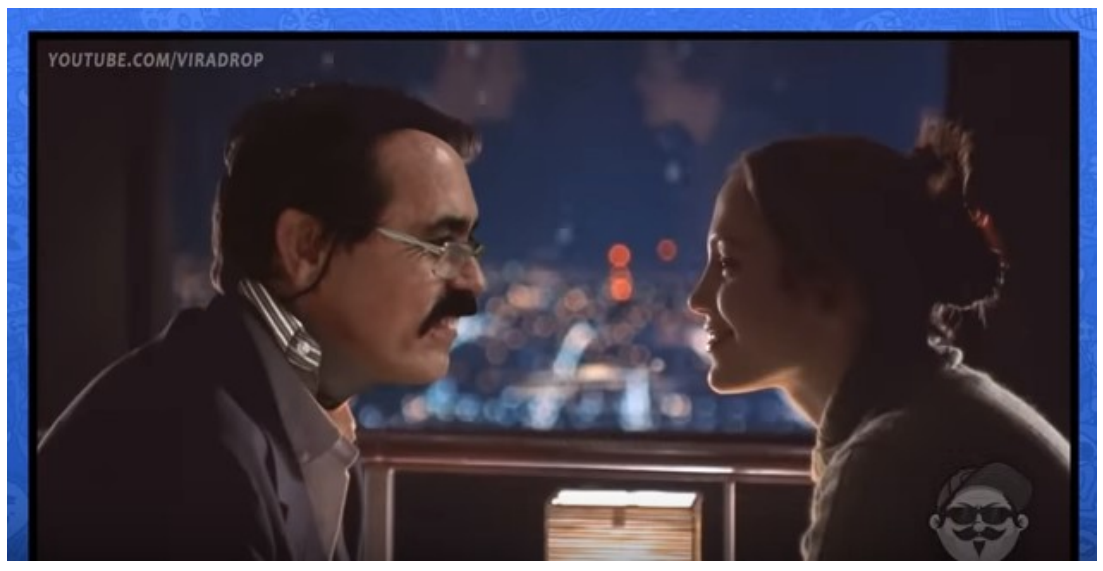

Fonte: https://www.youtube.com/watch?v=zn46nThk8Rw

Dada a simplicidade no acabamento da montagem, não é preciso conhecer o filme para entender que houve uma clara manipulação - o que esvazia a individualidade tanto da personagem principal quanto da outra, interpretada por Jennifer Lopez. A imagem se torna uma brincadeira de provocar coincidência a partir de elementos independentes. Coincidência e independência, segundo Bergson (1983), são recursos em potencial da comédia.

Ao fim desse mesmo remix, é incluída outra cena de filme, que mostra um jantar com várias pessoas. O telefone de uma delas toca, e quando atende, ouve-se a voz do homem (personagem principal), dizendo "Olá, Marilene". Momentos depois, alguém na mesa diz "por que não temos tainha no jantar?" (as falas são inseridas em legendas, como se fossem a tradução do diálogo). Essa colisão entre idiomas ressalta a independência entre os dois blocos, o que torna o arranjo incongruente.

59 Disponível em: https://www.youtube.com/watch?v=zn46nThk8Rw

600 remix foi feito a partir de um original que mostra uma entrevista de um homem sobre o dia dos namorados, que manda um recado para a tal Marilene, dizendo que à noite vai ter "tainha, vinho e muito sexo". 


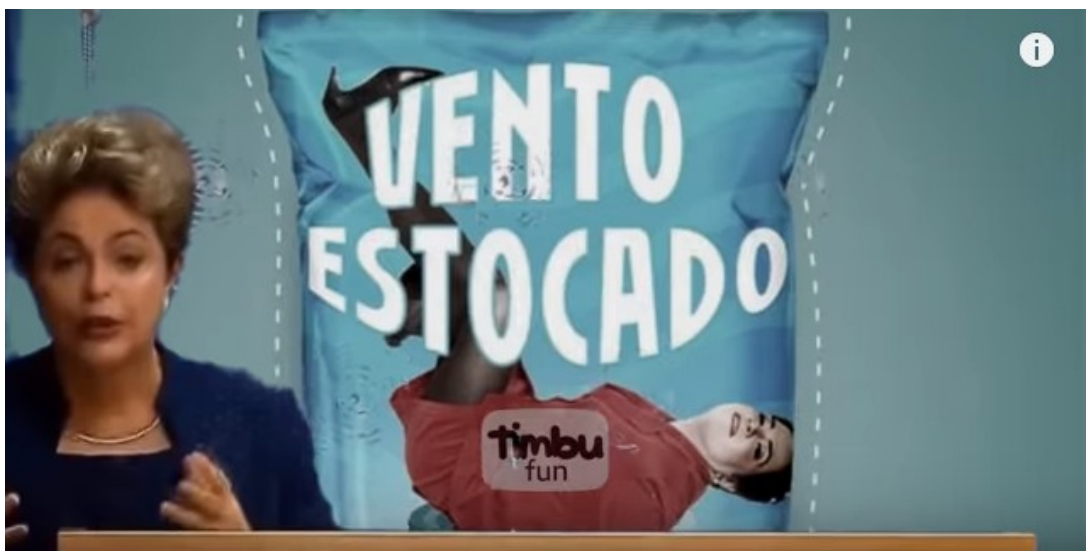

Fonte: https://www.youtube.com/user/Timbu Fun

Outro exemplo de expressão tomada em seu sentido literal é uma embalagem, que surge em meio ao remix de "Estocando o Vento", do canal Timbu Fun, com o rótulo "vento estocado", fazendo alusão ao discurso da personagem. Nos próximos subcapítulos veremos diversos outros exemplos de expressões tomadas "ao pé da letra", ou seja, materializando expressões conotativas. Percebemos, a partir disso, a relevância que o texto verbal tem para os remixers.

\subsection{Pelo deslocamento da personagem}

Há um tipo específico de coincidência por fala ou ação, que é no qual é a personagem principal que é inserida em outro espaço, externo ao original. No remix ${ }^{61}$ de "Senhora", do canal Timbu Fun, a ação mais relevante da personagem principal é correr. Ela, então, é inserida no cenário de um jogo eletrônico, como se pudesse ser controlada, sem autonomia. Esse tipo de bissociação ocorre pela lógica da imaginação, como vimos a partir de Bergson (1983). É possível observar uma ação, como a de correr, e se divertir imaginando-a em diversos cenários improváveis.

Assim como no subcapítulo anterior, o deslocamento também pode ocorrer por uma coincidência entre o que se diz e o que se vê, tomando uma metáfora como uma imagem literal. No remix ${ }^{62}$ de "Bambam Bodybuilder", do canal Atilakw, uma das personagens exclama "o monstro saiu da jaula!" e então vemos Bambam inserido dentro de uma jaula, por trás das grades.

61 Disponível em: https://www.youtube.com/watch?v=GdxPGO10fG4 62 Disponível em: https://www.youtube.com/watch?v=vfCozg8Yhxk 
A materialização de expressões em sentido literal ganha, mais uma vez, um exemplo no remix ${ }^{63}$ "Top", do canal Viradrop. Uma das frases que a personagem usa para exemplificar possíveis empregos da expressão "top" é "eu estava top no jantar no restaurante 'dovichicoso' (expressão incompreensível). Então, vemos a personagem em um carro, chegando em um local com uma placa escrito "Dove Chicoso".

Figura 27: Trecho do remix "Bambam Bodybuilder", do canal Atilakw

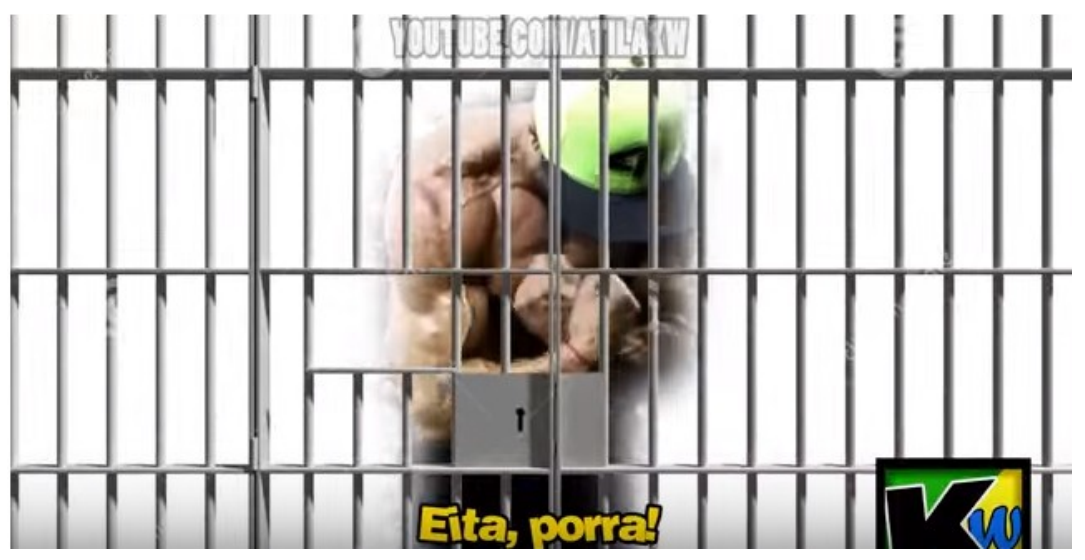

Fonte: https://www.youtube.com/watch?v=vfCozg8Yhxk

Figura 28: Trecho do remix "Top", do canal Viradrop

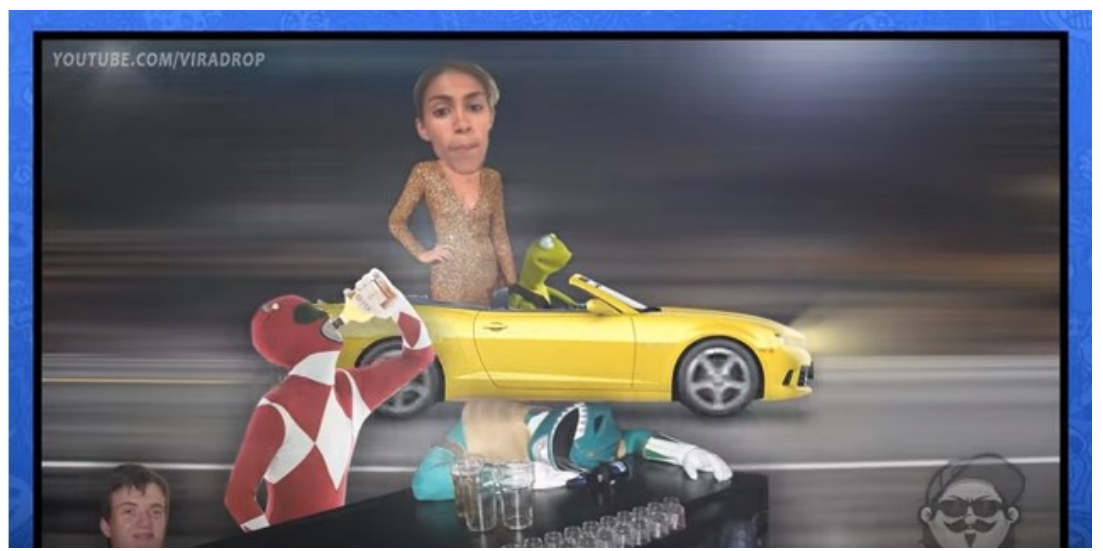

Fonte: https://www.youtube.com/watch?v=_SKG6edH3IM

Efeito semelhante pode se observar no remix ${ }^{64}$ "No céu tem pão?", do canal Viradrop, que parte de um original no qual o apresentador Renato Aragão, em uma transmissão do programa Criança Esperança, conta uma estória sobre uma criança que vai morrer de fome, e que pergunta se no céu tem pão. No início do remix, vemos uma cidade e no céu, o rosto gigante de Renato Aragão, uma colisão entre a personagem e uma imagem presente na estória que conta. O vídeo tem como tema o "céu", e a montagem situa a 
imagem do vídeo original no céu da cidade, como que ambientando o remix a partir de uma redundância inusitada.

Figura 29: Trecho do remix "O céu tem pão?", do canal Viradrop

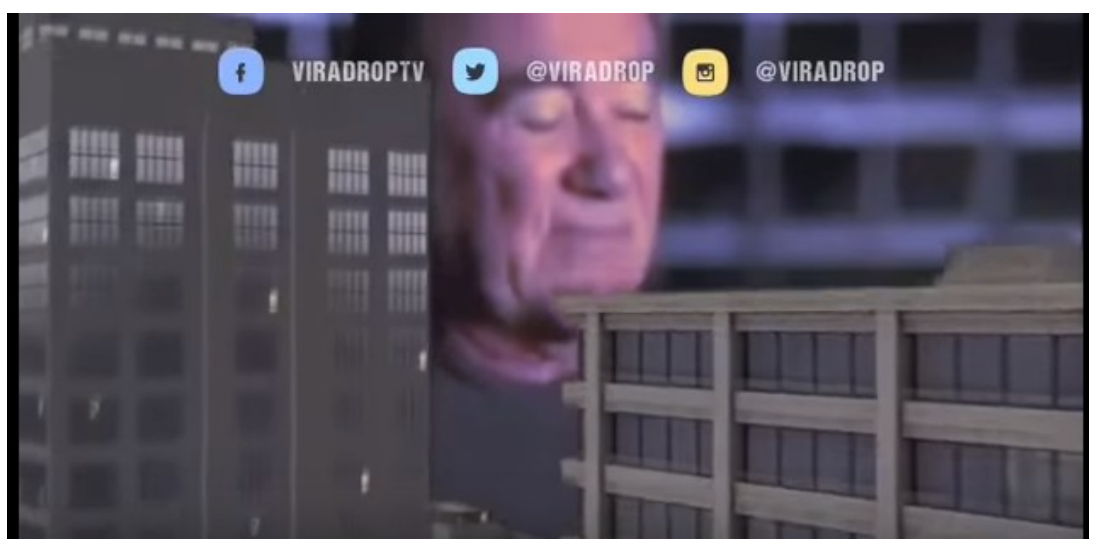

Fonte: https://www.youtube.com/watch?v=bL_-bWDtTvY

O canal Viradrop possui outros remix nos quais há a elaboração de um universo visual que representa algum aspecto do tema. Por exemplo, em "Morri", vemos um homem indignado porque "morreu" em um jogo de videogame. Essa personagem, então, é inserida dentro de um jogo eletrônico de luta, e é nocauteada. Nesse caso, além de se tomar a expressão em seu sentido literal, há a presentificação do corpo da personagem no universo que é o assunto de sua fala.

Figura 30: Trecho do remix "Seu buceta", do canal Viradrop

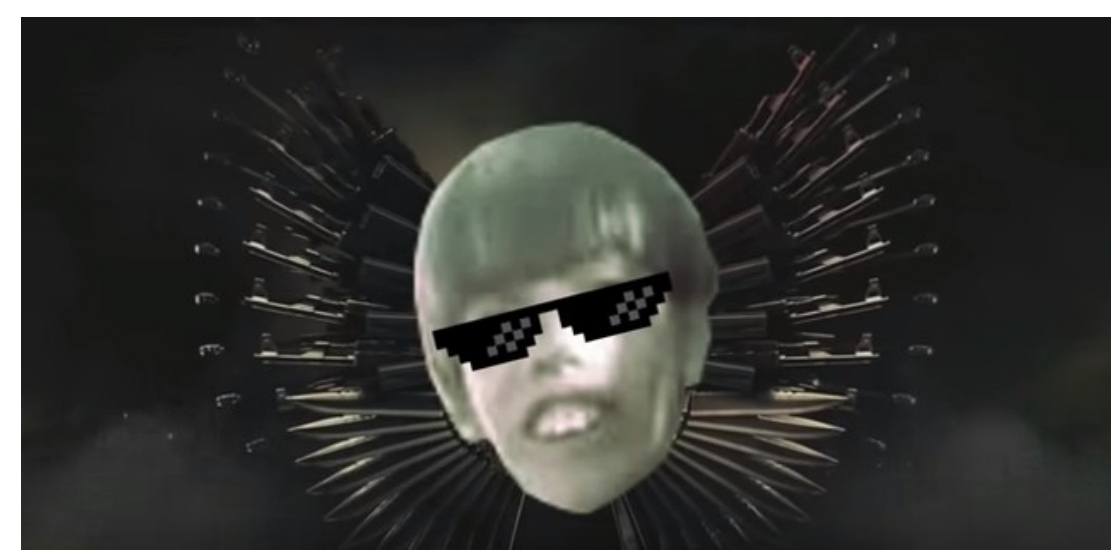

Fonte: https://www.youtube.com/watch?v=Sgacpd8zgJA\&t=17s

$\mathrm{O}$ assunto do original também pode ser expresso por meio de imagens abstratas e efeitos visuais que acompanhem o ritmo da música, normalmente espelhadas, criando efeitos caleidoscópicos. É o caso do remix ${ }^{65} \mathrm{de}$ "seu buceta", do canal Viradrop, no qual um menino diz vender armas. Então vemos essa personagem atravessar vários espaços abstratos, repletos de referências

65 Disponível em: https://www.youtube.com/watch?v=Sgacpd8zgJA\&t=17s 
visuais ligadas a armamento, como armas em efeito caleidoscópico, se tornando ornamentos em torno de seu rosto.

Figura 31: Trecho do remix de "Magrelinho", do canal Atilakw

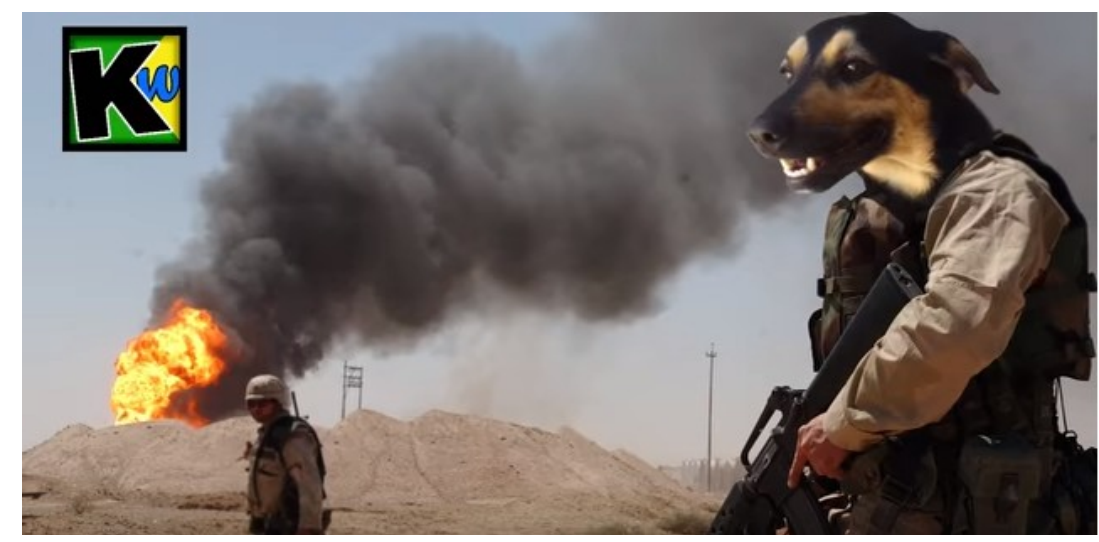

Fonte: https://www.youtube.com/watch?v=uIVEuZvlHsA

No remix ${ }^{66}$ de "Magrelinho", do canal Atilakw, vemos um rapaz que chora sobre o cadáver de seu cachorro recém-morto, que tinha como nome o título do vídeo. Então, vemos montagens que mostram Magrelinho vivo, vestindo roupas de soldado, em uma guerra. Essa inserção também é um exemplo de manipulação de sentido entre causa e efeito, pois há a sugestão de que o cachorro teria falecido durante uma guerra. Essa sugestão é colocada a partir da letra da canção, que diz "ele viajava, ele entrava pra guerra". Mais uma vez, uma expressão linguística tomada em seu sentido literal.

\subsubsection{Pelo encontro da personagem consigo mesma}

Em alguns casos, a mesma personagem possui mais de um vídeo na internet, de modo que é possível provocar a inserção da própria no remix, a partir de outro vídeo, coexistindo consigo mesma.

Há, por exemplo, o remix ${ }^{67 " E r r o u ”, ~ d o ~ C a n a l ~ V i r a d r o p, ~ n o ~ q u a l ~ a ~}$ personagem principal é o apresentador Faustão. Isso significa que antes de concluir a elaboração do trabalho, o remixer sabia que teria à sua disposição uma infinidade de vídeos dessa pessoa. Nesse caso percebemos que o diálogo da personagem consigo mesma é usado tanto no estabelecimento de coincidências - como em um trecho no qual vemos Faustão assistindo a si mesmo, em uma tela de notebook - como de incongruências - quando o rosto do apresentador é inserido também no corpo de um DJ, que anima uma grande festa de música eletrônica.

66 Disponível em: https://www.youtube.com/watch?v=ulVEuZviHsA 67 Disponivel em: https://www.youtube.com/watch?v=tRtb_fr6Sqg 
Figura 32: Trecho do remix "Errou", do Canal Viradrop

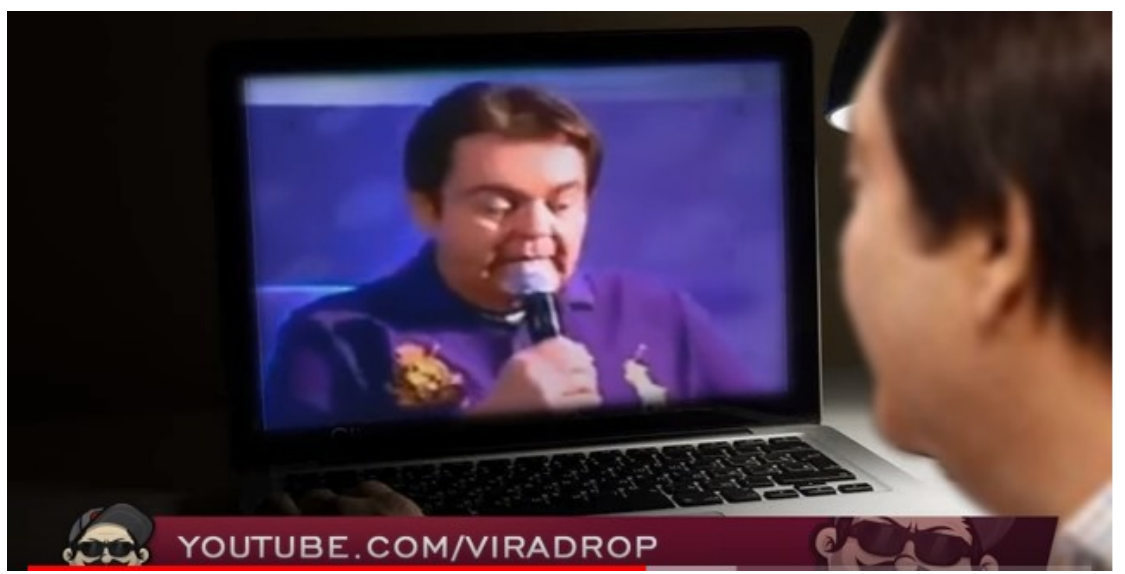

Fonte: https://www.youtube.com/watch?v=tRtb_fr6Sqg

Há também o exemplo de uma mesma personagem, anônima, que viralizou por dois vídeos diferentes, que estabelecem entre si uma contradição. É o caso do remix 68 "Nossa! (Milena Enem)". A mesma personagem deu duas entrevistas sobre o mesmo tema: em uma, ela fala sobre seus planos para o futuro, depois de passar no vestibular. $\mathrm{Na}$ outra, ela fala sobre ter perdido o horário para encontrar os portões abertos e realizar a prova do Enem. Nesse caso, o mote do vídeo é o jeito da menina de falar, associado à erva Cannabis - o que também é sugerido como causa para o fato de ela ter perdido a prova. Há, então, uma pequena narrativa: primeiramente, a moça fala sobre seus sonhos de futuro profissional - o que gera expectativa por um futuro a longo prazo. Em seguida, um desfecho patético.

Figura 33: Trecho do remix "Cepo de Madeira", do canal Timbu Fun

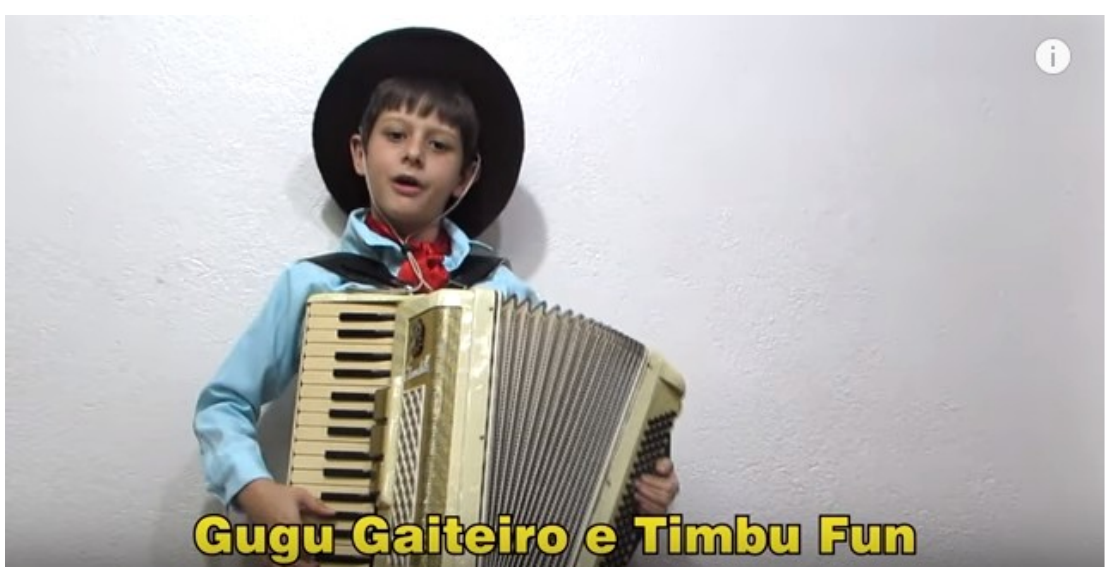

Fonte: https://www.youtube.com/watch?v=P6xnkFsx-sl

Outro exemplo no qual é utilizada mais de uma fonte para a mesma personagem ocorre no canal Timbu Fun, que conseguiu a façanha de gravar um vídeo inédito da personagem, com a finalidade de ser inserido no remix ${ }^{69}$. É 68 Disponível em: https://www.youtube.com/watch?v=g22sHJqBAFM 69 Disponível em: https://www.youtube.com/watch?v=P6xnkFsx-sl 
o que acontece em "Cepo de Madeira". Gugu gaiteiro surge com seu acordeom, ao fim do vídeo, executando a canção composta pelos remixers e agradecendo ao canal.

\subsection{Por reforço imagético da música}

Outro tipo bastante comum de inserção é o de personagens dançantes. Em se tratando e vídeos musicais, inserir imagens de dança pode ajudar o remix a ganhar dinâmica e assemelhar-se realmente com um vídeo musical. Muitas vezes são vídeos de origem pouco conhecida, mas que reforçam o estilo musical proposto, sendo colocados em concordância com o ritmo da canção. Os remix do canal Viradrop, por serem todos em acordes eletrônicos, costumam inserir, além de personagens que parecem dançar naquele ritmo, efeitos visuais caleidoscópicos, e spots de luzes coloridas.

Figura 34: Trecho do remix "Estocando o vento", do canal Timbu Fun

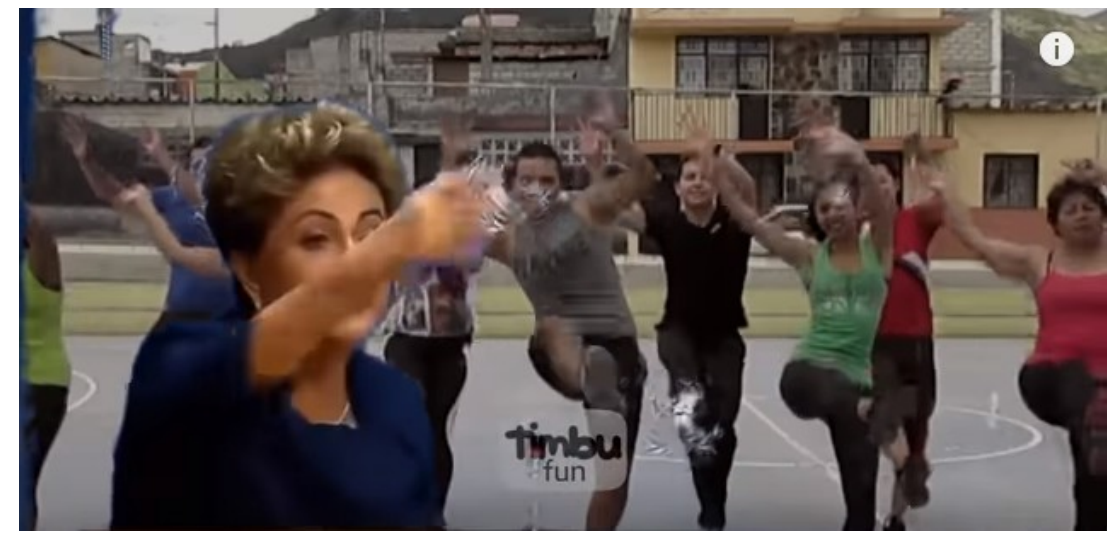

Fonte: https://www.youtube.com/watch?v=dhwsJxV4hs4\&t=42s

Um exemplo interessante do uso da dança está no remix ${ }^{70 " E s t o c a n d o ~}$ o Vento", do canal Timbu Fun. A personagem principal é a ex-presidenta Dilma Roussef, que no refrão, canta: "Cê joga de lá pra cá, de lá pra lá, de lá pra cá, de lá pra lá", enquanto gesticula com os braços. O fundo do vídeo foi apagado e foram inseridas pessoas dançando no ritmo da canção, que se assemelha a uma zumba.

Porém, as possibilidades em relação ao arranjo sonoro vão além da dança. Vejamos alguns exemplos: no arranjo musical do remix de "Bem Loco, Empolgante", do canal Timbu Fun, há um coral de fundo que acompanha a voz da personagem principal. Então, os remixers incluíram imagens de corais de homens e mulheres cantando seriamente, com livretos nas mãos.

70 Disponível em: https://www.youtube.com/watch?v=dhwsJxV4hs4\&t=42s 
Figura 35: Trecho do remix "Bem Loco, Empolgante", do canal Timbu Fun

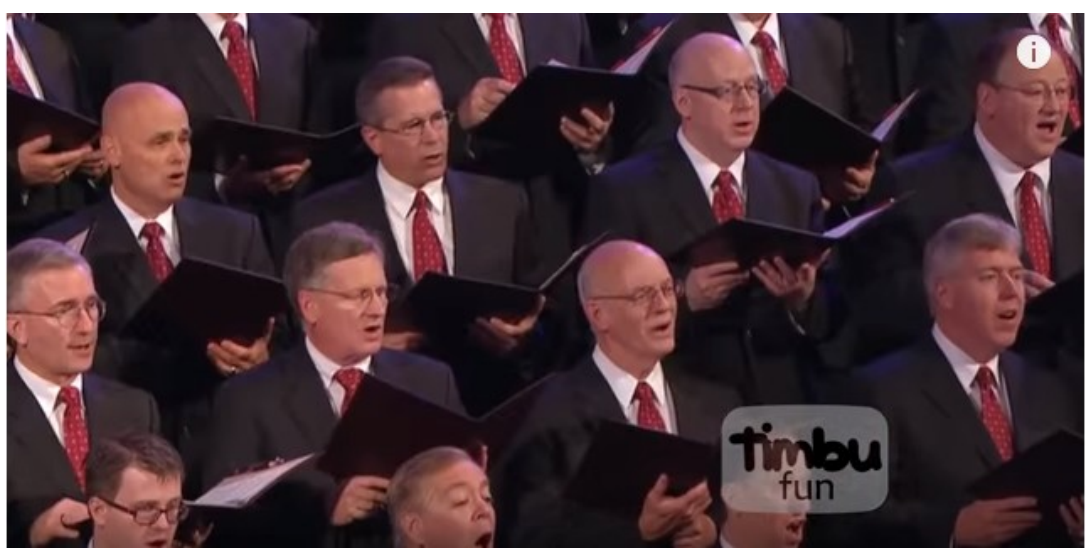

Fonte: https://www.youtube.com/watch?v=or4KcD8vVPs

O mesmo canal elaborou um remix ${ }^{71}$, intitulado "The Voice Dog", a partir de um original que mostra um cachorro que late em um timbre muito parecido com a voz humana. Esse é um exemplo de canção sem letra, já que se trata apenas de latidos de um cachorro.

Figura 36: Trecho do remix "The voice dog", do canal Timbu Fun

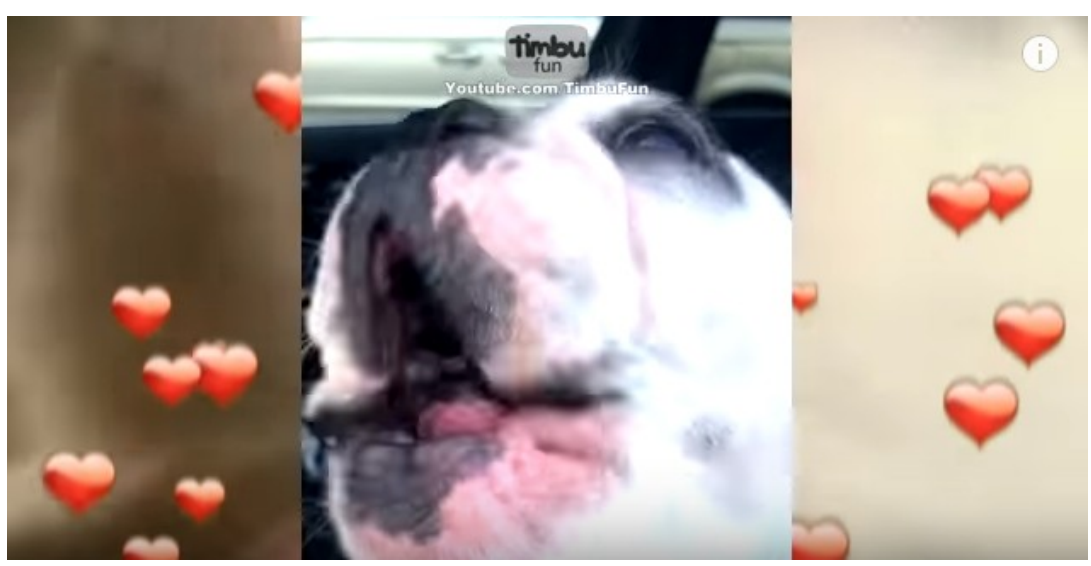

Fonte: https://www.youtube.com/watch?v=_RzsPdmfcaw

Contudo, nesse mesmo trabalho, os remixers inseriram um sample da música "I Will Aways Love You", da cantora Whitney Houston. Nesse caso, o sample extraiu somente a melodia e não o áudio original. Importante observar que tal música é conhecida não apenas pelo seu lirismo, mas por demonstrar a potência vocal da cantora. Ao deslocar esse fragmento para o contexto de um cachorro cantor, o remixer provoca o riso ao colocar em convívio os dois registros, provocando uma coincidência entre elementos aparentemente incompatíveis. A montagem propõe uma surpresa, revelando, por apenas um segundo, o rosto da cantora logo antes do início do sample, estabelecendo um estranhamento que se justifica no segundo seguinte. Durante o trecho em que

71 Disponível em: https://www.youtube.com/watch?v=_RzsPdmfcaw 
o cachorro canta Whitney, podemos ver subirem na tela ícones de coração, da mesma forma que no aplicativo Whatsapp.

Figura 37: Trecho do remix "Tu é louca", do canal Atilakw

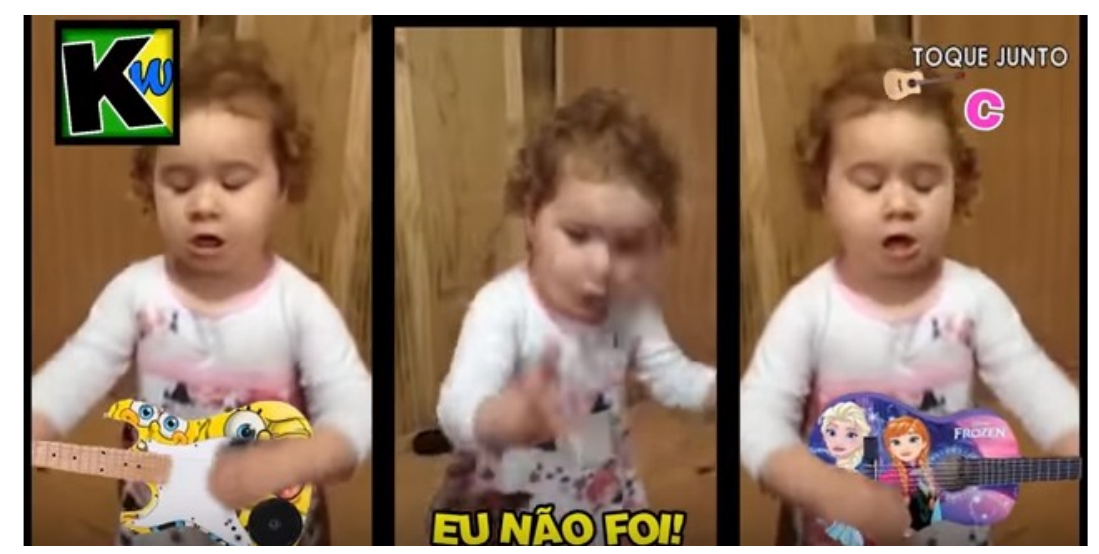

Fonte: https://www.youtube.com/watch?v=3u6_DAopIOM\&t=43s

Além da inserção de novos personagens e de efeitos de iluminação, como já comentamos, há também a inserção de instrumentos musicais. No remix ${ }^{72}$ de "tu é louca", do canal Atilakw, a personagem no vídeo original é uma criança - o que, por si só, já possui potencial cômico. Ela gesticula de modo que foi possível inserir artificialmente guitarras, estilizadas com imagens de desenhos animados. O mesmo canal, no remix "Galo Cego", conseguiu multiplicar o rosto da personagem nos corpos dos músicos de uma banda inteira. Efeito similar acontece no remix "Felipe Smith", no mesmo canal.

\subsection{Por coincidência entre personagens}

Percebemos que outro possível critério dos remixers para a escolha de novos personagens são certas semelhanças ou associações que se mostram possíveis entre os personagens principais e outros, externos ao vídeo original.

Já mencionamos a bissociação, por semelhança do timbre da voz, estabelecida entre as personagens de "Arrocha do Falsete", do canal Timbu fun, com animais e objetos. O mesmo canal, no remix "The Voice Dog", cuja personagem principal é um cachorro, insere no vídeo imagens de outros cachorros, que parecem dançar. Desse modo, temos a impressão de que o remix reforça a construção de uma semiosfera própria, de lógica interna singular, na qual ações em geral são executadas por cães, por semelhança com a personagem principal. Inclusive há um cão que "dança" sobre duas patas, como se estivesse rebolando - absorvendo características humanas e surpreendendo o espectador com sua aparição. Em geral, esse vídeo 72 Disponível em: https://www.youtube.com/watch?v=3u6_DAoplOM\&t=43s 
apresenta cachorros com comportamento e voz semelhantes aos de humanos, uma característica grotesca. Percebemos, portanto, que o grotesco, na internet, ocorre não somente pela aproximação do humano com o animal, mas também no vetor inverso, humanizando os bichos.

Outro exemplo de bissociação entre personagens pode ser encontrado no canal Viradrop. O remix ${ }^{73}$ "não sei" foi elaborado a partir de dois originais diferentes, unidos pela coincidência entre as atitudes dos personagens. Em ambos os vídeos, os personagens, ao cometerem crimes, são interrogados por repórteres e respondem, repetitivamente: "não sei". Temos, então, dois personagens cínicos, e é precisamente essa característica que os une.

Figura 38: Trecho do remix "Sé loco Cachuera", do canal Viradrop

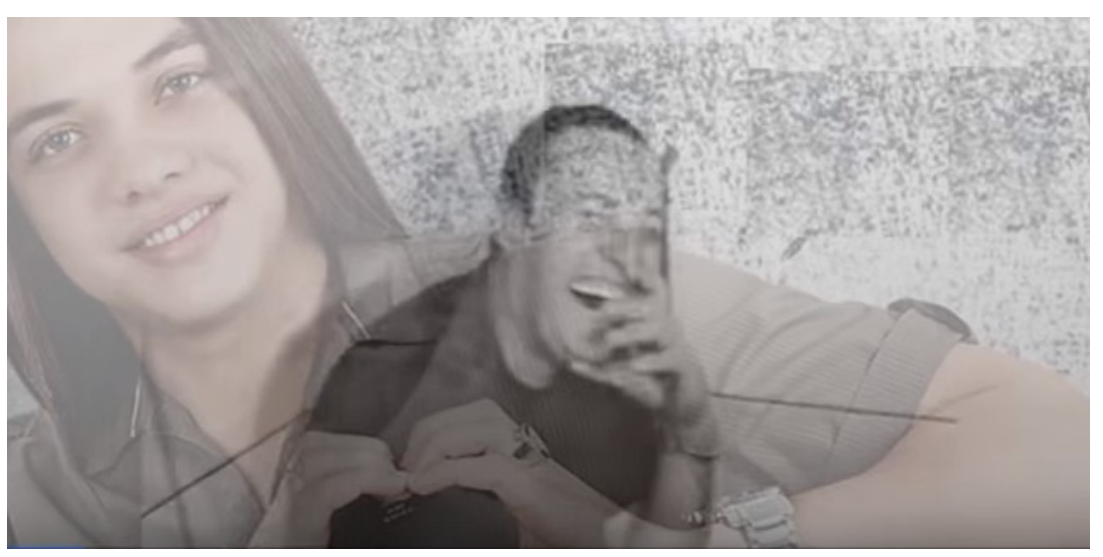

Fonte: https://www.youtube.com/watch?v=mXYCZLOAMwo

A associação entre personagens pode ter importância tal a ponto de fundamentar a criação do remix, como no último exemplo, mas também pode acontecer em pequenos repentes, piadas rápidas. Por exemplo, no remix ${ }^{74 “ S e ́ ~}$ loco Cachuera", do canal Viradrop, há um rápido momento em que a personagem afirma "eu sou Safadão", e então é inserida no quadro uma fotografia do cantor Wesley Safadão. Esse também pode ser entendido como um caso de coincidência a partir de fala.

Contudo, as bissociações estabelecidas a partir de personagens não se dão somente pelo nome próprio ou comportamento social. As escolhas podem ser inusitadas e surpreendentes, como no remix de "Choque da Uva", do canal Viradrop. Depois de sofrer o choque elétrico, vemos uma cena do seriado de animação japonês Dragon Ball Z, em que o protagonista Goku emana "energias" de seu corpo. A coincidência entre a personagem principal e

73 Disponível em: https://www.youtube.com/watch?v=Tvws21hiD-s 74 Disponível em: https://www.youtube.com/watch?v=mXYCZLOAMwo 
a externa está em uma característica física da personagem no momento do acontecimento.

\subsection{Como comentário}

Certos remix comentam o próprio vídeo. Por exemplo, em "Saudação à Mandioca", há a inserção de um macaco com a expressão de horror, logo depois que a ex-presidenta fala que existem "homo sapiens" e "mulheres sapiens". Recurso semelhante pode ser visto em "Sargento Fahur, do canal Viradrop. No vídeo, um sargento faz várias ameaças em tom agressivo contra traficantes. Entre uma fala e outra, são inseridos vários personagens diferentes, com expressão de susto.

Em alguns remix do canal Timbu Fun, também é exibido um trecho do videoclipe "Thriller", do cantor Michael Jackson, em um pequeno instante em que o cantor está no cinema, comendo pipocas e um olhar interessado. Essa imagem funciona como comentário para diversas situações, como que demonstrando que está acontecendo algum conflito interessante de se assistir.

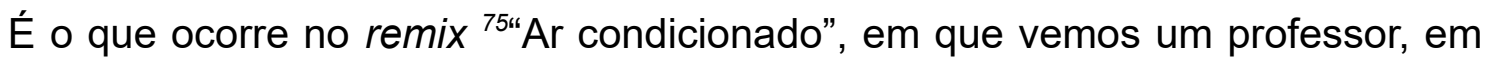
sala de aula, falando com os alunos com bastante agressividade.

O motivo da ação do professor no referido vídeo é a temperatura do refrigerador de ar durante a sua aula. Em alguns momentos do vídeo, é inserido um efeito hiperbólico de congelamento do espaço, e por uma fração de segundos, podemos ver a expressão de medo no rosto da personagem Elza, do filme Frozen, que se passa no gelo.

Figura 39: Trecho do remix "Ar condicionado", do canal Timbu Fun

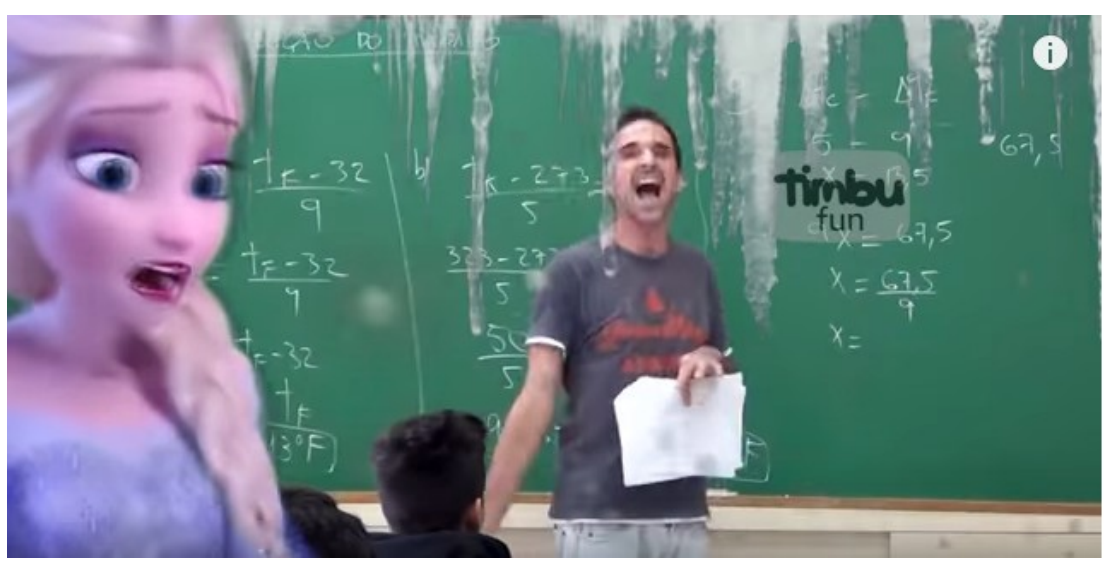

Fonte: https://www.youtube.com/watch?v=3yFAzFclBJE

75 Disponível em: https://www.youtube.com/watch?v=3yFAzFcIBJE 
Há outro exemplo curioso no remix 76 "No Céu Tem Pão", realizado pelo canal Atilakw. Em uma rápida aparição, Renato Aragão é interrompido por Zacarias, personagem da série "Os Trapalhões", com quem contracenou. Zacarias dá sua risada característica dizendo "Ai, Didi!". Nesse momento há uma colisão entre ator e personagem, uma coincidência de potencial cômico.

As possibilidades são diversas. Para exprimir estranhamento em meio a um contexto non-sense, o canal Viradrop, no remix de "Galo Cego" insere o ator Tom Cruise, que parece confuso, procurando algo no chão.

O comentário ocorre ainda pelo deslocamento da personagem principal, ou pela criação de outros espaços. É comum que, em alguns remix do canal Viradrop, as personagens principais sejam exibidas em telas, assistidas por outras personagens, que expressam estranhamento ou repulsa, como nos casos de "Bambam Enlouquecendo" e "Olá, Marilene".

Há ainda uma forma mais literal de o remixer comentar o próprio vídeo, que é se filmar e então se inserir dentro do próprio remix. O Canal Atillakw insere o próprio criador, em espaços do vídeo, tocando seus instrumentos, como que em uma imagem de "making off" incorporada à semiosfera do vídeo. No remix ${ }^{77}$ "Chama a Mamãe, Ketlyn", no qual as duas personagens estão sobre uma cama, podemos ver o próprio Atila sentado à beira da cama, tocando seu violão, olhando para as personagens e rindo. Sendo o riso um ato político, o autor da piada se presentifica, rindo da cena original, compartilhando com o espectador sua opinião e estimulando-o a rir também. Esse canal utiliza o mesmo recurso em outros remix, como "Fã do Raça Negra", "Galo Cego" e "Eu sou o Dougras".

Figura 40: Trecho do remix "Chama a Mamãe, Ketlyn", do canal Atilakw

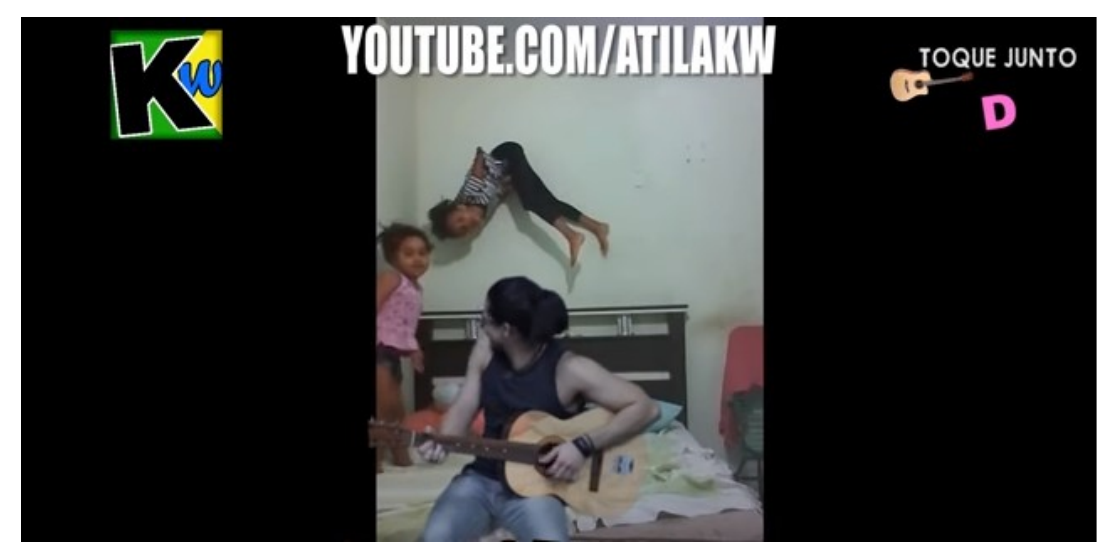

Fonte: https://www.youtube.com/watch?v=7_nbRgzyjl0

76 Disponível em: https://www.youtube.com/watch?v=AmvK4EdCrWE 77 Disponível em: https://www.youtube.com/watch?v=7_nbRgzyjl0 
Outro exemplo de comentário está em "Volta, querida"78, cuja letra não parte de nenhuma manipulação vocal, mas livre composição da dupla de remixers, que cantam "O Timbu Fun não é nada sem você", se referindo à expresidenta Dilma Roussef, após sofrer impeachment. A vemos em diferentes situações divertidas, em justaposição com imagens dos dois remixers sozinhos, em espaços amplos e aparentemente desamparados e tristes. Em uma das cenas, os dois aparecem deitados em um trilho de trem, como quem diz que a vida deixou de fazer sentido - uma atitude hiperbólica.

Consideramos que essas formas de comentário também nos aproximam do remixer, pois por meio desses recursos ele torna sua opinião presente na própria obra, mostrando como também se diverte. 


\section{CONSIDERAÇÕES FINAIS}

Compreendemos, a partir desta pesquisa, que a inserção e evolução de meios de comunicação alteram a vida das pessoas e sua cultura. Meios representam espaços públicos de convivência, nos quais ocorrem geração de valores, opiniões e compartilhamento de diversas representações da vida e do cotidiano. Por isso, consideramos relevante nos debruçarmos sobre o estudo do meio, não apenas como um plano técnico, mas uma articulação entre pessoas. Vimos que não são meros suportes tecnológicos, mas facilitadores de processos que impactam nossa cultura em escala global. A atividade do sampling, potencializada pelas tecnologias digitais e inserida na cultura atual é a força motriz dessa lógica, gerando novos discursos e dispositivos de criação.

Todos esses arranjos ocorrem simbolicamente no que chamamos de semiosfera, espaço virtual construído coletivamente, que opera com inteligência e memória, possibilitando diversas relações entre cultura e linguagem. Isso permite a organização do que conhecemos como inteligência coletiva: diversas pessoas se agrupam, utilizando a união de informações na resolução de problemas.

É importante lembrar que os meios também são influenciados pelas atividades sociais, em um diálogo de mão dupla, no qual a sociedade os altera enquanto estes também exercem influência sobre a cultura e as relações interpessoais.

A emergência do riso depende da cultura de cada lugar - por isso, algumas piadas surtem efeito em alguns países e em outros não. Pelo mesmo motivo, algo que é engraçado para um determinado grupo social pode não ser para outro do mesmo país. Visões de mundo e opiniões são articuladas na rede, que agrega pessoas em torno de ideias e imagens.

Levando isso em consideração, nos debruçamos, então, sobre uma amostra de obras contemporâneas que propõem um riso provocado por mediação tecnológica, ou seja, os vídeos remix com alteração de tempo e pitch na voz. Percebemos que esses vídeos se agrupam em torno de um template comum: todos apresentam curta duração, e em geral possuem como principal característica a criação de um music video a partir de um viral da internet.

Os softwares utilizados para esse efeito são o Auto-Tune e o Melodyne. Vimos que efeitos eletrônicos na voz são experimentados desde os meios 
analógicos, modelando formas de comunicação e de representação do humano diferenciadas, fazendo o timbre da voz se assemelhar ao de uma máquina.

Lançado como um software destinado a simplificar o trabalho de produtores musicais, o Auto-Tune teve sua função subvertida por usuários, que passaram a utilizá-lo como ferramenta cômica na elaboração de remix, em uma atitude irreverente, que consideramos carnavalesca.

Outra característica que esses remix possuem em comum foi a de serem publicados no YouTube, plataforma destinada à expressão pessoal, e que cada vez mais se configura como uma rede social. Neste ambiente, convive-se de forma local e global. Usuários são incentivados a se tornarem criadores, produtores de conteúdo, dispondo de diversas ferramentas online.

Esses novos produtores também são incentivados a gerir sua atividade, com acesso a gráficos que podem ajudar a atingir os públicos que pretendem. E mesmo aqueles que não produzem vídeos alimentam o site por meio de suas atividades: os vídeos que escolhem assistir, suas interações, comentários e reações deixam rastros que alimentam a formação de um banco de dados.

Percebemos, assim, a ocorrência do "bottom up", expressão que ilustra a "tomada de voz" de pessoas que, antes do advento das TIC, também tinham capacidade de interação e participação, mas com uma relação mais controlada entre emissor e receptor. O "descontrole" desse momento que vivemos é caracterizado pela retomada do Read-Writing (RW), modo de acesso à cultura no qual o usuário não apenas lê, mas também produz discurso, em um fluxo comunicacional bidirecional entre público e conglomerados de mídia, possibilitado pela liberação do polo da emissão. Hoje em dia, os "amadores" ocupam uma posição de fundamental importância na cultura audiovisual.

Ressaltamos, assim, que todas essas transformações não fizeram os meios tradicionais desaparecerem. A convergência dos meios é um dos pilares da "Cultura da Convergência". Meios tradicionais se adaptaram à era digital, operando em conjunto com os mais recentes. Os outros dois pilares são a inteligência coletiva e a cultura participativa.

O remix se dá por relações alegóricas que estabelece com a obra "original". De forma caótica, compreendemos um texto (original) a partir de sua conexão a outro (remix). Algo da "aura espetacular" do original é mantido, de forma que seja possível reconhecer a origem dos fragmentos ali utilizados, ou 
seja, a sua historicidade. Isso se dá por uma relação de hipermidiação, ou seja, pela consciência explícita que o espectador tem do processo de apropriação ocorrido.

Nosso intuito foi de compreender melhor, a partir desse recorte, como se dá a relação entre riso e tecnologia, nos perguntando de que modo (e se) a tecnologia altera nossas formas de rir. Para tal, optamos pelo recorte apresentado.

Sejam vídeos caseiros, de cinema ou televisão, as situações fazem parte de uma cultura de produção audiovisual que antes era restrita à grandes corporações de comunicação e hoje é respirada por um espectro social muito maior. Muitas pessoas passaram a ter acesso a tecnologias de captação e distribuição de áudio e vídeo, transformando essa cultura audiovisual ao apresentar formas diferentes, inusitadas e divertidas de conteúdo.

A partir de então, em nossa análise, buscamos compreender que aspectos do riso seriam específicos a esse recorte, ou seja, qual o potencial cômico de uma reelaboração de um vídeo viral que já seria considerado engraçado. Isso implicaria a criação de novas camadas de humor, específicas aos meios tecnológicos, portanto importantes para a compreensão de como o riso é afetado e encontra novos lugares com a tecnologia.

As razões que levam alguém a considerar um vídeo cômico são muitas, de modo que não é possível defini-las de forma precisa, mas sim farejar indícios de sua comicidade. Pode-se encontrar a hipérbole, que como vimos, é caracterizada pelo exagero, podendo ser para mais (aumentativa) ou para menos (diminutiva). Podemos encontrar outros aspectos de potencial risível, como as ocorrências do grotesco.

Foi surpreendente perceber, a partir do referencial teórico levantado nessa pesquisa, como o grotesco permanece presente na mídia brasileira. Não apenas na internet, mas na televisão, em programas de auditório, que simulam espaços de convívio espetaculares, com a exibição de brigas, incitação ao sexo, à violência e ao inusitado. O mesmo ocorre em reality shows, por exemplo.

Importante frisar que o grotesco não se dá somente pelo riso, mas também pelo espanto e pela repulsa, e então o leque de atrações midiáticas se torna muito maior: jornais policiais, testes de DNA e diversos meios de exposição da pobreza. 
Além disso, é preciso observar que em nossa cultura de comédia, é recorrente a ridicularização de camadas menos favorecidas socialmente. Por muitas vezes, o riso tem como alvo o pobre, o negro, o homossexual e outros grupos marginalizados. A cultura de exclusão desses grupos é refletida na construção das formas de rir pelas mídias tradicionais.

Outra surpresa que tivemos em meio à pesquisa foi perceber a atualização, pela internet, de um dos aspectos do grotesco: a animalidade, que no grotesco, ocorre pela aproximação do humano com o animal. Na Idade Média, isso ocorria por meio de representações de caráter corporal, físico, executada por humanos. O que nós fazemos em relação a isso atualmente é brincar com filmagens de animais, facilmente encontradas na database de nossa cultura audiovisual. O riso é intrinsecamente humano, mas podemos rir de animais se estes se comportarem de forma que lembre a humana: ingenuidade, frustrações, espontaneidade e insociabilidade. Dessa forma, a aproximação do humano com o animal, hoje, acontece com um vetor de sentido inverso.

Uma das formas de revelar o aspecto maquinal da estrutura social é se afastando do humano. Quanto mais se parecer uma coisa, maiores as chances de ser risível. É possível obter esse efeito anulando características individuais, que tornam um ser humano único, e fazê-lo parecer, cada vez mais, com "qualquer pessoa". Nesse sentido, a estereotipação é um forte recurso da comédia.

Acreditamos que a relevância deste trabalho reside na atualidade do tema proposto. O YouTube está em franco crescimento. Segundo estatísticas do próprio site, o número de horas de visualização de vídeos cresce $60 \%$ a cada ano. A produção de conteúdo independente no Brasil também é cada vez maior. Portanto, contribuir para a compreensão desse quadro, fenômeno ainda pouco estudado na área, é de fundamental importância para o meio científico, considerando que muitos desses mecanismos que a sociedade contemporânea tem como meios de entretenimento possuem também potencial para provocar uma intensa reconfiguração das relações culturais e econômicas da sociedade como um todo. 


\section{REFERÊNCIAS BIBLIOGRÁFICAS}

BAKHTIN, Mikhail. A Cultura Popular na Idade Média e no Renascimento: o contexto de François Rabelais. Tradução de Yara Frateschi Vieira. São Paulo/Brasília: Hucitec/Editora Universidade de Brasília, 2008.

BARBOSA, Rodrigo Miranda. A internet como meio de comunicação a partir dos estudos da Teoria do Meio. 2010. 173f. Dissertação (Mestrado em Comunicação) - Programa de Pós-Graduação em Comunicação da Universidade de Brasília, Brasília. 2010.

BENJAMIN, Walter. A Obra de Arte na Era de sua Reprodutibilidade Técnica. In: Magia e Técnica, Arte e Política. Ensaios Sobre Literatura e História da Cultura. Obras Escolhidas. Vol. 1. São Paulo, Brasiliense, 1994.

BERGSON, Henri. O Riso: ensaio sobre a significação do cômico. Zahar Editores, Rio de Janeiro, 2a Edição, 1983.

BOURRIAUD, Nicolas. Pós-produção: como a arte reprograma o mundo contemporâneo; tradução Denise Bottman. São Paulo: Martins Fontes, 2009.

BRENEZ, Nicole; CHODOROV, Pip. Cartografia do found footage. Revista Laika, São Paulo, v. 3, n. 5, jun. 2015. Disponível em: $<$ http://www.revistalaika.org/cartografia-do-found-footagenicole-brenez-e-pipchodorov>. Acesso em 05 de dezembro de 2016.

BURCH, Noel. Práxis do cinema. São Paulo: Perspectiva, 1969. CARRIĖRE, Jean-Claude. A linguagem secreta do cinema.

BURGUESS, Jean; GREENE, Joshua.Youtube e a Revolução Digital. São Paulo: Editora Aleph, 2009.

CAMPOS, Haroldo de. Ideograma : lógica, poesia e linguagem. São Paulo, Editora da Universidade de São Paulo, 1984.

CARONE, Modesto. Metáfora e Montagem. São Paulo, Perspectiva, Col. Debates, vol. 102, 1974

CAUQUELIN, Anne. Arte Contemporânea - uma introdução. Trad. Rejane Janowitzer. São Paulo: Martins Fontes, 2005.

CHION, Michel. Audiovisão. Lisboa, Texto\&Grafia, 2011.

DAWKINS, Richard. O Gene Egoísta; Tradução Geraldo H. M Florsheim Editora Itatiaia Limitada, Belo Horizonte/MG, 1979.

EISENSTEIN, Sergei. O sentido do filme. Rio de Janeiro: Jorge Zahar Ed., 2002.

FELINTO, E. Videotrash: o Youtube a cultura do "spoof" na Internet. In: Encontro da Compós (Associação Nacional dos Programas de Pós-graduação em Comunicação), 16., 2007. Anais Eletrônicos... Curitiba: Universidade 
Tuiuti do Paraná, 2004. Disponível em:

<www.compos.org.br/data/biblioteca_176.pdf>. Acesso em: 07 abr 2017.

FLICHY, Patrice (Org.) ; FERREIRA, Jairo (Org.) ; Amaral, Adriana (Org.) .

Redes digitais: um mundo para os amadores. Novas relações entre mediadores, mediações e midiatizações. 1. ed. SANTA MARIA: FACOS UFSM, 2016. v. 1. 284p .

FONTANELLA, Fernando Israel . O que vem de baixo nos atinge: intertextualidade, reconhecimento e prazer na cultura digital trash. In: XXXII Congresso Brasileiro de Ciências da Comunicação, 2009, Curitiba. Anais do XXXII Congresso Brasileiro de Ciências da Comunicação. Curitiba: Universidade Positivo, 2009.

HUTCHEON, Linda. Uma teoria da paródia: ensinamentos das formas de arte do século XX. Trad. Teresa Louro Pérez. Rio de Janeiro: edições 70, 1985.

JARAMILLO ARANGO, Julian. Homens, maquinas e homens-maquina: o surgimento da musica eletronica. 2005. 182 p. Dissertação (mestrado) Universidade Estadual de Campinas, Instituto de Artes, Campinas, SP.

JENKINS, Henry. Cultura da Convergência, 2. ed. São Paulo: Aleph, 2009.

LEADBEATER, Charles e MILLER, Paul. The Pro-Am Revolution: How Enthusiasts are Changing our Economy and Society, Londres, Demos, 2004.

LARIZZATTI, Dóris Sathler. Da Semiosfera à Ludusfera: por uma filosofia do jogo de linguagem na hipermídia. In: II Jornada Discente do PPGCOM ECA USP, 2011, São Paulo. Anais da II Jornada Acadêmica Discente do PPGCOM ECA USP. São Paulo: PPGCOM ECA USP, 2011. v. 01. p. 72-72.

LESSIG, Lawrence. Cultura Livre: Como a grande mídia usa a tecnologia e a lei para barrar a criação cultural e controlar a criatividade. São Paulo, Trama, 2005.

LESSIG, Laurence. Remix. Londres: Inglaterra Blumsburry Pbls, 2008.

LEMOS, André. Cibercultura. Tecnologia e vida Social na Cultura Contemporânea. Porto alegre: Sulina, 2002, segunda edição, 2004.

Cidade e Mobilidade. Telefones celulares, funções pós-massivas e territótios informacionais. Em: Matrizes. No 1, 2007.

. Lixo ou Luxo na Cibercultura? Origens e atualidades da cultura "digital trash". In PEREIRA, Vinícius A, (org.), Cultura Digital Trash: Linguagens, Comportamentos e Desafios. Rio de Janeiro, E-Papers, 2007, p. 142-8

LUCENTINI, Vanderlei B. ELECTROPERA: TRAJETÓRIAS SONORAS NA PERFORMANCE ART. Revista Refletir , v. 02, p. 1-12, 2016. 
MANOVICH, Lev. Database as a Symbolic Form. 1999(b). Disponível online: http://www.manovich.net.

. The language of new media. Cambridge: MIT Press, 2001

. The Practice of Everyday (Media) Life. 2008. Disponível online: http://www.manovich.net.

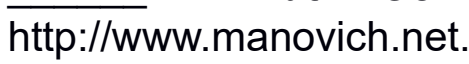

What Comes After Remix? 2007. Disponível online:

. Media After Software. Nova York, 2012(a). Disponível online: http://www.manovich.net.

MANSQUE, William. Conheça Gugu Gaiteiro, gauchinho que viralizou na web com o vídeo do "Cepo de Madeira". Gauchazh, 2017. Disponível online: https://gauchazh.clicrbs.com.br/comportamento/gente/noticia/2017/06/conhecagugu-gaiteiro-gauchinho-que-viralizou-na-web-com-o-video-do-cepo-demadeira-9825314.html

MARTINO, Luiz C. Contribuições para o estudo dos meios de comunicação. Revista FAMECOS: mídia, cultura e tecnologia, Porto Alegre, v. 1, n.13, p.103-114, dez. 2000.

MINOIS, Georges. História do riso e do escárnio. Tradução Maria Elena O. Ortiz. Assumpção. São Paulo: Editora UNESP, 2003.

NAVAS, E. Regressive and Reflexive Mashups in Sampling Culture. In: SONVILLA-WEISS, S. (Ed.). Mashup Cultures. Wien; New York: Springer, 2010. p. 157-177.

New York: Springer, 2012

Remix Theory: The Aesthetics of Sampling. Vienna;

NEGROPONTE, Nícolas. Vida digital. 2. ed. São Paulo: Companhia das Letras, 1995.

PARENTE, André. Tramas da Rede - Ed. Sulina, Porto Alegre, 2004.

PINHEIRO, Kelly Cristina Lourenço. Hipérbole como argumento retórico. Mediação, Belo. Horizonte, v. 15, n. 16, p. 149-167, jun. 2013. Disponível em: <http://www.fumec.br/revistas/index.php/mediacao/article/view/1374>. Acesso em: 15 mar. 2018.

SANTAELLA, Lúcia. Linguagens Líquidas na Era da Mobilidade. São Paulo: Paulus, 2007.

SANT'ANNA, Affonso Romano de. Paródia, paráfrase \& Cia, 7.ed. São Paulo: Ática, 2000.

SENNET, Richard. The craftsman. New Haven : Yale University Press, 2008. 
SODRÉ, Muniz; PAIVA, Raquel. O império do grotesco. Rio de Janeiro: Mauad, 2002.

STOROLLI, Wânia Mara Agostini. Poesia em movimento: entrelaçamento entre voz e tecnologia em Delusion de Laurie Anderson. Caderno de Resumos e Anais do XXV Congresso da ANPPOM: Formação de pesquisadores, docentes e artistas na área de musica: tendências, desafios e perspectivas., Vitória:ANPPOM, 2015

TIETZMANN, Roberto; ROSSINI, Miriam de Souza. O registro da experiência no audiovisual de acontecimento contemporâneo. Anais da XXII Compós, Bahia, 2013. Disponível em: <http://compos.org.br/data/biblioteca_1998.pdf> Acesso em 03 abr 2018.

VALCK, Marijke de; TEURLINGS, Jan. After The Break: Television Theory Today. Amsterdam University Press, Amsterdam, 2013.

XAVIER, Ismail. O discurso cinematográfico. A opacidade e a transparência. 3.ed. São Paulo: Paz e Terra, 2005.

\section{REFERÊNCIAS ONLINE:}

Canal da "Viradrop" no YouTube. Disponível em < https://www.youtube.com/channel/UCCjJ6nzg3-74FbISqmE_EcA/feed>. Acesso em 31/12/2016.

Canal da "AtillaKw" no YouTube. Disponível em < https://www.youtube.com/user/atilakw/>. Acesso em 31/12/2016.

Canal de "Timbu Fun" no YouTube. Disponível em < https://www.youtube.com/user/Timbu Fun>. Acesso em 31/12/2016.

Canal de "Schmoyolo" no Youtube. Disponível em <https://www.youtube.com/user/schmoyoho>. Acesso em 31/12/2016.

Site de Martha Gabriel. Disponível em <http://www.martha.com.br/umabrevissima-historia-do-meme/>. Acesso em 08/12/2016.

SOUZA, Claudio Manoel. Música Pop, E-music e Estudos Culturais. Disponível em: http://bocc.ubi.pt/pag/_texto.php3?html2=souza-manoelclaudiomusica-estudos-culturais.html. 2001 Acesso em: 5 de maio 2017. 